\title{
Double Arylation of the Indole Side Chain of Tri- and Tetrapodal Tryptophan Derivatives Renders Highly Potent HIV-1 and EV-A71 Entry Inhibitors ${ }^{\dagger}$
}

Olaia Martí-Marí, Belén Martínez-Gualda, Sofía de la Puente-Secades, Alberto Mills, Ernesto Quesada, Rana Abdelnabi, Liang Sun, Arnaud Boonen, Sam Noppen, Johan Neyts, Dominique Schols, María-José Camarasa, Federico Gago,* and Ana San-Félix*

Cite This: J. Med. Chem. 2021, 64, 10027-10046

Read Online

ABSTRACT: We have recently described a new generation of potent human immunodeficiency virus (HIV) and EV-A71 entry inhibitors. The prototypes contain three or four tryptophan (Trp) residues bearing an isophthalic acid moiety at the $\mathrm{C} 2$ position of each side-chain indole ring. This work is now extended by both shifting the position of the isophthalic acid to $\mathrm{C} 7$ and synthesizing doubly arylated $\mathrm{C} 2 / \mathrm{C} 7$ derivatives. The most potent derivative ( $50 \%$ effective concentration $\left(\mathrm{EC}_{50}\right) \mathrm{HIV}-1,6 \mathrm{nM} ; \mathrm{EC}_{50}$ EV-A71, $40 \mathrm{nM}$ ), 33 (AL-518), is a C2/C7 doubly arylated tetrapodal compound. Its superior anti-HIV potency with respect to the previous C2arylated prototype is in consonance with its higher affinity for the viral gp120. 33 (AL-518) showed comparable antiviral activities against X4 and R5 HIV-1 strains and seems to interact with the tip and base of the gp120 V3 loop. Taken together, these findings support the interest in $\mathbf{3 3}$

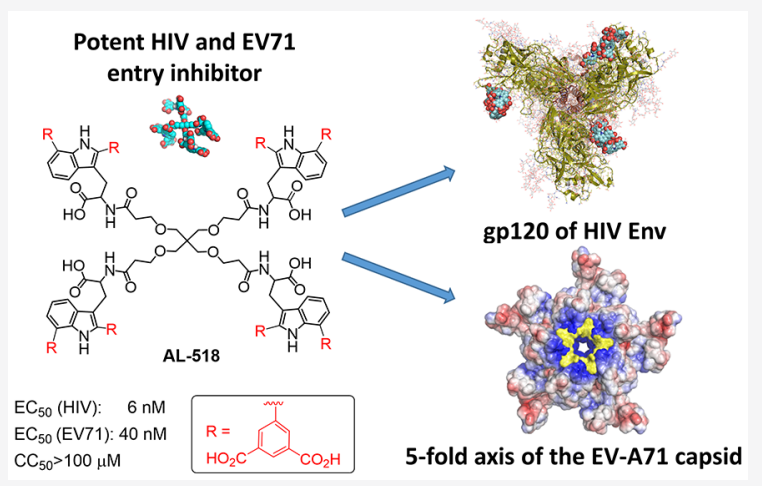
(AL-518) as a useful new prototype for anti-HIV/EV71 drug development.

\section{INTRODUCTION}

The entry of human immunodeficiency virus (HIV) into host cells is a complex multistage process mediated by the viral envelope (Env) spike glycoproteins gp120 and gp41. ${ }^{1-4}$ Each of the entry steps is critical in the HIV life cycle and consequently represents an attractive target for the development of new antiviral agents. ${ }^{5-10}$ In fact, compounds that interfere with these early steps have several advantages over other existing therapeutic approaches that target intracellular viral enzymes such as reverse transcriptase or protease. First, they may prevent healthy cells from being infected with HIV and thereupon block the spread of infection. Second, entry inhibitors have the advantage of acting before the virus is inside the cell, thus eliminating the need to cross the cell membrane. Finally, because of their distinct mechanism of action, entry/fusion inhibitors are likely to show remarkable efficacy against viruses resistant to other classes of antiretroviral drugs (e.g., reverse transcriptase, protease, and integrase inhibitors).

At present, four entry inhibitors have been approved by the Food and Drug Administration (FDA) for the treatment of HIV infection: enfuvirtide (T20), ${ }^{11}$ which targets the envelope glycoprotein gp41; maraviroc, ${ }^{12}$ which targets the host cell chemokine receptor type 5 (CCR5); ibalizumab, a novel anti-
CD4 monoclonal antibody (mAb), ${ }^{13,14}$ and fostemsavir (Rukobia), a prodrug of temsavir that has been very recently approved for the treatment of patients with HIV who cannot be treated with other therapies. ${ }^{15}$ This drug binds directly to gp120 and avoids the interaction between the virus and cellular CD4 receptors, thus preventing attachment. ${ }^{16}$

The Env glycoprotein gp120 is crucial for the HIV entry process because it serves as the first point of contact with the host cell's CD4 receptor prior to binding to the chemokine coreceptors, CCR5 or CXCR4, and subsequent triggering of the membrane fusion event. ${ }^{17,18}$ The third variable loop (V3) of gp120 is particularly important because it has been implicated in many viral functions, including coreceptor binding and determination of cell tropism. ${ }^{19}$ In fact, positively charged residues are frequently found at critical positions in the V3 loop in CXCR4-tropic viruses ${ }^{20}$ while neutral or negatively charged residues are found at these positions in

Received: February 19, 2021

Published: July 7, 2021 


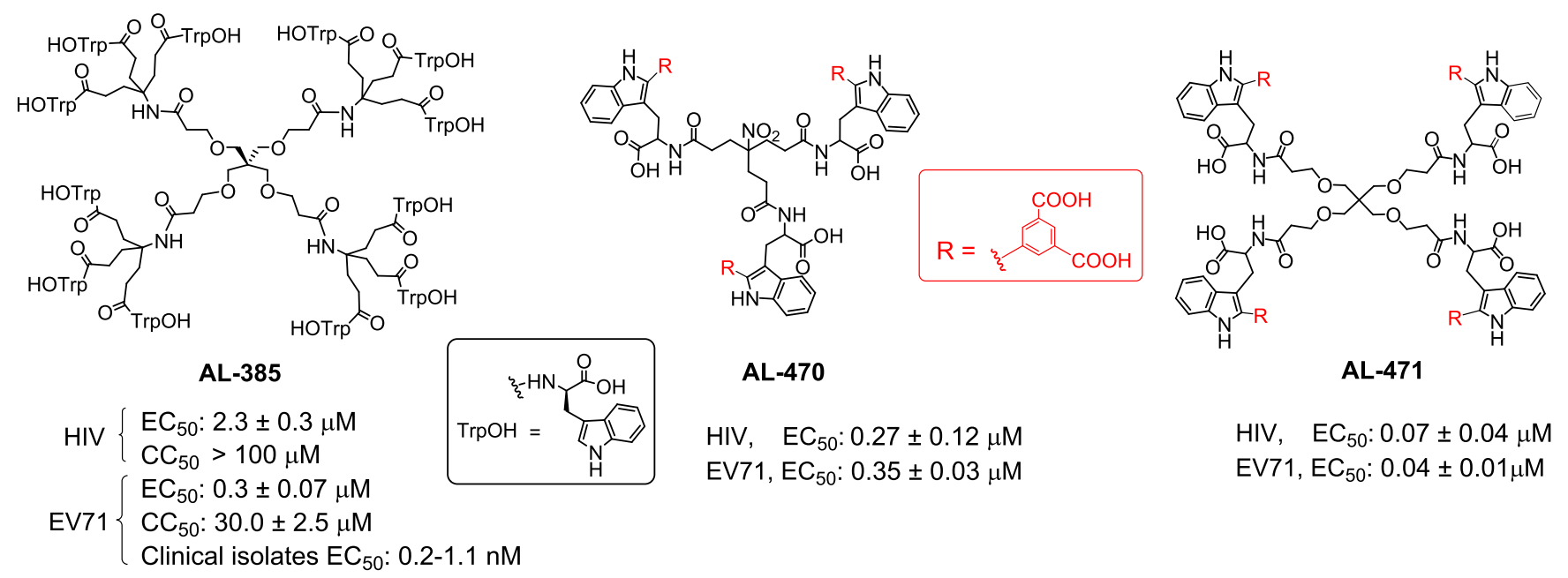

Figure 1. Structures of tetrapodal AL-385 and reduced size prototypes (tripodal AL-470 and tetrapodal AL-471).
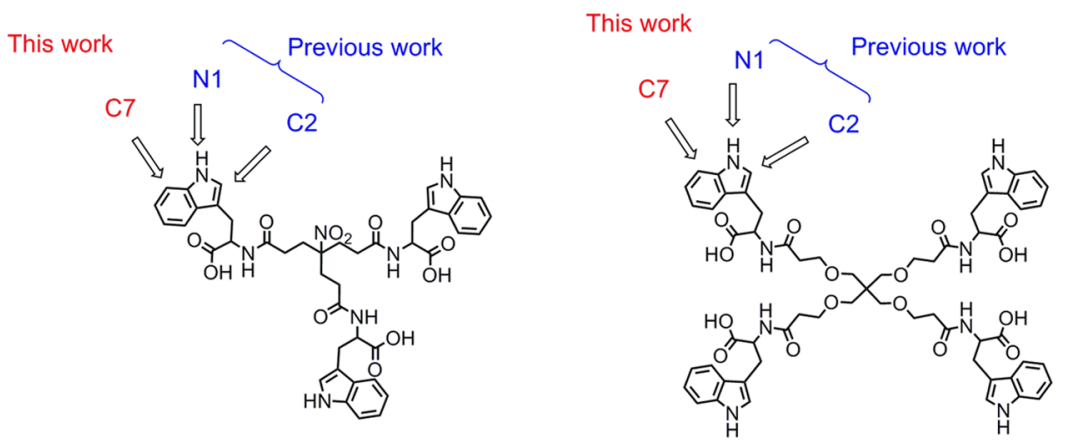

Figure 2. Indole positions explored for arylation in previous work (blue color) and in the present work (red color).

CCR5-tropic viruses. ${ }^{21}$ This loop is also a major antigenic determinant for inducing the formation of anti-HIV-1 antibodies. $^{22}$ For this reason, the V3 loop is considered an important candidate epitope for anti-HIV-1 vaccine design purposes.

Many broadly neutralizing antibodies (bnAbs) isolated from HIV-1-infected individuals target epitopes that combine hostderived glycans with Env components. ${ }^{23}$ Although the glycans serve to block much of the polypeptide surface from antibody recognition, they frequently become a target of recognition themselves. One of these epitopes is the so-called "V3-glycan supersite", an oligomannose patch around the V3 loop that is centered on the Asn332 residue. ${ }^{24}$ In this respect, structural studies have demonstrated that different bNAbs can adopt distinct binding orientations when targeting this supersite through specific interactions between residues in their complementarity-determining regions (CDR) and both polar and apolar faces of the sugar rings, which vary from complex to complex regarding density, clustering, and conformation of the constituent glycans. ${ }^{25}$

These observations raise the prospect that similar intermolecular interactions, namely, ring stacking and hydrogen bonds, can be achieved by means of (i) flat surfaces such as those provided by indole and phenyl rings and (ii) hydrogenbond acceptors such as carboxylic acids. Building on these premises, we have previously reported that a family of tri- and tetrapodal tryptophan (Trp) derivatives inhibits an early step in the infection of HIV by interacting with gp120 and preventing cell entry. ${ }^{26}$ The prototype is AL-385, which displays 12 Trp moieties attached to a tetrapodal central scaffold via their amino groups (Figure 1). Remarkably, these molecules also block entry of EV71, ${ }^{27}$ a completely unrelated neurotropic enterovirus that causes serious health problems in children under 5 years of age. ${ }^{28-32}$ In the last two decades, the increasing number of EV71 cases and the spread of the virus across Asia, followed by case reports in different European countries, raised major concerns about its pandemic potential. $^{33-35}$ Because no antiviral therapies are so far available for the prevention or treatment of EV71 infection, the development of effective and specific antiviral drugs is urgently needed. ${ }^{36,37}$

Using a scaffold simplification strategy, we recently described a second family of Trp derivatives of reduced size and dual anti-HIV and anti-EV71 activity. ${ }^{38}$ Representative prototypes of this second family are the tripodal AL-470 and tetrapodal AL-471 derivatives, which contain either three or four Trp residues, respectively, each bearing an isophthalic acid moiety at the $\mathrm{C} 2$ position of the indole ring (Figure 1). By a surface plasmon resonance (SPR) assay, we have demonstrated that the anti-HIV potency of both compounds is related to their interaction with gp120. ${ }^{38}$ Moreover, cross-resistance experiments, followed by cryo-electron microscopy (cryo-EM) and computer-assisted modeling studies, revealed that AL-471 interacts with the fivefold axis of the EV-A71 capsid, in particular with VP1 residues Lys244 (K244) and Tyr245 (Y245). ${ }^{38}$ Thus, binding of AL-471 to this region prevents the interaction of the virus with its cellular (co)receptors P-selectin glycoprotein ligand-1 (PSGL-1) and heparan sulfate, thereby 
Scheme 1. Synthesis of C7 Organoboron 3 and Arylated Trp Intermediates 7-9<smiles>CCCCNC(Cc1c[nH]c2ccccc12)C(=O)O</smiles><smiles></smiles>
$[\operatorname{lr}(\operatorname{cod}) \mathrm{OMe}]_{2}, \mathrm{dtbpy}$ THF anh. $60^{\circ} \mathrm{C}$<smiles>[R]c1cccc(-c2cccc3c(CC([NH3+])C(=O)OC)c[nH]c23)c1</smiles>

7, R: 3-COOMe (quant.) 8, R: 4-COOMe (quant.) 9, R: 3,5-COOMe (quant.)<smiles>COC(=O)NC(Cc1c(Cc2ccccc2)[nH]c2c(Cc3ccccc3)cccc12)C(=O)OCc1ccccc1</smiles>

2

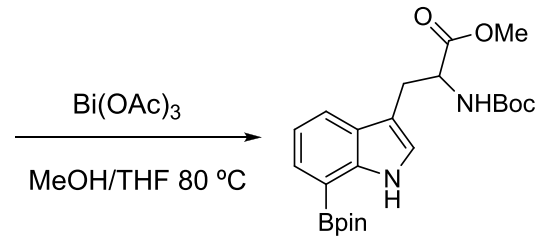

$3(47 \%)$
TFA, $\mathrm{CH}_{2} \mathrm{Cl}_{2}$

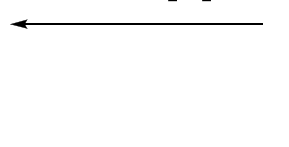<smiles>[R]c1cccc(-c2cccc3c(CC(NC(C)(C)C)C(=O)OC)c[nH]c23)c1</smiles><smiles>[R]c1ccc(Br)cc1</smiles>

$\mathrm{Pd}_{2}(\mathrm{dba})_{3}$, SPhos, $\mathrm{K}_{3} \mathrm{PO}_{4}$ Toluene anh., $80^{\circ} \mathrm{C}$

4, R: 3-COOMe (70\%)

5, R: 4-COOMe $(70 \%)$

6, R: 3,5-COOMe (56\%)

Scheme 2. Synthesis of C7-Arylated Tripodal (14-16) and Tetrapodal (21-23) Derivatives

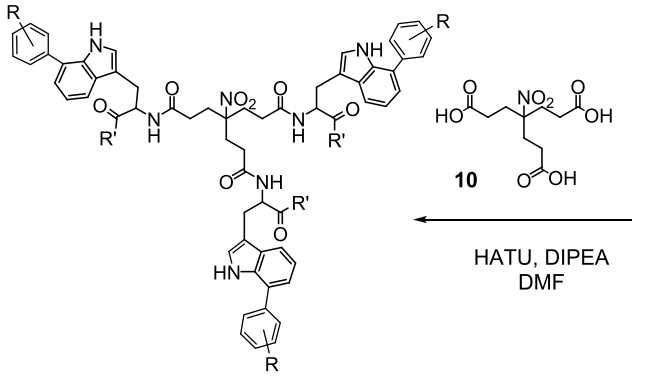

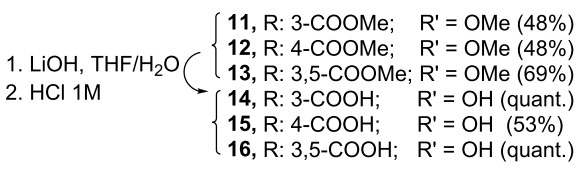

blocking the attachment of EV-A71 to the host cells. These results highlighted the promising potential of AL-470 and AL471 as lead compounds for further development of novel HIV and EV71 entry inhibitors that could also be potentially active against other viruses that share common structural features in their capsids.

Preliminary structure-activity relationship (SAR) studies on the series encompassing AL-470 and AL-471 prototypes demonstrated that the presence of extra phenyl rings bearing one or two carboxylates at the $\mathrm{C} 2$ position of the indole ring of each Trp residue is critical for anti-HIV/EV71 activity. In stark contrast, this type of substitution at the N1 position of the indole moiety led to a substantial decrease of anti-HIV/EV71 efficacy. Incidentally, placing phenyl rings with substituents other than $\mathrm{COOH}$ at positions $\mathrm{N} 1$ or $\mathrm{C} 2$ led to inhibitors of dengue and Zika virus infection that also interfere with viral attachment processes. ${ }^{39}$

The global aim of the present work was to expand the previous SAR studies by exploring other positions of the sidechain indole of Trp, different from $\mathrm{C} 2$ or N1, for introducing the crucial carboxyl-containing phenyl rings. To this end, position C7 was chosen (Figure 2), and the impact of this novel structural modification on the anti-HIV and anti-EV71 activities was investigated.

\section{RESULTS AND DISCUSSION}

Chemistry. For the synthesis of the C7-arylated compounds, a novel chemical approach consisting of several sequential steps was followed (Schemes 1 and 2). First, the C7arylated Trp derivatives 7-9, with a free amino group, were obtained (Scheme 1). Thereafter, these key intermediates were linked to the corresponding central scaffold (Scheme 2). Selective C7 arylation of Trp to afford the C7-arylated Trp derivatives 7-9 proved to be particularly challenging due to the lesser reactivity of the C7 position compared to the inherently greater reactivity of the azole C2 position. Several methods, based on metal-catalyzed $\mathrm{C}-\mathrm{H}$ boronation, have been envisaged to meet this end. ${ }^{40}$ Of particular relevance to this work was a two-step methodology developed by Movassaghi-Smith-Maleczka that involves the synthesis of the C7-boronated Trp derivative 3 (Scheme 1). ${ }^{41,42}$ This route started with the commercially available N-Boc-Trp methyl 
Scheme 3. Synthesis of C2/C7-Diarylated Tripodal (31) and Tetrapodal (32, 33) Derivatives

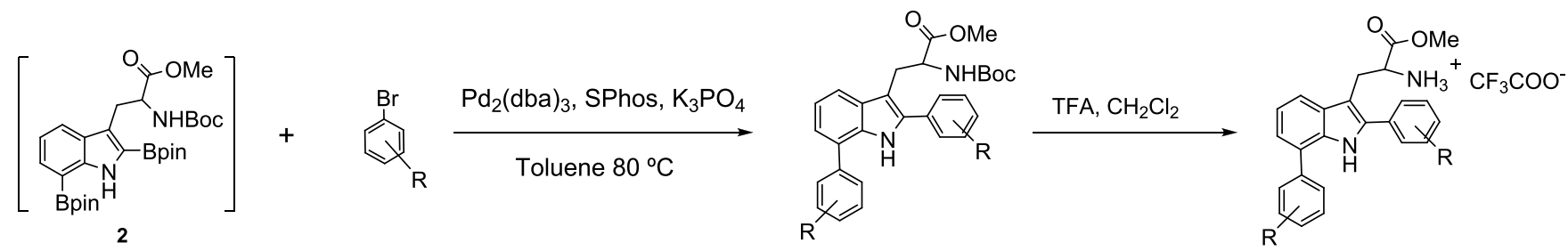

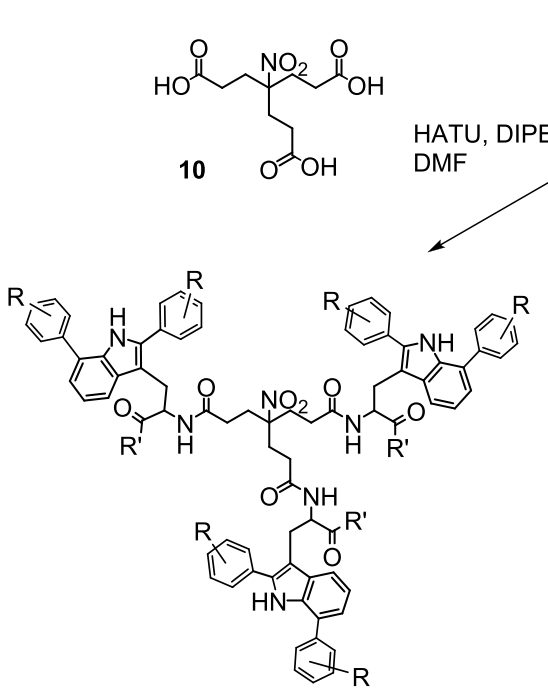

1. $\mathrm{LiOH}, \mathrm{THF} / \mathrm{H}_{2} \mathrm{O}$ (28, R: 3,5-COOMe; R' = OMe (88\%) 2. $\mathrm{HCl} 1 \mathrm{M}$<smiles>O=C(O)COC(COCCO)(OCCO)OCC(O)O</smiles>
only with 27

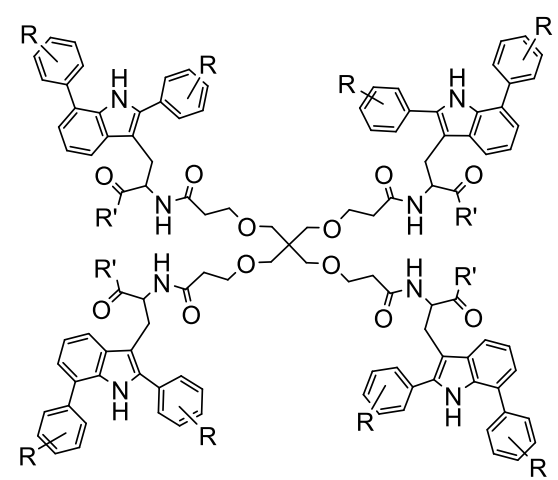

Scheme 4. Synthesis of (C2/C5/C7)-Triarylated Trp Derivative 37

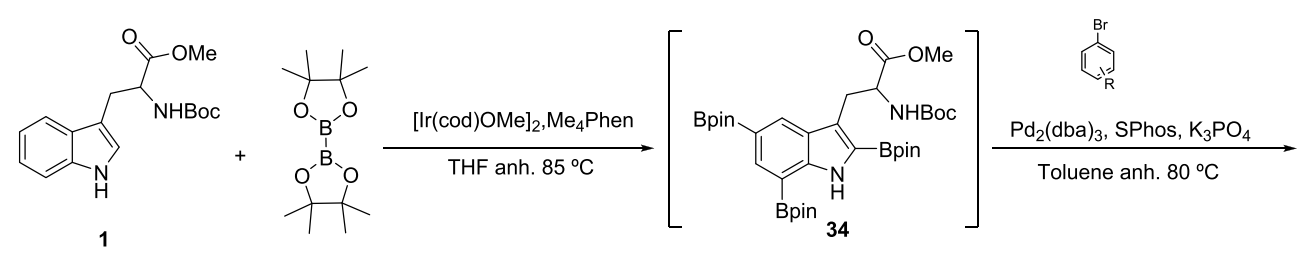<smiles>[R16][R16](=O)O[Na]</smiles>

TFA, $\mathrm{CH}_{2} \mathrm{Cl}_{2}$

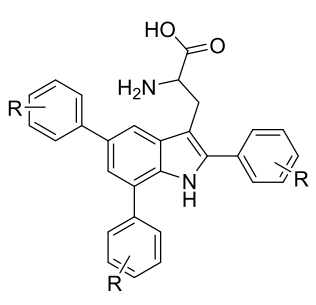

37, R: 3,5- $\mathrm{COOH}(76 \%)$
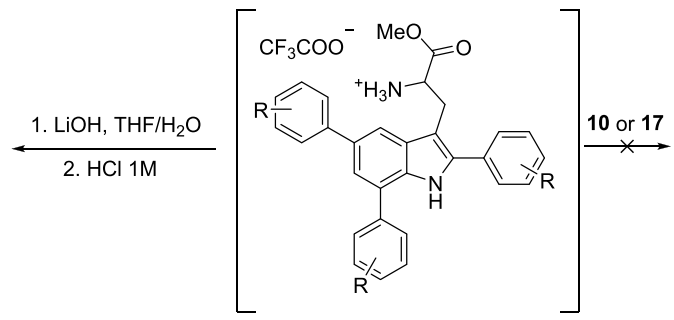

36, R: 3,5-COOMe ester $\mathbf{1}$. The first synthetic step consisted of diboronation of $\mathbf{1}$, which proceeded smoothly $\left(60{ }^{\circ} \mathrm{C}, 12 \mathrm{~h}\right)$ under iridiumcatalyzed conditions to afford the $\mathrm{C} 2 / \mathrm{C} 7$ diboronated intermediate 2 . In our hands, $\mathbf{2}$ was obtained more efficiently when bis(pinacolate)diboron $\left(\mathrm{B}_{2} \mathrm{pin}_{2}\right)^{43}$ was used in place of pinacolborane (HBpin) $)^{41}$ (Scheme 1$)$. The second step 
involved selective $\mathrm{C} 2$ protodeboronation of the crude product 2 in the presence of bismuth acetate as the catalyst to afford the 7-borylated Trp derivative 3 in $47 \%$ yield. ${ }^{41}$ Mild reaction conditions, under bismuth acetate catalysis, were crucial to avoid the formation of complex mixtures and simultaneous elimination of the $N$-Boc-protecting group that was observed when acetic acid was used in place of bismuth acetate.

Next, a Suzuki-Miyaura reaction (SMR) ${ }^{44}$ involving the coupling of organoboron $\operatorname{Trp}$ intermediate $3^{41}$ to the corresponding aryl bromide using $\left(\mathrm{Pd}_{2}(\mathrm{dba})_{3}\right)$ as the palladium catalyst and SPhos at $80{ }^{\circ} \mathrm{C}$ in the presence of potassium phosphate $\left(\mathrm{K}_{3} \mathrm{PO}_{4}\right)$ as the base afforded $\mathrm{C} 7$ aryl intermediates 4-6 in good yield (56-70\%) (Scheme 1). Aryl bromides bearing only one carboxylic acid substituent at the meta $(m-\mathrm{COOH})$ or para position $(p-\mathrm{COOH})$ or two carboxylic acid substituents at positions 3 and 5 on the aromatic ring were used because previous work had shown that this type of substituents renders the most potent compounds. ${ }^{38}$ Subsequent NHBoc deprotection afforded intermediates 7-9, with a free amino group, in quantitative yields. Thereafter, coupling of these amino intermediates 7-9 to the tripodal $(\mathbf{1 0})^{45}$ or tetrapodal $(\mathbf{1 7})^{46,47}$ central scaffolds afforded tripodal 11-13 and tetrapodal 18-20 derivatives, respectively (Scheme 2). Finally, saponification of the methyl ester groups $\left(\mathrm{LiOH} / \mathrm{H}_{2} \mathrm{O}\right)$ furnished the desired tripodal and tetrapodal end products 14-16 and 21-23, respectively, in high yields (Scheme 2).

Doubly arylated Trp intermediates $\mathbf{2 4}$ and $\mathbf{2 5}$ were obtained through an SMR between the crude C2/C7 diboronated intermediate $\mathbf{2}$ and two different aryl bromides (Scheme 3). Subsequent removal of the Boc-protecting group and coupling of the resulting amino intermediates $\mathbf{2 6}$ and $\mathbf{2 7}$ to the tripodal $(\mathbf{1 0})^{45}$ or tetrapodal $(\mathbf{1 7})^{46,47}$ cores afforded 28 and 29, 30, respectively. Methyl ester saponification afforded the desired final C2/C7-arylated tripodal (31) and tetrapodal (32, 33) derivatives in high yields.

To complete the SAR study, we decided to synthesize and test a triply arylated Trp derivative whose obtention would be accomplished through a convergent synthetic strategy similar to that described above (Scheme 4). The key intermediate in this route was triply arylated $\operatorname{Trp}$ derivative 35 , which was obtained through an SMR between the crude organoboron Trp intermediate $34,{ }^{48}$ bearing three Bpin substituents at the $\mathrm{C} 2 / \mathrm{C} 5 / \mathrm{C} 7$ positions, and isophthaloyl bromide. Subsequent removal of the Boc-protecting group afforded amino intermediate 36. Coupling of this compound to the tripodal $(\mathbf{1 0})^{45}$ or tetrapodal $(\mathbf{1 7})^{46,47}$ central scaffolds was unsuccessful, probably due to steric hindrance. Instead, full methyl ester deprotection was performed to give functionalized Trp derivative 37.

All of the final compounds had purities $>95 \%$ based on highperformance liquid chromatography (HPLC), liquid chromatography/mass spectrometry (LC/MS), and ${ }^{1} \mathrm{H}$ NMR analyses.

Antiviral Evaluation. Activity against EV71. First, the C7arylated tripodal (14-16) and tetrapodal (21-23) derivatives, together with their $\mathrm{C} 2 / \mathrm{C} 7$ doubly arylated counterparts $(31-$ 33 ) and the $\mathrm{C} 2 / \mathrm{C} 5 / \mathrm{C} 7$ triply arylated $\operatorname{Trp}$ derivative 37 , were evaluated for their in vitro inhibitory activity against EV-A71 (Table 1). The previously described prototypes (AL-470, AL471, and AL-385) (Figure 1), as well as pirodavir, an entry inhibitor that interacts with the viral capsid, were also assayed under the same conditions for comparative purposes. ${ }^{49,50}$
Table 1. Antiviral Activity of the Synthesized Compounds against the BrCr Lab Strain of EV-A71 in RD Cells ${ }^{a}$

$\begin{array}{llcl}\text { compound } & \mathrm{EC}_{50}(\mu \mathrm{M})^{b} & \mathrm{CC}_{50}(\mu \mathrm{M})^{c} & \mathrm{SI}^{d} \\ \mathbf{1 4} & 54.8 \pm 34.1 & >84 & 1 \\ \mathbf{1 5} & 61.6 \pm 25.1 & >61 & 1 \\ \mathbf{1 6} & 1.2 \pm 0.2 & >75 & 63 \\ \mathbf{2 1} & 3.1 \pm 1.1 & >61 & 20 \\ \mathbf{2 2} & 1.7 \pm 0.4 & >100 & 60 \\ \mathbf{2 3} & 0.3 \pm 0.04 & >55 & 157 \\ \mathbf{3 1} & 0.2 \pm 0.03 & >100 & 526 \\ \mathbf{3 2} & 0.1 \pm 0.02 & >100 & 667 \\ \mathbf{3 3}(\text { AL-518) } & 0.04 \pm 0.01 & >100 & 2500 \\ \mathbf{3 7} & >90 & \mathrm{ND} & \mathrm{ND} \\ \text { AL-470 } & 0.3 \pm 0.03 & >75.3 & 203 \\ \text { AL-471 } & 0.04 \pm 0.01 & >100 & 2500 \\ \text { AL-385 } & 0.3 \pm 0.1 & 24.9 & 83 \\ \text { pirodavir } & 0.3 \pm 0.1 & >100 & 333\end{array}$

${ }^{a}$ All average values are in micromolar $(\mu \mathrm{M})$ and are a summary of multiple dose-response curves $(>2)$ in multiple independent $(>1)$ experiments. ${ }^{b} \mathrm{EC}_{50}$ : concentration of the compound at which the virus-induced cytopathic effect (CPE) is reduced by $50 \% .{ }^{c} \mathrm{CC}_{50}$ : concentration of the compound at which a $50 \%$ reduction in cell viability is observed. ${ }^{d} \mathrm{SI}$ : selectivity index $\left(\mathrm{CC}_{50} / \mathrm{EC}_{50}\right)$. ${ }^{e} \mathrm{ND}$ : not determined.

These tests were carried out in cell culture using rhabdomyosarcoma $(\mathrm{RD})$ cells, which are known for their high susceptibility to EV71-induced cell death. ${ }^{51}$

C2/C5/C7 triply arylated Trp derivative 37 did not show any anti-EV71 activity at concentrations up to $90 \mu \mathrm{M}$. The lack of activity of this molecule could be attributed to its small size (only one indole ring) or rigidity. This finding is consistent with our previous results suggesting an important role for multivalency in the eventual antiviral activity of this type of compound. $^{26,38}$ Consequently, the presence of a central scaffold radiating three or four Trp units decorated with phenyl rings bearing carboxylic groups, particularly isophthalic acid moieties, is crucial for activity.

Moving the $\mathrm{COOH}$ aryl substituent from $\mathrm{C} 2$ to $\mathrm{C} 7$ resulted in less potent compounds, as can be seen by comparing the novel C7-arylated tripodal $16\left(\mathrm{EC}_{50}: 1.2 \mu \mathrm{M}\right)$ with $\mathrm{C} 2$-arylated prototype AL-470 $\left(\mathrm{EC}_{50}: 0.3 \mu \mathrm{M}\right)$ and the novel C7-arylated tetrapodal $23\left(\mathrm{EC}_{50}: 0.3 \mu \mathrm{M}\right)$ with $\mathrm{AL}-471\left(\mathrm{EC}_{50}: 0.04 \mu \mathrm{M}\right)$.

The derivatives possessing a tetrapodal skeleton $[21-23,32$, and 33 (AL-518)] are considerably more potent $\left(\mathrm{EC}_{50}: 0.04-\right.$ $3.1 \mu \mathrm{M})$ than their counterparts with a tripodal skeleton 1416, $31\left(\mathrm{EC}_{50}: 0.2-61.6 \mu \mathrm{M}\right)$. Tetrapodal $21\left(\mathrm{EC}_{50}: 3.1 \mu \mathrm{M}\right)$ and tripodal $14\left(\mathrm{EC}_{50}: 54.8 \mu \mathrm{M}\right)$, substituted on $\mathrm{C} 7$ with phenyl rings carrying one $\mathrm{COOH}$ at the meta position, have a potency similar to that of their counterparts $22\left(\mathrm{EC}_{50}: 1.7 \mu \mathrm{M}\right)$ and $15\left(\mathrm{EC}_{50}: 61.6 \mu \mathrm{M}\right)$, with phenyl rings carrying one $\mathrm{COOH}$ at the para position. This data seems to indicate that the position of the carboxylic acid group on the phenyl ring does not have a great impact on anti-EV71 activity. Finally, 33 (AL-518), which is doubly arylated on C2 and C7 with isophthalic acid moieties, turned out to be as potent $\left(\mathrm{EC}_{50}\right.$ : $0.04 \mu \mathrm{M})$ as C2-arylated prototype AL-471 ( $\left.\mathrm{EC}_{50}: 0.04 \mu \mathrm{M}\right)$. Taken together, the SAR data indicate that $3,5-\mathrm{COOH}$ substitution on the phenyl ring is advantageous over single 3- or 4-substitutions (cf. 23 vs 21 and 22, and 33 vs 32) and also that $\mathrm{C} 2 / \mathrm{C} 7$ arylation is superior to $\mathrm{C} 7$ arylation alone (cf. 
33 vs 23 ) but not to C2-arylation with isophthalic acid (cf. 33 vs AL-471).

Subsequently, compound 33 (AL-518), with the best activity/toxicity profile, was evaluated in cell-based assays against (i) a panel of other representative enteroviruses, (ii) a panel of clinical EV71 isolates representative of (sub)genogroups B2, B5, C2, and C4, and (iii) EV-A71 strains that harbor single (S184T and P246S) and double (S184T/ P246S) mutations in VP1 that confer resistance to the AL-385 prototype, ${ }^{26,27}$ which has been demonstrated to bind to the fivefold vertex of the viral capsid. ${ }^{52}$ The prototypes AL-470 and AL-471 were also included as reference compounds.

The summary of the results obtained is that 33 (AL-518) is (i) quite a specific inhibitor of EV71 replication because no antiviral activity was observed against the other viruses assayed (Table 2); (ii) active against all of the clinical strains (B2, B5,

Table 2. Evaluation of Compound 33 (AL-518) against a Panel of Representative Enteroviruses

\begin{tabular}{clll}
\multicolumn{1}{c}{ species } & \multicolumn{1}{c}{ virus } & host cell & \multicolumn{1}{c}{$\mathrm{EC}_{50}(\mu \mathrm{M})^{a}$} \\
enterovirus A & enterovirus A71 BrCr strain & $\mathrm{RD}$ & $0.04 \pm 0.007^{b}$ \\
enterovirus B & $\begin{array}{c}\text { coxsackievirus B3 Nancy } \\
\text { strain }\end{array}$ & $\mathrm{Vero} \mathrm{A}^{c}$ & $>50$ \\
enterovirus D & $\begin{array}{c}\text { enterovirus D68 CU70 } \\
\text { strain }\end{array}$ & HeLa Rh & $>50$ \\
rhinovirus A & $\begin{array}{c}\text { rhinovirus 2 } \\
\text { rhinovirus B }\end{array}$ & HeLa Rh & $>50$ \\
rhinovirus 14 & HeLa Rh & $>50$
\end{tabular}

${ }^{a}$ All values were obtained from multiple $(>2)$ independent $(>1)$ experiments. ${ }^{b}$ Following microscopic quality control, at least at one concentration of compound, no virus-induced cell death was observed, and the compound did not cause an adverse effect on the host cell on monolayer morphology. ${ }^{c}$ Vero cells, African green monkey kidney cells.

Table 3. Evaluation of the Broad-Spectrum Antiviral Effect of 33 (AL-518) against a Representative Panel of EV71 Clinical Isolates in RD Cells

$\begin{array}{clccc}\begin{array}{c}\text { EV71 } \\ \text { genogroup }\end{array} & \text { virus strain } & \begin{array}{c}33(\mathrm{AL}-518) \\ \mathrm{EC}_{50}(\mathrm{nM})^{a}\end{array} & \begin{array}{c}\mathrm{AL}-470 \mathrm{EC}_{50} \\ (\mathrm{nM})^{a}\end{array} & \begin{array}{c}\mathrm{AL}-471 \mathrm{EC}_{50} \\ (\mathrm{nM})^{a}\end{array} \\ \mathrm{~A} & \mathrm{BrCr} & 43 \pm 6 & 353 \pm 31 & 109 \pm 34 \\ \mathrm{~B} 2 & 11316 & 101 \pm 11 & 179 \pm 11 & 19 \pm 0.6 \\ \mathrm{~B} 5 & \mathrm{TW} / 70902 / & 10 \pm 1.5 & 81 \pm 13 & 5.9 \pm 0.7 \\ & 08 & 120 \pm 6 & 57 \pm 0.2 & 2.6 \pm 0.6 \\ \mathrm{C} 2 & \mathrm{H} 08300 & 11 \pm 0.2 & 38 \pm 3 & 1.4 \pm 0.7 \\ & 461 \# 812 & & & \\ \mathrm{C} 4 & \mathrm{TW} / 1956 / & 05 & & \end{array}$

${ }^{a}$ All values are in nanomolar (nM) and were obtained in multiple $(>2)$ independent $(>1)$ experiments. Following microscopic quality control, at least at one concentration of compound, no virus-induced cell death was observed, and the compound did not cause an adverse effect on the host cell or monolayer morphology.

C2, and C4) (Table 3), but in contrast to prototypes AL-470 and AL-471, it is less potent against B2 and C2 viruses than against the $\mathrm{BrCr}$ lab strain (sub-genogroup $\mathrm{A}$ ) - although its activity on the clinical isolates $\mathrm{B} 5$ and $\mathrm{C} 4$ was improved with respect to that found for the $\mathrm{BrCr}$ lab strain albeit in a lesser degree than that found for the prototypes AL-470 and AL471; and (iii) more resilient to the resistance-conferring mutations because the loss of sensitivity against these strains was only two- to fourfold (Table 4). Considering the structural similarity between 33 (AL-518) and AL-471, we surmise that

Table 4. Cross-Resistance Data and Resilience of 33 (AL518) to Mutations in VP1

\begin{tabular}{lccc} 
& \multicolumn{3}{c}{$\mathrm{EC}_{50}(\mu \mathrm{M})^{a}$} \\
\cline { 2 - 4 } EV-A71 & AL-385 & AL-471 & 33 (AL-518) \\
$\begin{array}{c}\text { BrCr wild } \\
\text { type }\end{array}$ & $0.3 \pm 0.01$ & $0.1 \pm 0.03$ & $0.03 \pm 0.01$ \\
$\begin{array}{l}\text { VP1 } \\
(\text { S184T) }\end{array}$ & $2.0 \pm 0.1(7.1)$ & $0.9 \pm 0.05(8.5)$ & $0.1 \pm 0.01(4.3)$ \\
VP1 & $4.7 \pm 0.2(16.8)$ & $1.9 \pm 0.04(5.6)$ & $0.03 \pm 0.01(1.0)$ \\
$(\mathrm{P} 246 \mathrm{~S})$ & & & \\
VP1 \\
$(\mathrm{S} 184 \mathrm{~T} /$ & $8.9 \pm 0.5(31.9)$ & $2.2 \pm 0.08(6.2)$ & $0.06 \pm 0.04(2.0)$ \\
$\quad \mathrm{P} 246 \mathrm{~S})$ & & &
\end{tabular}

${ }^{a}$ Averages and standard deviations (SDs) were calculated from data obtained from three independent antiviral assays. Italicized numbers in parentheses indicate fold resistance.

33 (AL-518) also binds to VP1 residues around the fivefold axis but its binding affinity (or avidity) does not diminish significantly in the presence of these amino acid replacements. Our molecular modeling results (see below) offer a plausible explanation to these findings.

Activity against HIV. The newly synthesized compounds were also evaluated for their in vitro inhibitory activity against HIV-1 and HIV-2 replication in cultured $\mathrm{CD}^{+} \mathrm{T}$ cells (Table 5). The previously described C2-arylated tripodal (I, II) and tetrapodal (III, IV) derivatives (Figure 3), as well as prototypes AL-470 and AL-471 (Figure 1), were assayed under the same conditions for comparative purposes. The reference compounds dextran sulfate-5000 (DS-5000), a negatively charged HIV adsorption inhibitor, ${ }^{53}$ and pradimicin

Table 5. Anti-HIV-1 and HIV-2 Activities of the Synthesized Compounds against HIV-1 and HIV-2 in MT-4 Cells

$\begin{array}{lllll}\text { compound } & \begin{array}{c}\mathrm{HIV}-1(\mathrm{NL} 4.3) \\ \mathrm{EC}_{50}(\mu \mathrm{M})^{a}\end{array} & \begin{array}{c}\mathrm{HIV}-2(\mathrm{ROD}) \\ \mathrm{EC}_{50}(\mu \mathrm{M})^{a}\end{array} & \begin{array}{c}\mathrm{CC}_{50} \\ (\mu \mathrm{M})^{b}\end{array} & \mathrm{SI}^{c} \\ \mathbf{1 4} & 45.1 \pm 10.2 & >30 & >100 & 24.4 \\ \mathbf{1 5} & 12.0 \pm 10.2 & 49.7 \pm 8.6 & >100 & 8.3 \\ \mathbf{1 6} & 0.4 \pm 0.2 & 1.9 \pm 0.4 & >100 & 232.6 \\ \mathbf{2 1} & 14.1 \pm 0.6 & 7.9 \pm 0.9 & >100 & 7.1 \\ \mathbf{2 2} & 6.5 \pm 2.5 & 0.4 \pm 0.3 & >100 & 15.5 \\ \mathbf{2 3} & 0.02 \pm 0.01 & 0.02 \pm 0.02 & 75.00 & 4687.5 \\ 31 & 0.04 \pm 0.01 & 0.07 \pm 0.01 & >100 & 2564.1 \\ 32 & 0.2 \pm 0.2 & 0.02 \pm 0.02 & >100 & 476.2 \\ 33(\mathrm{AL}- & 0.006 \pm 0.005 & 0.06 \pm 0.02 & >100 & 16129 \\ \quad 518) & & & & \\ 37 & >100 & >100 & >100 & \\ \text { I } & 16.0 \pm 5.7 & 64 \pm 28 & >100 & 6 \\ \text { II } & 2.4 \pm 1.3 & >71 & 71 & 29.6 \\ \text { III } & 2.0 \pm 0.6 & 0.8 \pm 0.5 & >100 & 50 \\ \text { IV } & 0.7 \pm 0.5 & 0.7 \pm 0.8 & >100 & 137 \\ \text { AL-470 } & 0.3 \pm 0.1 & 0.6 \pm 0.8 & >100 & 370 \\ \text { AL-471 } & 0.07 \pm 0.04 & 0.02 \pm 0.09 & >100 & 1429 \\ \text { DS-5000 } & 0.07 \pm 0.02 & 0.03 \pm 0.01 & >20 & 285.7 \\ \text { PRM-A } & 3.3 \pm 1.2 & 5.9 \pm 3.7 & >100 & 30.3\end{array}$

${ }^{a} \mathrm{EC}_{50}$ : concentration of the compound at which the virus-induced cytopathic effect is reduced by $50 \%$. ${ }^{b} \mathrm{CC}_{50}$ : concentration of the compound at which a $50 \%$ reduction in cell viability is observed. ${ }^{c} \mathrm{SI}$ : selectivity index $\left(\mathrm{CC}_{50} / \mathrm{EC}_{50}\right)$. 


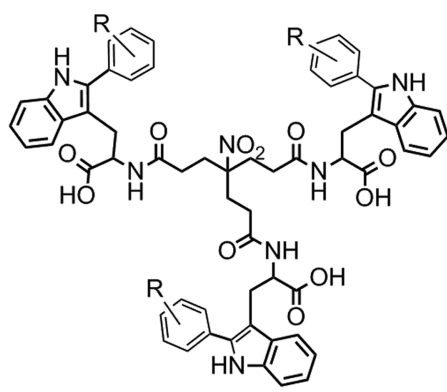

I, R: 3-COOH

II, R: $4-\mathrm{COOH}$

AL-470, R: 3,5-COOH

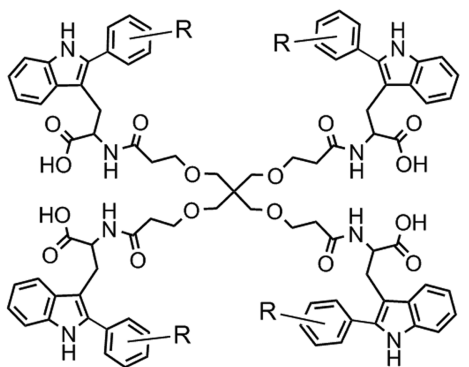

III, R: 3-COOH

IV, R: $4-\mathrm{COOH}$

AL-471, R: 3,5-COOH

Figure 3. Structure of the previously reported C2-arylated Trp derivatives I-IV and prototypes AL-470 and AL-471.

$$
\begin{aligned}
& -12.5 \mu \mathrm{M} \\
& -\quad 6.25 \mu \mathrm{M} \\
& -\quad 3.13 \mu \mathrm{M} \\
& -1.56 \mu \mathrm{M} \\
& -\quad 0.78 \mu \mathrm{M} \\
& -\quad 0.39 \mu \mathrm{M} \\
& -\quad 0.19 \mu \mathrm{M} \\
& -\quad 0.1 \mu \mathrm{M} \\
& -1: 1 \mathrm{Langm} \\
& \\
& \\
& -0 \mathrm{nM} \\
& -10 \mathrm{nM} \\
& -\quad 39 \mathrm{nM} \\
& -159 \mathrm{nM} \\
& -\quad 625 \mathrm{nM} \\
& -\quad 2500 \mathrm{nM} \\
& -10000 \mathrm{nM}
\end{aligned}
$$

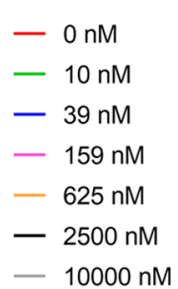$$
\text { - 1:1 Langmuir fitting }
$$
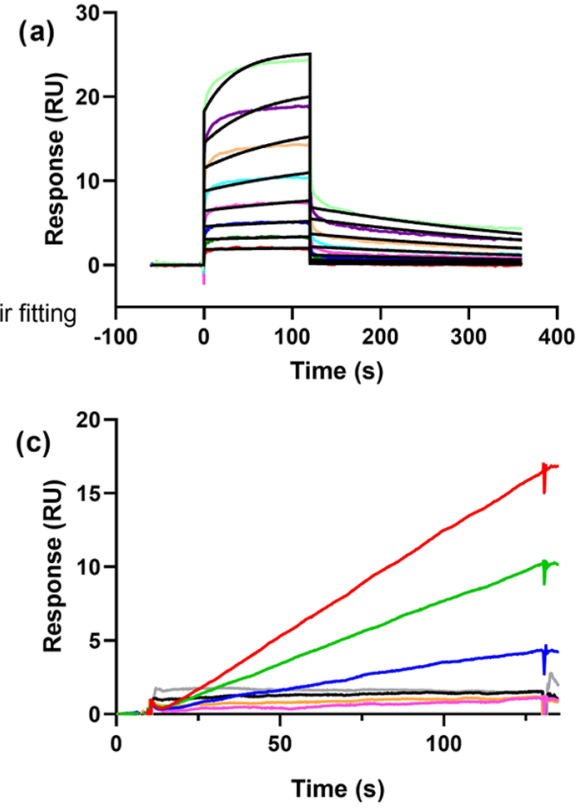
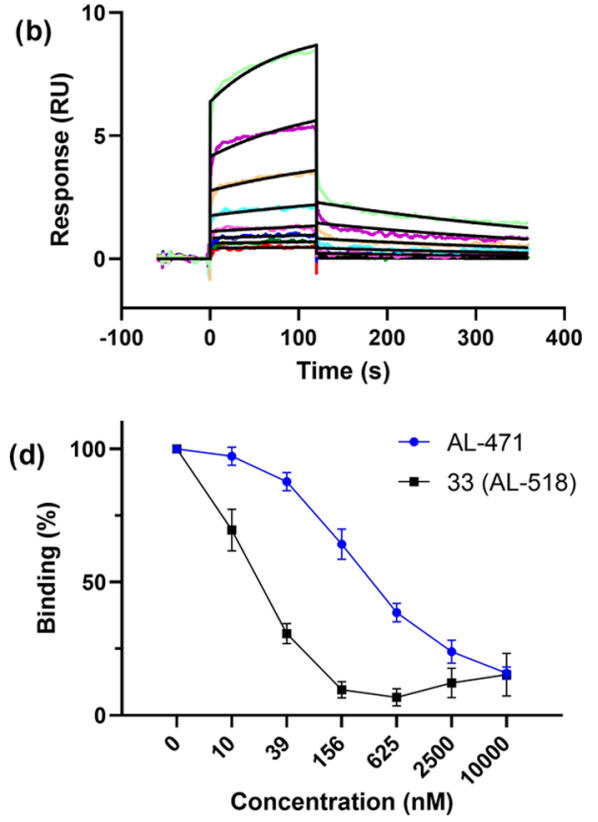

Figure 4. Multiple cycle kinetics of (a) 33 (AL-518) and (b) AL-471 binding to HIV gp120 (results from one of four replicate experiments). Note the different scale of the $Y$-axes in left and right panels. The colored curves represent the real-time binding responses, whereas the black curves were obtained by fitting to a 1:1 Langmuir model. The concentrations ranged from 0.1 to $12.5 \mu \mathrm{M}$, and both analytes were diluted using twofold dilution steps. For both analytes, the ability to bind to gp 120 was confirmed. (c) SPR sensorgram of 33 (AL-518) at varying concentrations mixed with 25 $\mathrm{nM}$ gp120 binding to immobilized CD4. Serial concentrations ranged from 10000 to $10 \mathrm{nM}$ using fourfold dilution steps. Results are shown from one of three replicate experiments. (d) Dose-dependent inhibition by AL-471 and 33 (AL-518) of the binding of gp120 to CD4, calculated by the responses of three replicate SPR experiments.

A (PRM-A), a gp120 carbohydrate-binding entry inhibitor, ${ }^{54}$ showed antiviral activities within previously reported ranges. $^{53,54}$

The C2/C5/C7 triply arylated Trp derivative 37 did not show any anti-HIV activity at concentrations up to $100 \mu \mathrm{M}$ (Table 5). This finding demonstrates, as reported above for EV71, the importance of multivalency for activity. For the multivalent derivatives, moving the $\mathrm{COOH}$ aryl substituent from $\mathrm{C} 2$ to $\mathrm{C} 7$ resulted in decreased anti-HIV potency, as can be seen by pairwise comparison of the range of activities displayed by the novel C7-arylated tripodal 14-16 (EC ${ }_{50}$ : $45.1-0.4 \mu \mathrm{M})$ and tetrapodal 21 and $22\left(\mathrm{EC}_{50}: 14.1-6.5 \mu \mathrm{M}\right)$ derivatives versus those of the C2-arylated tripodal I, II, and AL-470 $\left(\mathrm{EC}_{50}: 16.0-0.3 \mu \mathrm{M}\right)$ and tetrapodal III and IV $\left(\mathrm{EC}_{50}: 2.0-0.7 \mu \mathrm{M}\right)$ derivatives (Table 5). An exception was the C7-arylated tetrapodal compound $23\left(\mathrm{EC}_{50}: 0.02 \mu \mathrm{M}\right)$, which turned out to be 3.5 -fold more potent than the respective $\mathrm{C} 2$ counterpart $\mathrm{AL}-471\left(\mathrm{EC}_{50}: 0.07 \mu \mathrm{M}\right)$.

In contrast to what was observed for EV71, the compounds with the $\mathrm{COOH}$ aryl substituent at the para position were more potent than those with the $\mathrm{COOH}$ aryl substituent at meta, as can be seen by comparing tripodal $14\left(\mathrm{EC}_{50}: 45.1\right.$ $\mu \mathrm{M})$ and $15\left(\mathrm{EC}_{50}: 12.0 \mu \mathrm{M}\right)$, on the one hand, and tetrapodal $21\left(\mathrm{EC}_{50}: 14.1 \mu \mathrm{M}\right)$ and $22\left(\mathrm{EC}_{50}: 6.5 \mu \mathrm{M}\right)$, on the other.

Interestingly, tripodal $16\left(\mathrm{EC}_{50}: 0.4 \mu \mathrm{M}\right)$ and tetrapodal 23 $\left(\mathrm{EC}_{50}: 0.02 \mu \mathrm{M}\right)$ derivatives, both arylated at $\mathrm{C} 7$ of the indole ring with isophthalic acid, were the most potent of the $\mathrm{C} 7$ series. This result corroborates the previous finding that this moiety is so far the optimal aryl substituent for attachment to the Trp indole ring. ${ }^{38}$ 
Potency enhancement upon double arylation at C2 and C7 was observed in all members of the tripodal and tetrapodal series, as can be seen by comparing the activities shown by the doubly arylated $31\left(\mathrm{EC}_{50}: 0.04 \mu \mathrm{M}\right)$ with those of the C7arylated $16\left(\mathrm{EC}_{50}: 0.4 \mu \mathrm{M}\right)$ and $\mathrm{C} 2$-arylated $\mathrm{AL}-470\left(\mathrm{EC}_{50}\right.$ : $0.3 \mu \mathrm{M})$ and also those of the doubly arylated $32\left(\mathrm{EC}_{50}: 0.2\right.$ $\mu \mathrm{M})$ with those of the C7-arylated $22\left(\mathrm{EC}_{50}: 6.5 \mu \mathrm{M}\right)$ and $\mathrm{C} 2$ arylated IV $\left(\mathrm{EC}_{50}: 0.7 \mu \mathrm{M}\right)$. Finally, double arylation at $\mathrm{C} 2$ and C7 with isophthalic acid moieties led to 33 (AL-518) $\left(\mathrm{EC}_{50}\right.$ : $0.006 \mu \mathrm{M}$ ), which demonstrated significantly improved antiHIV activity over both the C2-arylated prototype AL-471 $\left(\mathrm{EC}_{50}: 0.07 \mu \mathrm{M}\right)$ and the C7-arylated $23\left(\mathrm{EC}_{50}: 0.02 \mu \mathrm{M}\right)$. Interestingly, the anti-HIV-1 activity displayed by 33 (AL-518) was found to be far below its toxicity threshold $\left(\mathrm{CC}_{50}>100\right.$ $\mu \mathrm{M})$, and for this reason, the selectivity index $\left(\mathrm{CC}_{50} / \mathrm{EC}_{50}\right.$ ratio, $\mathrm{SI}=16129)$ was greatly improved with respect to $\mathrm{AL}$ 471 (SI = 1429). Moreover, 33 (AL-518) also demonstrated potent in vitro antiviral activity against HIV-2 $\left(\mathrm{EC}_{50} \approx 0.06\right.$ $\mu \mathrm{M})$.

Taken together, these data indicate that, of all of the Trp derivatives synthesized to date, the most potent against HIV $\left(\mathrm{EC}_{50}: 6 \mathrm{nM}\right)$ is 33 (AL-518), which can thus be considered a novel and promising lead compound.

Mode of Action in the Context of HIV Infection. Surface Plasmon Resonance Analysis. As mentioned above, the prototype compounds AL-470 and AL-471 inhibit an early step in the replicative cycle of HIV by interacting with gp 120 of the HIV envelope. ${ }^{26,38}$ To investigate whether this glycoprotein is also the potential target of the novel compounds, recombinant HIV-1 IIIB gp120 (produced in Chinese hamster ovary cells) was bound to a sensor chip as a monomer and its interaction with 33 (AL-518) was measured using SPR. The prototype AL-471 was used as a positive control. The results confirm that compound 33 (AL-518), similarly to AL-471, binds to gp120 and the interaction is concentration-dependent.

Next, detailed SPR-directed affinity was determined using concentrations of 33 (AL-518) ranging from 12.5 to $0.1 \mu \mathrm{M}$ (Figure 4a,b and Table 6). Tetrapodal 33 (AL-518) showed a

Table 6. Apparent $K_{\mathrm{D}}$ for the Interaction between HIV-1 gp120 and $33(\mathrm{AL}-518)^{a}$

$\begin{array}{lccc}\text { compound } & k_{\mathrm{a}}\left(\times 10^{3} \mathrm{M}^{-1} \mathrm{~s}^{-1}\right) & k_{\mathrm{d}}\left(\times 10^{-3} \mathrm{~s}^{-1}\right) & K_{\mathrm{D}}(\mu \mathrm{M}) \\ 33 \text { (AL-518) } & 3.34 \pm 1.02 & 2.45 \pm 0.34 & 0.84 \pm 0.34 \\ \text { AL-471 } & 1.20 \pm 0.55 & 6.97 \pm 4.59 & 5.31 \pm 1.89\end{array}$

${ }^{a}$ Average and standard deviation of kinetic parameters obtained from four replicate SPR experiments measuring the binding response between gp120 and 33 (AL-518)/AL-471.

higher association rate constant $\left(k_{\mathrm{a}}\right)$ than did AL-471, which means that the former binds faster to gp120, and also a lower dissociation rate constant $\left(k_{\mathrm{d}}\right)$, which entails a slower detachment from gp120. These kinetic results indicate that the interaction of gp120 with $33(\mathrm{AL}-518)\left(K_{\mathrm{D}}=0.84 \mu \mathrm{M}\right)$ is around sixfold stronger than with AL-471 $\left(K_{\mathrm{D}}=5.31 \mu \mathrm{M}\right)$.

Overall, the higher affinity (i.e., smaller $K_{\mathrm{D}}$ ) for gp120 of 33 (AL-518) than that of the prototype AL-471 nicely correlates with the superior anti-HIV-1 activity that was observed for the former compound in the cell-based antiviral assay.

Direct inhibition of viral gp120 binding to the human cell receptor CD4 by 33 (AL-518) and AL-471 was demonstrated by SPR. A dose-dependent decrease of binding was observed when $25 \mathrm{nM}$ gp120 was mixed with varying concentrations of 33 (AL-518) (Figure 4c). These results, together with those of AL-471 were plotted on a graph to investigate the differences in potency between the two compounds (Figure 4d). 33 (AL518) showed a stronger inhibition profile compared to AL471. Indeed, 33 (AL-518) inhibited $50 \%$ of gp120-CD4 binding in the $10-40 \mathrm{nM}$ range, whereas $156-625 \mathrm{nM}$ was needed to obtain the same degree of inhibition with AL-471. This means that 33 (AL-518) is at least 16 times more potent than AL-471.

Activity against CXCR4- and CCR5-Tropic HIV-1 Strains. We next investigated whether the action of 33 (AL-518) is dependent on the coreceptor used by HIV-1 for entry. To this end, the compound was tested against CXCR4- (HIV-1/ NL4.3) and CCR5-tropic (HIV-1/Ba-L) HIV-1 strains in peripheral blood mononuclear cells (PBMCs). The reference compounds maraviroc, an HIV-1 entry inhibitor that works as a negative allosteric modulator of the chemokine receptor type 5 (CCR5), ${ }^{12}$ and bicyclam AMD3100 (aka plerixafor), which blocks HIV-1 entry and membrane fusion by acting as a partial agonist of the C-X-C $\alpha$-chemokine receptor type 4 (CXCR4), ${ }^{55}$ showed antiviral activities within previously reported ranges. $^{12,55}$

As shown in Table 7, 33 (AL-518) inhibited the replication of both CXCR4- and CCR5-tropic HIV-1 strains with similar

Table 7. Activities of AL-471 and 33 (AL-518) against CXCR4- and CCR5-Tropic HIV-1 Strains ${ }^{a}$

$\begin{array}{lccc}\text { compound } & \begin{array}{c}\text { concentration } \\ \text { units }\end{array} & \begin{array}{c}\mathrm{HIV}-1(\underset{b}{\mathrm{NL}} 4.3) \\ \mathrm{EC}_{50}\end{array} & \begin{array}{c}\mathrm{HIV}-1(\mathrm{Ba}-\mathrm{L}) \\ \mathrm{EC}_{50}\end{array} \\ \text { AL-471 } & \mathrm{nM} & 76 & 280 \\ 33 \text { (AL-518) } & \mathrm{nM} & 33 & 36 \\ \text { maraviroc } & \mathrm{nM} & >1000 & 4.48 \\ \text { AMD3100 } & \mathrm{ng} / \mathrm{mL} & 3.57 & >1000\end{array}$

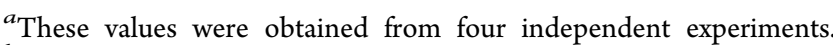
${ }^{b} \mathrm{EC}_{50}: 50 \%$ inhibitory concentration or compound concentration required to inhibit the $\mathrm{HIV}$-induced cytopathogenic effect in PBMC cells.

potencies $\left(\mathrm{EC}_{50}: 33\right.$ and $36 \mathrm{nM}$, respectively). In contrast, the CXCR4-tropic HIV-1 strain (NL4.3) was insensitive to the action of maraviroc, as expected, while the CCR5-tropic HIV-1 strain (HIV-1/Ba-L) was unaffected by AMD3100 at concentrations up to $1000 \mathrm{ng} / \mathrm{mL}$. Thus, it seems that the action of 33 (AL-518) is independent of the coreceptor used by HIV-1 for entry. The prototype AL-471 also inhibits both CXCR4- and CCR5-tropic HIV-1 strains, although it seems to be tenfold more potent against the CXCR4-tropic HIV-1 strain (NL4.3).

As mentioned in the Introduction section, positively charged residues are frequently found at critical positions in the V3 loop of CXCR4-tropic viruses, ${ }^{20}$ while neutral or negatively charged residues are found at these positions in CCR5-tropic viruses. ${ }^{21}$ The finding that 33 (AL-518) inhibits the productive infection of cells by both CXCR4- and CCR5-tropic HIV-1 strains is strongly suggestive of its binding to certain highly conserved structural features, e.g., $\mathrm{N}$-glycans, even though the involvement of specific gp120 amino acids cannot be excluded.

Competition-Binding Experiments with Monoclonal Antibodies Directed to Specific Regions of the HIV-1 gp120 Envelope. We then investigated the putative gp120 binding site for this class of compounds using competition-binding 
experiments with $\mathrm{mAbs}$ directed to different protein regions: (i) human mAb clone $2 \mathrm{G} 12$, whose epitope, composed entirely of N-linked glycans, is centered at position N332; ${ }^{56}$ (ii) human $\mathrm{mAb}$ clone $447-52 \mathrm{D}$, which recognizes the tip of the V3 loop; ${ }^{57,58}$ and (iii) the mouse clones 9284 and 9305, which interact with the base of the V3 loop (amino-terminal side). ${ }^{59}$

These tests were carried out in cell culture using $\mathrm{CD}^{+} \mathrm{MT}$ $4 \mathrm{~T}$ cells that express high levels of gp120 on their membrane when they become infected. Compound 33 (AL-518) was added and the staining results in the presence of the abovementioned antibodies were analyzed by flow cytometry. The prototype AL-471 and the mannose-specific lectin Hippeastrum hybrid agglutinin (HHA $)^{60}$ were also assayed under the same conditions for comparative purposes. The results of these evaluations are summarized in Table 8 , as well

Table 8. Inhibition Profile of AL-471 and 33 (AL-518) on HIV-1-Envelope Directed Anti-gp120 mAbs ${ }^{a}$

$\begin{array}{lccccc}\text { compound } & \begin{array}{c}\text { concentration } \\ \text { units }\end{array} & \begin{array}{c}2 \mathrm{G} 12 \\ \mathrm{IC}_{50}\end{array} & \begin{array}{c}447-52 \mathrm{D} \\ \mathrm{IC}_{50}\end{array} & \begin{array}{c}9284 \\ \mathrm{IC}_{50}\end{array} & \begin{array}{l}9305 \\ \mathrm{IC}_{50}\end{array} \\ \begin{array}{l}\text { AL-471 } \\ \text { 33 (AL- }\end{array} & \mu \mathrm{M} & >100 & >100 & >100 & >100 \\ \text { 518) } & & >100 & 6.8 & 3.8 & >100 \\ \text { HHA } & \mu \mathrm{M} / \mathrm{mL} & 2.0 & \mathrm{ND} & 2.1 & >20\end{array}$

${ }^{a}$ MT-4 cells were infected with HIV-1 NL4.3 and 4 days after infection stained with or without the addition of the compounds in the presence of the selected set of specific anti-gp120 mAbs. Percentage inhibition was calculated on the mean fluorescence intensity by flow cytometry. as in Tables S1 and S2 (Supporting Information). It can be seen that the interaction of all of these mAbs with gp120 was unaffected by AL-471 at concentrations up to $100 \mu \mathrm{M}$. In contrast, 33 (AL-518) caused dose-dependent inhibition of the binding of mAbs 447-52D and 9284 (average $\mathrm{IC}_{50}$ values of 6.8 and $3.8 \mu \mathrm{M}$, respectively). These results strongly suggest that 33 (AL-518) can interact with the same epitopes that are recognized by these $\mathrm{mAbs}$, which implies some degree of overlap of their binding regions. The core epitope of $\mathrm{mAb} 447$ $52 \mathrm{D}$ is the highly conserved motif Gly-Pro-Gly-Arg/Gln (GPGR/Q, residues $312-315$ ) at the tip of the V3 loop, ${ }^{58,61}$ while antibody 9284 interacts with the base of this same loop. ${ }^{59}$ Interestingly, 33 (AL-518) did not prevent the binding of the mAb 2G12, whose binding-as well as that of $\mathrm{mAb}$ 9284-was significantly affected by HHA.

Putative Binding Modes Using Computational Analysis. For attachment of 33 (AL-518) to EV-A71, we propose a binding mode similar to that reported for AL-385, ${ }^{38}$ consisting of the location of a single molecular entity at each capsid vertex where at least one of the decorated Trp moieties can establish multiple specific interactions with selected residues, while the rest of the molecule engages in additional contacts with neighboring amino acids (Figure 5). Thus, interaction of the virus with its cellular receptors PSGL-1 and heparan sulfate on the host cell membrane is prevented and EV-A71 entry is blocked.

In the case of HIV-1, we must bear in mind that the gp120 and gp41 subunits that make up the Env protein of the different HIV-1 subtypes or clades exist as populations of glycosylated variants (glycoforms) that are characterized by heterogeneous patches of oligomannose-type glycans at each

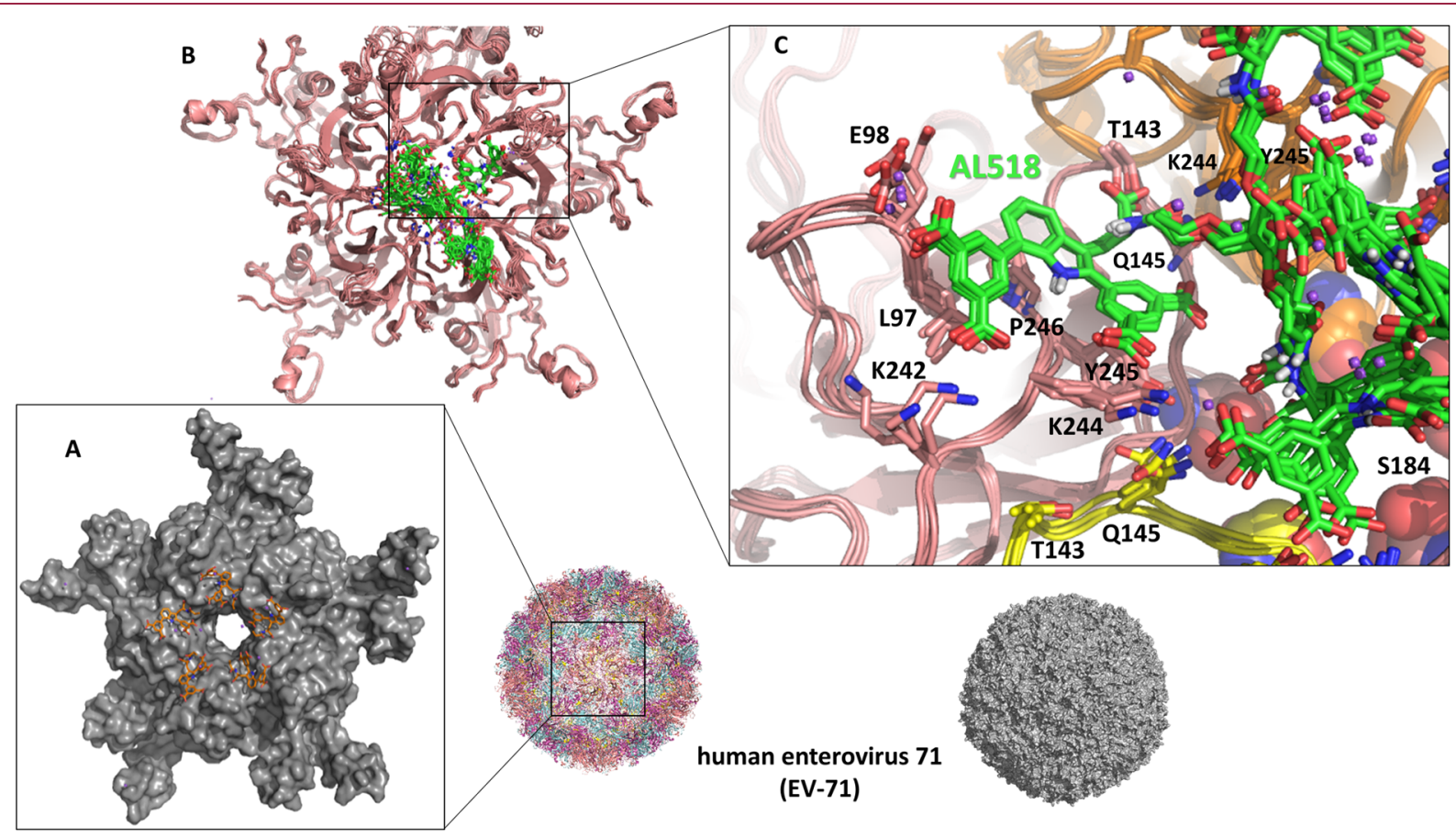

Figure 5. Molecular models of EV71. (A) Proposed binding mode of the decorated Trp moiety of 33 (AL-518) (stick representation, C atoms in orange) at the interface between subunits of the experimentally determined structure (PDB entry $6 \mathrm{UH} 7^{38}$ ) of the VP1 pentamer (gray envelope). (B) Cartoon representation of VP1 (pink) in complex with 33 (AL-518) (sticks, with C atoms in green), as found along the molecular dynamics simulations. The ten superimposed structures represent a conformational ensemble made up of snapshots extracted from the molecular dynamics trajectory every $5 \mathrm{~ns}$ and then cooled down to $273 \mathrm{~K}$ and energy-minimized. (C) Detail of the proposed binding mode for 33 (AL-518) showing the extended aromatic surface and the functional groups responsible for specific interactions with protein residues, the most important of which have been labeled. The small spheres in violet represent sodium ions. Note the spatial positions of Ser184 and Pro246. 
glycosylation site whose composition is dependent on trimerization and trimming by mannosidases. ${ }^{62}$ Since we postulated that the decorated Trp residues in our series of derivatives provide not only a flat surface for $\mathrm{CH} \cdots \pi$ interactions ${ }^{63}$ with the pyranose rings of the numerous asparagine-linked oligomannose glycans but also multiple hydrogen bonding possibilities and ionic interactions via their free carboxylic acid groups, we tested this hypothesis by first modeling and simulating the dynamic behavior of 33 (AL-518) in the presence of the high-mannose glycan $\mathrm{Man}_{9} \mathrm{GlcNAc}_{2}$-OMe. Thereafter, we modeled and simulated a membrane-embedded and heavily glycosylated HIV-1 Env trimer (Figure 6) to assess the extent of protein surface

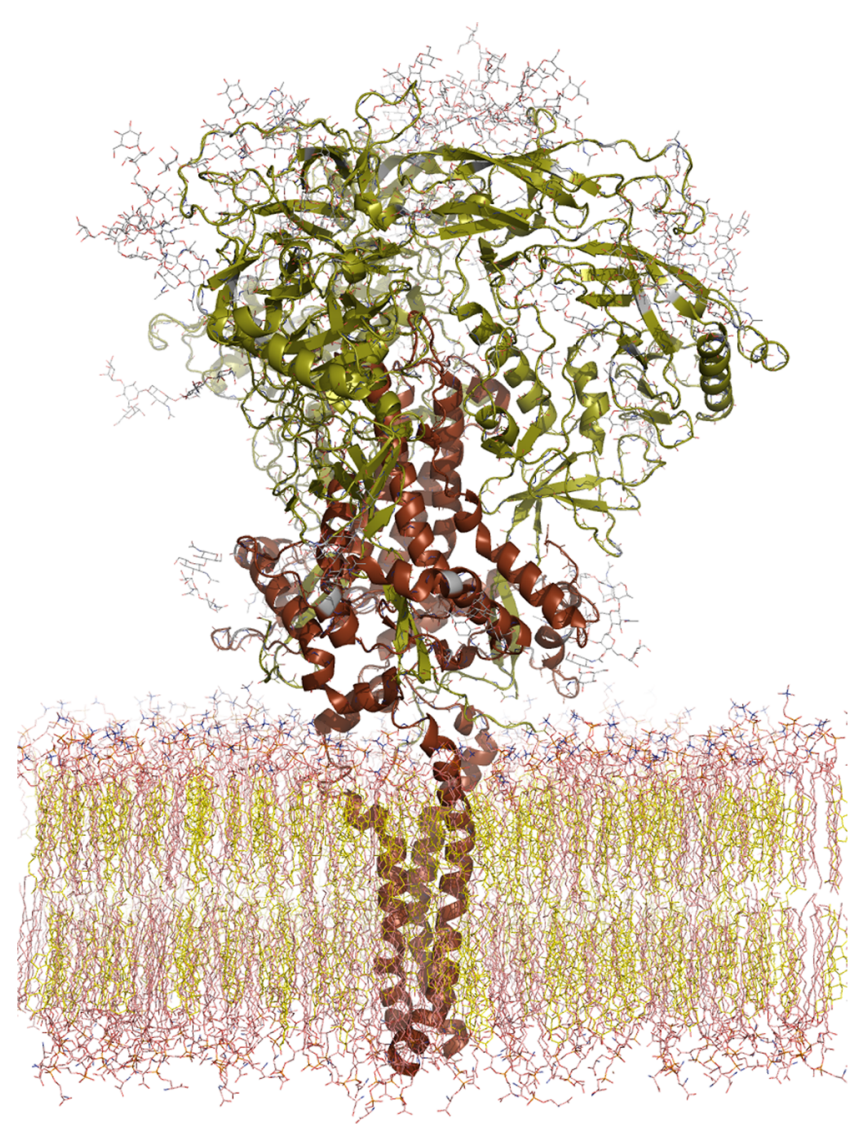

Figure 6. Molecular model of HIV-1 Env (cartoon representation), a trimer of gp120 (green) and gp41 (brown) dimers, embedded in a cholesterol-rich lipid bilayer (phospholipid and cholesterol $\mathrm{C}$ atoms colored in pink and yellow, respectively). Water molecules and counterions on both sides of the membrane have been omitted for clarity. The oligosaccharide residues GlcNAc, $\operatorname{Man}_{1} \mathrm{GlcNAc}_{2}$, $\mathrm{Man}_{3} \mathrm{GlcNAc}_{2}$, and $\mathrm{Man}_{9} \mathrm{GlcNAc}_{2}$ attached to several asparagine side chains in both gp120 and gp41 are displayed as sticks, with C atoms in gray. These sugars represent only a fraction of the $\mathrm{N}$-linked "high-mannose patches" that shield the HIV-1 envelope from immune surveillance ${ }^{64}$ but at the same time provide specific recognition by lectins, bNAbs, and, possibly, tetrapodal Trp derivatives such as $\mathbf{3 3}$ (AL-518).

coverage as well as the extracellular region in the presence of three separate 33 (AL-518) molecules initially placed at the CD4-binding site in three different orientations. By using this procedure, our sampling of ligand-receptor interactions was effectively run in triplicate and the feasibility of intermonomer bridging by the four flexible arms radiating from the central scaffold could be assessed.

Our molecular dynamics simulation results show (i) the occurrence of multiple patterns of simultaneous $\mathrm{CH} \cdots \pi$ stacking and hydrogen-bonding interactions between the carbohydrate units-mostly the central mannose in the $\alpha$ Man- $(1 \rightarrow 3)$-[ $\alpha$-Man- $(1 \rightarrow 6)]$-Man trisaccharide-and the isophthalic acid-decorated Trp residues. These interactions are enhanced and strengthened when the isophthalic acid moiety is attached not only to $\mathrm{C} 2$ but also to the $\mathrm{C} 7$ position (Figure 7 and Movie S1); (ii) the broad protein surface coverage provided by the highly mobile gp 120 and gp41 glycan "cloud" (Movie S2), which is likely to be encountered by the approaching ligands; and (iii) the targeting of gp120 by the Trp-decorated branches radiating from the 33 (AL-518) core using various angles of approach and alternative accommodations within the glycans surrounding the $\mathrm{V} 3$ loop (Figure 8 and Movie S3). It is worth noting that C2/C7 arylation on the Trp leads not only to an extended flat surface for stacking interactions relative to a singly C2- or C7-decorated Trp but also to a greater profusion and higher local density of carboxylic acid moieties that can engage in ionic bridges and hydrogen bonds with numerous sugar hydroxyls and protein side chains.

After 400 ns of complex equilibration, each 33 (AL-518) molecule appeared preferentially bound to a location close to the V3 loop of gp120, where it establishes highly exchangeable interactions with the oligomannose glycans attached to Asn residues 134,197 , and 363 , as well as with the side-chain guanidinium moieties of Arg151 and Arg469. Interestingly, this putative binding mode would preclude engagement of CD4 by gp120 and its embrace by the glycans attached to Asn residues 197 and 276 (Movie S4). Thus, this mechanism would operate similarly to, but distinctly from, that used by CD4 mimetics that directly bind to the so-called "Phe 43 cavity" at the interface between the inner and outer gp120 domains (Figure S1). In fact, it can be thought that 33 (AL-518) actually mimics bnAbs because the tetrapodal scaffold (i) facilitates both broad glycan recognition and ready access to parts of the protein surface of gp120 and (ii) tolerates microheterogeneity at glycosylation sites.

\section{CONCLUSIONS}

The present work built on results from a recently described novel class of tripodal and tetrapodal Trp-containing compounds that bear one or two carboxylic acid groups on a phenyl ring directly attached to the $\mathrm{C} 2$ position of every indole ring and potently block cell entry not only of HIV but also of the unrelated EV71 virus. The new strategy consisted of transferring the carboxylic acid containing aryl moiety from $\mathrm{C} 2$ to C7. To selectively synthesize the C7-arylated compounds, we took advantage of the Movassaghi and Maleczka methods that allow 2,7-diborylation of Trp followed by in situ bismuth acetate-catalyzed C2 protodeboronation. The next step relied on the Suzuki-Miyaura cross-coupling reaction to form the $\mathrm{C}-\mathrm{C}$ bond between the indole core and the carboxylic acid aryl moiety, followed by coupling of the arylated Trp to the corresponding tripodal or tetrapodal central scaffold.

The most potent compound, 33 (AL-518) (EC ( $_{50}$ HIV: 6 $\mathrm{nM}$; $\mathrm{EC}_{50} \mathrm{EV71}: 40 \mathrm{nM}$ ), is a tetrapodal Trp derivative that is doubly arylated with isophthalic acid moieties at positions C2 and $\mathrm{C} 7$ of each indole ring. SPR studies revealed that 33 (AL518) binds to HIV-1 gp120 with greater affinity than prototype 
A

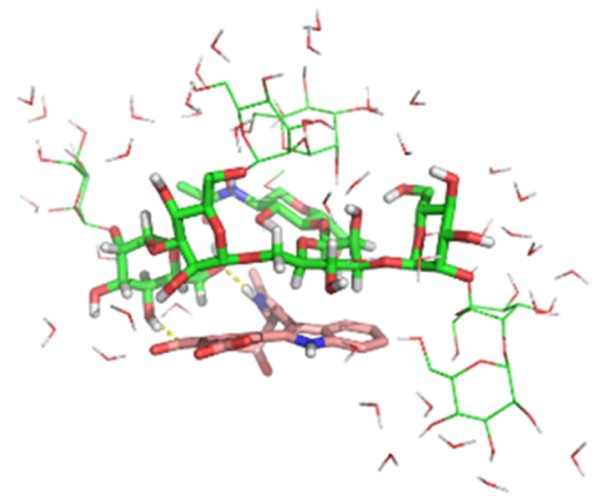

B

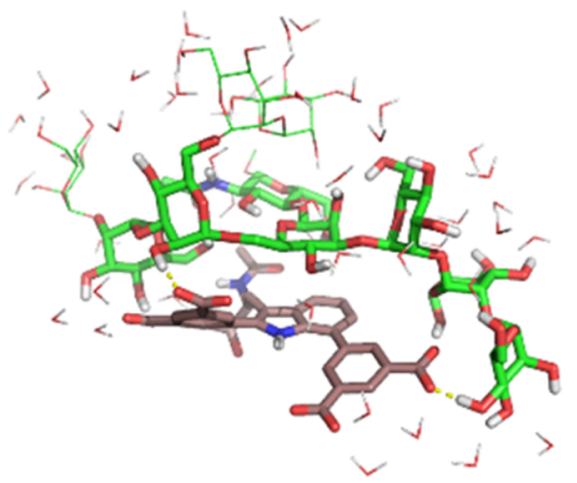

Figure 7. Simultaneous stacking of the central mannose in Man ${ }_{9}$ GlcNAc on either a C2 singly arylated (A) or a C2/C7 doubly arylated (B) Ncapped Trp residue and distinct hydrogen-bonding interactions with surrounding hydroxyl groups.

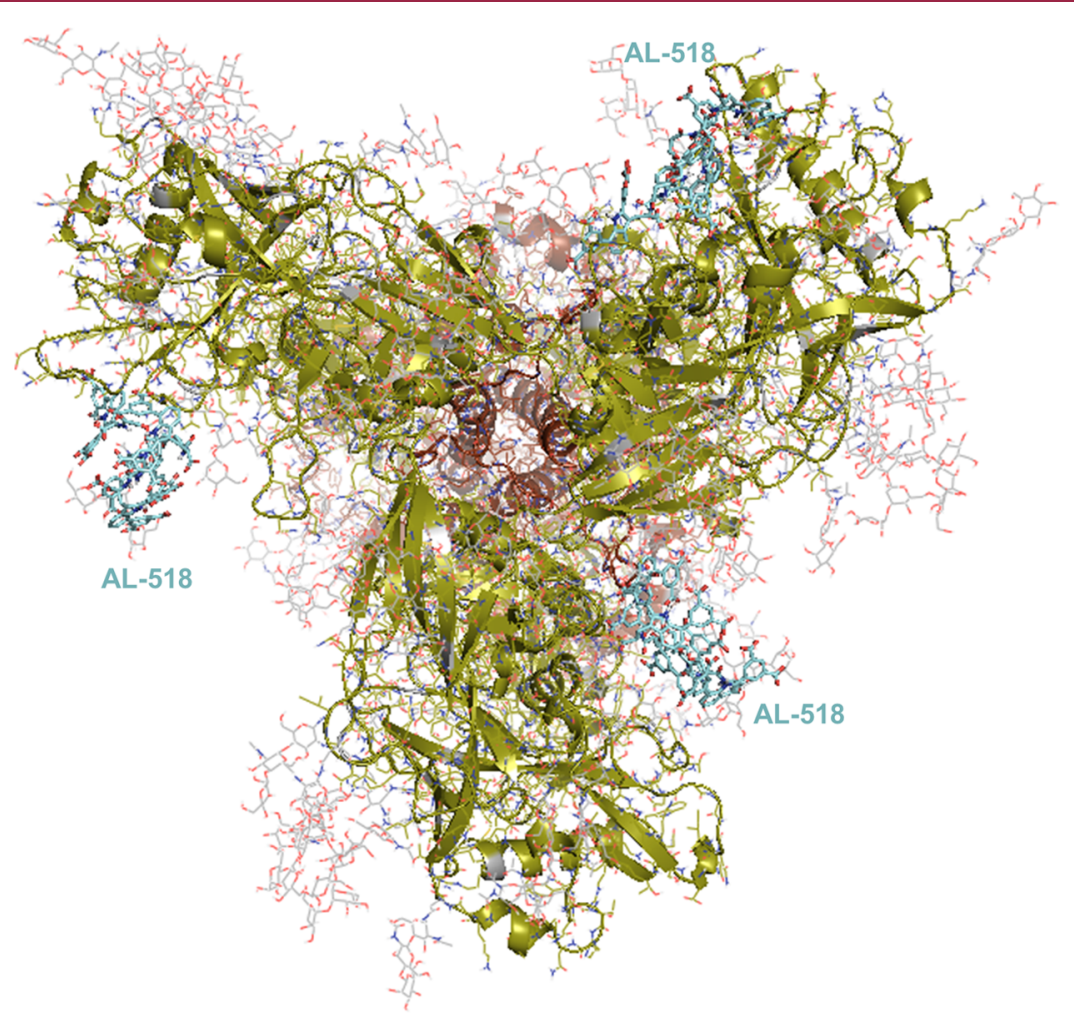

Figure 8. Observed binding modes for three 33 (AL-518) molecules (sticks, C atoms in cyan) after 400 ns of unrestrained molecular dynamics simulations of the complex. Note that this top view corresponds to a $90^{\circ}$ rotation about the $X$-axis with respect to the lateral view shown in Figure 6.

AL-471, in good accord with its superior anti-HIV-1 activity in the cellular assay. We show that $\mathbf{3 3}$ (AL-518) inhibits both X4and R5-tropic viral strains with comparable efficacies. This implicates that the target of interaction on gp120 must be rather conserved (i.e., N-glycans, but not excluding other interaction points with gp120 as well). Competition experiments with antibodies directed to specific regions of the gp120 V3 loop suggest that 33 (AL-518) interacts with the same epitopes as mAbs 447-52D and 9284 (the tip and aminoterminal side of the gp120 V3 loop). Molecular modeling showed that 33 (AL-518) could interact with these regions through multiple hydrogen bonds and $\mathrm{CH} \cdots \pi$ interactions and may be through electrostatic interactions with arginine residues. Moreover, 33 (AL-518), like the prototype, AL471, could interact with the conserved cluster of oligomannose glycans or the "high-mannose patch" that shields the HIV envelope.

The surfaces of EV71 and HIV-1 are covered by receptorbinding proteins that make up either icosahedral capsids or envelope spikes, both of which mediate specific and multivalent interactions with the host cell membranes. The multivalency concept can be successfully applied in reverse to block viral entry, as shown here by the identification of 33 (AL-518) as the most potent member of an expanding family of antiviral tetrapodal Trp derivatives. This compound stands out as an important novel prototype for further development of similar tripodal and tetrapodal molecules with the ability to block the cellular entry of other viruses that share common structural features on their external surfaces. 


\section{EXPERIMENTAL SECTION}

Synthesis. General Chemistry Procedures. Commercial reagents and solvents were used as received from the suppliers without further purification unless otherwise stated. The solvents used in some reactions were dried prior to use. Dry dimethylformamide (DMF) was commercially available (Aldrich).

Analytical thin-layer chromatography (TLC) was performed on aluminum plates precoated with silica gel $60\left(\mathrm{~F}_{254}, 0.20 \mathrm{~mm}\right)$. Products were visualized using an ultraviolet lamp (254 and $365 \mathrm{~nm}$ ) or by heating after treatment with a $5 \%$ solution of phosphomolybdic acid (PMA) or vanillin in ethanol.

The compounds were purified by (a) high-performance flash chromatography (HPFC) with an "Isolera One" (Biotage) system in reverse phase using water/acetonitrile (100:0-0:100) as the eluent, (b) flash column chromatography on silica gel (60 Merck 230-400 mesh), (c) preparative centrifugal circular thin-layer chromatography (CCTLC) on a Chromatotron (Kiesegel 60 PF254 gipshaltig, Merck) with a layer thickness of $1 \mathrm{~mm}$ and a flow rate of $2-4 \mathrm{~mL} / \mathrm{min}$.

For HPLC analysis, an Agilent Technologies 1120 Compact LC with a reverse-phase column ACE 5 C18-300 $(4.6 \mathrm{~mm} \times 150 \mathrm{~mm}, 3.5$ $\mu \mathrm{m})$ equipped with a photodiode array (PDA) detector was used. Acetonitrile was used as mobile phase A, and water with $0.05 \%$ of trifluoroacetic acid (TFA) was used as mobile phase B with a flow rate of $1 \mathrm{~mL} \cdot \mathrm{min}^{-1}$. All retention times are quoted in minutes, and the gradients are specified for each compound in the experimental data.

For high-resolution mass spectrometry (HRMS), an Agilent 6520 Accurate Mass quadrupole time-of-flight (QTOF) platform coupled with LC/MS and equipped with an electrospray interface (ESI) working in the positive-ion $\left(\mathrm{ESI}^{+}\right)$and negative-ion $\left(\mathrm{ESI}^{-}\right)$modes was used.

NMR spectra $\left({ }^{1} \mathrm{H},{ }^{13} \mathrm{C}\right.$ NMR $)$ were recorded on Varian UNIT INOVA-300 (300 MHz), Bruker AVANCE $300(300$ and $75 \mathrm{MHz})$, Varian INOVA-400 (400 and $100 \mathrm{MHz}$ ), Varian MERCURY-400 (400 and $100 \mathrm{MHz}$ ), and Varian-500 (500 and $125 \mathrm{MHz}$ ) spectrometers using $\left(\mathrm{CD}_{3}\right)_{2} \mathrm{SO}$ and $\mathrm{CDCl}_{3}$ as solvents. Chemical shift $(\delta)$ values are reported in parts per million (ppm) relative to tetramethylsilane (TMS) in ${ }^{1} \mathrm{H}$ and $\mathrm{CDCl}_{3}(\delta=77.0)$ in ${ }^{13} \mathrm{C}$ NMR. Coupling constants $(J$ values) are reported in hertz $(\mathrm{Hz})$ and multiplicities of signals are indicated by the following symbol: $s$ (singlet), $\mathrm{d}$ (doublet), $\mathrm{t}$ (triplet), $\mathrm{q}$ (quadruplet), $\mathrm{m}$ (multiplet), and bs (broad singlet). Some two-dimensional spectra (correlation spectroscopy (COSY), heteronuclear single quantum coherence (HSQC), and heteronuclear multiple bond correlation (HMBC)) were obtained to identify the structure. The final compounds were lyophilized using a Telstar Lyoquest- 85 system. They had purities $>95 \%$ based on HPLC, LC/MS, and ${ }^{1} \mathrm{H}$ NMR analyses.

General Coupling Procedure for the Synthesis of OMeProtected Tripodal and Tetrapodal Trp Derivatives. To a solution in DMF $(20 \mathrm{~mL})$ containing the corresponding tri- or tetrapodal polyacid $10^{45}$ or $17^{46,47}(1 \mathrm{mmol})$, hexafluorophosphate azabenzotriazole tetramethyl uronium (HATU) (1.2 equiv of each carboxylic acid group), and the corresponding Trp C7 or C2/C7 aryl intermediate (1.2 equiv of each carboxylic acid group), $\mathrm{N}, \mathrm{N}$ diisopropylethylamine (DIPEA) (2.4 equiv of each carboxylic acid group) was added. The reaction mixture was stirred at $30{ }^{\circ} \mathrm{C}$ for $24 \mathrm{~h}$ and then evaporated to dryness. The residue was dissolved in ethyl acetate $(20 \mathrm{~mL})$ and washed successively with aqueous solutions of citric acid $(10 \%)(3 \times 20 \mathrm{~mL})$, saturated $\mathrm{NaHCO}_{3}(3 \times 20 \mathrm{~mL})$, and brine $(3 \times 20 \mathrm{~mL})$. The organic phase was dried over anhydrous $\mathrm{Na}_{2} \mathrm{SO}_{4}$, filtered, and evaporated to dryness. The residue was purified on a centrifugal thin-layer chromatography (CCTLC) purification system on normal phase using methanol/dichloromethane (0:100$20: 80)$ or hexane/ethyl acetate $(100: 0-0: 100)$ as the eluent to give the corresponding tri- or tetrapodal Trp intermediate.

General Procedure for Methyl Ester Deprotection. To a solution containing the corresponding methyl ester derivative (1.0 mmol) in tetrahydrofuran (THF) $(10 \mathrm{~mL})$ at $0{ }^{\circ} \mathrm{C}$ (ice bath), a solution of $\mathrm{LiOH} \cdot \mathrm{H}_{2} \mathrm{O}$ (2 equiv for each methyl ester group) in water $(2 \mathrm{~mL})$ was added, and the mixture was stirred at $30{ }^{\circ} \mathrm{C}$ overnight.
Then, $1 \mathrm{~N}$ hydrochloric acid aqueous solution was added to reach $\mathrm{pH}$ $\sim 2$, and volatiles were evaporated to dryness. The residue was dissolved in isobutanol $(15 \mathrm{~mL})$ and washed with brine $(3 \times 10 \mathrm{~mL})$ and water $(3 \times 10 \mathrm{~mL})$. The organic phase was dried over anhydrous $\mathrm{Na}_{2} \mathrm{SO}_{4}$, filtered, and evaporated to dryness. The residue was purified with a Biotage high-performance flash chromatography (HPFC) purification system on reverse phase using water/acetonitrile (100:0$0: 100)$ as the eluent, frozen, and lyophilized, yielding the product as a fluffy powder.

(S)-Methyl 2-((tert-Butoxycarbonyl)amino)-3-(7-(4,4,5,5-tetramethyl-1,3,2-dioxaborolan-2-yl)-1H-indol-3-yl)propanoate (3). Commercially available $N$-Boc-L-tryptophan methyl ester 1 (600 $\mathrm{mg}, 1.88 \mathrm{mmol}, 1.00$ equiv), (1,5-cyclooctadiene)(methoxy)iridium(I) dimer $\left([\operatorname{Ir}(\operatorname{cod}) \mathrm{OMe}]_{2}\right)(31.2 \mathrm{mg}, 0.047 \mathrm{mmol}, 2.5 \mathrm{~mol} \%)$, bis(pinacolato)diboron ( $1.19 \mathrm{~g}, 4.70 \mathrm{mmol}, 2.5$ equiv), and 4,4'-ditert-butyl-2,2'-bipyridine (d'bpy) (25.2 mg, $0.094 \mathrm{mmol}, 5 \mathrm{~mol} \%)$ were sealed in a dry reaction vial (microwave reactor vessel can also be used) equipped with a magnetic stirring bar under an argon atmosphere, and anhydrous tetrahydrofuran $(5 \mathrm{~mL})$ was added. The resulting red solution was stirred at $60{ }^{\circ} \mathrm{C}$ for $12 \mathrm{~h}$. After cooling to room temperature and removal of volatiles under reduced pressure, the subsequent brown residue (intermediate 2) was dissolved in $\mathrm{MeOH} / \mathrm{THF}(5 / 4 \mathrm{~mL})$ and bismuth(III) acetate $(145.4 \mathrm{mg}, 0.38$ $\mathrm{mmol}, 20 \mathrm{~mol} \%)$ was added. The mixture was stirred under argon at $80^{\circ} \mathrm{C}$ for $12 \mathrm{~h}$, then cooled to room temperature, and filtered through Whatman filter paper 42 that was washed three times with ethyl acetate. The filtrate was washed with brine $(50 \mathrm{~mL})$, and the organic layer was dried over anhydrous $\mathrm{Na}_{2} \mathrm{SO}_{4}$, filtered, and concentrated under reduced pressure. The resulting brown residue was purified by flash column chromatography on silica gel using hexane/ethyl acetate (4:1) as the eluent to afford 7-borotryptophan derivative $3(451 \mathrm{mg}$, $47 \%)$ as a white powder. The melting point and spectroscopic data of 3 were consistent with those found in the literature. ${ }^{41}$

General Procedure for C7 Arylation of Indole. A dry reaction vial (microwave reactor vessel can also be used) was charged sequentially with 7-borotryptophan $3^{41}(150 \mathrm{mg}, 0.34 \mathrm{mmol}, 1.00$ equiv), tris(dibenzylideneacetone) dipalladium $(0) \quad\left(\mathrm{Pd}_{2}(\mathrm{dba})_{3}\right) \quad(15$ $\mathrm{mg}, 0.02 \mathrm{mmol}, 5 \mathrm{~mol} \%)$, SPhos ( $28 \mathrm{mg}, 0.07 \mathrm{mmol}, 10 \mathrm{~mol} \%$ ), and tribasic potassium phosphate $(215 \mathrm{mg}, 1.01 \mathrm{mmol}, 2.00$ equiv); sealed; and placed under an argon atmosphere. Then, anhydrous toluene $(3 \mathrm{~mL})$ and the corresponding aryl bromide (1.20 equiv) were added via a syringe. The reaction mixture was stirred at $80{ }^{\circ} \mathrm{C}$ for $12 \mathrm{~h}$. After being cooled to room temperature, the resulting suspension was filtered through Whatman filter paper 42 that was washed three times with ethyl acetate $(20 \mathrm{~mL})$. The filtrate was washed with brine $(3 \times 20 \mathrm{~mL})$, and the organic layer was dried over anhydrous $\mathrm{Na}_{2} \mathrm{SO}_{4}$, filtered, and concentrated under reduced pressure. The resulting brown residue was purified by CCTLC using hexane/ethyl acetate $(7: 3)$ as the eluent to afford the corresponding $\mathrm{C} 7$ aryl tryptophan intermediate.

(S)-Methyl 2-((tert-Butoxycarbonyl)amino)-3-(7-(3-methoxycarbonyl-1-phenyl)-1H-indol-3-yl)propanoate (4). Following the general C7 arylation procedure, compound $3^{41}(150 \mathrm{mg}, 0.34 \mathrm{mmol}, 1.00$ equiv), tris(dibenzylideneacetone)dipalladium $\left(\mathrm{Pd}_{2}(\mathrm{dba})_{3}\right)(15 \mathrm{mg}$, $0.02 \mathrm{mmol}, 5 \mathrm{~mol} \%)$, SPhos $(28 \mathrm{mg}, 0.07 \mathrm{mmol}, 10 \mathrm{~mol} \%)$, tribasic potassium phosphate (215 $\mathrm{mg}, 1.01 \mathrm{mmol}, 2.00$ equiv), and methyl 3 bromobenzoate $(87 \mathrm{mg}, 0.40 \mathrm{mmol}, 1.20$ equiv) afforded $4(215 \mathrm{mg}$, $70 \%)$ as a white amorphous solid. ${ }^{1} \mathrm{H}$ NMR $\left(300 \mathrm{MHz}, \mathrm{CDCl}_{3}\right) \delta$ : $8.36\left(\mathrm{~s}, 1 \mathrm{H}, \mathrm{NH}-1^{i} \operatorname{Trp}\right), 8.33(\mathrm{~m}, 1 \mathrm{H}, \mathrm{Ar}), 8.09(\mathrm{dt}, J=7.8,1.5 \mathrm{~Hz}$ $1 \mathrm{H}, \mathrm{Ar}), 7.83(\mathrm{dt}, J=7.8,1.5 \mathrm{~Hz}, 1 \mathrm{H}, \mathrm{Ar}), 7.60(\mathrm{~m}, 2 \mathrm{H}, \mathrm{Ar}), 7.26(\mathrm{~m}$, $2 \mathrm{H}, \mathrm{Ar}), 7.07(\mathrm{~m}, 1 \mathrm{H}, \mathrm{Ar}), 5.14(\mathrm{~d}, J=8.3 \mathrm{~Hz}, 1 \mathrm{H}, \mathrm{NHCO}), 4.70(\mathrm{~m}$, $1 \mathrm{H}, \alpha$-CHTrp), $3.97\left(\mathrm{~s}, 3 \mathrm{H}, \mathrm{OCH}_{3}\right), 3.73\left(\mathrm{~s}, 3 \mathrm{H}, \mathrm{OCH}_{3}\right), 3.35(\mathrm{t}, J=$ $\left.4.4 \mathrm{~Hz}, 2 \mathrm{H}, \beta-\mathrm{CH}_{2} \mathrm{Trp}\right), 1.46\left(\mathrm{~s}, 9 \mathrm{H}, \mathrm{CH}_{3}\right)$. HPLC [gradient: $\mathrm{H}_{2} \mathrm{O}$ / $\mathrm{MeCN} 10-100 \%$ of $\mathrm{MeCN}$ in $10 \mathrm{~min}$ ]: $9.700 \mathrm{~min}$.

(S)-Methyl 2-((tert-Butoxycarbonyl)amino)-3-(7-(4-methoxycarbonyl-1-phenyl)-1H-indol-3-yl)propanoate (5). Following the general C7 arylation procedure, 7-borotryptophan $3^{41}(170 \mathrm{mg}, 0.38$ mmol, 1.00 equiv), tris(dibenzylideneacetone)dipalladium $\left(\operatorname{Pd}_{2}(\mathrm{dba})_{3}\right)(17.53 \mathrm{mg}, 0.02 \mathrm{mmol}, 5 \mathrm{~mol} \%)$, SPhos (16 mg, 0.04 $\mathrm{mmol}, 10 \mathrm{~mol} \%)$, tribasic potassium phosphate $(163 \mathrm{mg}, 0.77 \mathrm{mmol}$, 
2.00 equiv), and methyl 4-bromobenzoate ( $99 \mathrm{mg}, 0.46 \mathrm{mmol}, 1.20$ equiv) afforded $5(215 \mathrm{mg}, 70 \%)$ as a white amorphous solid. ${ }^{1} \mathrm{H}$ NMR $\left(400 \mathrm{MHz}, \mathrm{CDCl}_{3}\right) \delta: 8.33\left(\mathrm{~s}, 1 \mathrm{H}, \mathrm{NH}-1^{i} \operatorname{Trp}\right), 8.17(\mathrm{~m}, 2 \mathrm{H}$, $\mathrm{Ar}), 7.70(\mathrm{~d}, J=8.1 \mathrm{~Hz}, 2 \mathrm{H}, \mathrm{Ar}), 7.59(\mathrm{dd} J=7.2,1.8 \mathrm{~Hz}, 1 \mathrm{H}, \mathrm{Ar})$, $7.23(\mathrm{~m}, 1 \mathrm{H}, \mathrm{Ar}), 7.05(\mathrm{~m}, 1 \mathrm{H}, \mathrm{Ar}), 5.10(\mathrm{~d}, J=8.2 \mathrm{~Hz}, 1 \mathrm{H}, \mathrm{NHCO})$, $4.67\left(\mathrm{~m}, 1 \mathrm{H}, \alpha\right.$-CHTrp), $3.96\left(\mathrm{~s}, 3 \mathrm{H}, \mathrm{OCH}_{3}\right), 3.71\left(\mathrm{~s}, 3 \mathrm{H}, \mathrm{OCH}_{3}\right)$, $3.32\left(\mathrm{~m}, 2 \mathrm{H}, \beta-\mathrm{CH}_{2} \mathrm{Trp}\right), 1.43\left(\mathrm{~s}, 9 \mathrm{H}, \mathrm{CH}_{3}\right)$. HPLC [gradient: $\mathrm{H}_{2} \mathrm{O}$ / $\mathrm{MeCN}, 10-100 \%$ of $\mathrm{MeCN}$, in $10 \mathrm{~min}$ ]: $9.800 \mathrm{~min}$.

(S)-Methyl 2-((tert-Butoxycarbonyl)amino)-3-(7-(3,5-dimethoxycarbonyl-1-phenyl)-1H-indol-3-yl)propanoate (6). Following the general C7 arylation procedure, 7-borotryptophan $3^{41}(150 \mathrm{mg}$, $0.34 \mathrm{mmol}, 1$ equiv), tris(dibenzylideneacetone)dipalladium $\left(\operatorname{Pd}_{2}(\mathrm{dba})_{3}\right)(15.46 \mathrm{mg}, 16.9 \mu \mathrm{mol}, 5 \mathrm{~mol} \%)$, SPhos $(28 \mathrm{mg}, 67$ $\mu \mathrm{mol}, 10 \mathrm{~mol} \%)$, tribasic potassium phosphate $(215 \mathrm{mg}, 1.01 \mathrm{mmol}$, 3.00 equiv), and dimethyl 5-bromoisophthalate $(110 \mathrm{mg}, 0.40 \mathrm{mmol}$, 1.20 equiv) afforded $6(96 \mathrm{mg}, 56 \%)$ as a white amorphous solid. ${ }^{1} \mathrm{H}$ NMR $\left(400 \mathrm{MHz}, \mathrm{CDCl}_{3}\right) \delta: 8.68(\mathrm{t}, J=1.6 \mathrm{~Hz}, 1 \mathrm{H}, \mathrm{Ar}), 8.48(\mathrm{~d}, J=$ $1.7 \mathrm{~Hz}, 2 \mathrm{H}, \mathrm{Ar}$ ), 8.38 (bs, $\left.1 \mathrm{H}, \mathrm{NH}-1^{i} \operatorname{Trp}\right), 7.60$ (dd, $J=7.4,1.6 \mathrm{~Hz}$, 1H, Ar), 7.28-7.20 (m, 2H, Ar), 7.06 (d, J = 2.4 Hz, 1H, Ar), 5.11 (d, $J=8.2 \mathrm{~Hz}, 1 \mathrm{H}, \mathrm{NHCO}), 4.72-4.64(\mathrm{~m}, 1 \mathrm{H}, \alpha$-CHTrp), $3.97(\mathrm{~s}, 6 \mathrm{H}$, $\left.\mathrm{OCH}_{3}\right), 3.70\left(\mathrm{~s}, 3 \mathrm{H}, \mathrm{OCH}_{3}\right), 3.34\left(\mathrm{~m}, 2 \mathrm{H}, \beta-\mathrm{CH}_{2} \mathrm{Trp}\right), 1.43(\mathrm{~s}, 9 \mathrm{H}$, $\mathrm{CH}_{3}$ ). HPLC [gradient: $\mathrm{H}_{2} \mathrm{O} / \mathrm{MeCN}, 10-100 \%$ of $\mathrm{MeCN}$ in 10 $\min$ ]: 9.613 min.

(S)-Methyl 2-Amino-3-(7-(3-methoxycarbonyl-1-phenyl)-1Hindol-3-yl)propanoate (7). To a cold $\left(0{ }^{\circ} \mathrm{C}\right)$ solution of compound $4(207 \mathrm{mg}, 0.46 \mathrm{mmol})$ in dichloromethane $(10 \mathrm{~mL})$, TFA $(0.5 \mathrm{~mL})$ was added. The mixture was stirred at room temperature for $6 \mathrm{~h}$. Then, volatiles were evaporated to dryness and the residue was coevaporated successively with methanol and dichloromethane to afford compound 7 (245 mg, quant.) in the salt form. ${ }^{1} \mathrm{H}$ NMR (300 $\mathrm{MHz}$, dimethyl sulfoxide (DMSO)- $\left.d_{6}\right) \delta: 11.10$ (s, $\left.1 \mathrm{H}, \mathrm{NH}-1^{i} \mathrm{Trp}\right)$, $8.39\left(\mathrm{~s}, 3 \mathrm{H}, \mathrm{NH}_{3}{ }^{+}\right), 8.17(\mathrm{t}, J=1.8 \mathrm{~Hz}, 1 \mathrm{H}, \mathrm{Ar}), 8.01(\mathrm{dt}, J=7.8,1.5$ $\mathrm{Hz}, 1 \mathrm{H}, \mathrm{Ar}), 7.88$ (d, $J=7.8 \mathrm{~Hz}, 1 \mathrm{H}, \mathrm{Ar}), 7.69$ (t, $J=7.8 \mathrm{~Hz}, 1 \mathrm{H}, \mathrm{Ar})$, 7.54 (m, 1H, Ar), 7.25 (d, J = 2.6 Hz, 1H, Ar), 7.17 (m, 2H, Ar), 4.36 $\left(\mathrm{m}, 1 \mathrm{H}, \alpha\right.$-CHTrp), $3.89\left(\mathrm{~s}, 3 \mathrm{H}, \mathrm{OCH}_{3}\right), 3.73\left(\mathrm{~s}, 3 \mathrm{H}, \mathrm{OCH}_{3}\right), 3.31$ (d, $J=6.0 \mathrm{~Hz}, 2 \mathrm{H}, \beta-\mathrm{CH}_{2}$ Trp). HPLC [gradient: $\mathrm{H}_{2} \mathrm{O} / \mathrm{MeCN}, 10-$ $100 \%$ of $\mathrm{MeCN}$ in $10 \mathrm{~min}$ ]: $6.724 \mathrm{~min}$.

(S)-Methyl 2-Amino-3-(7-(4-methoxycarbonyl-1-phenyl)-1Hindol-3-yl)propanoate (8). A cold $\left(0{ }^{\circ} \mathrm{C}\right)$ solution of compound 5 $(120 \mathrm{mg}, 0.27 \mathrm{mmol})$ in dichloromethane $(10 \mathrm{~mL})$ was treated with TFA $(0.5 \mathrm{~mL})$ as described for 7 to afford $8(122 \mathrm{mg}, 99 \%)$ in the salt form. ${ }^{1} \mathrm{H}$ NMR (300 MHz, DMSO- $\left.d_{6}\right) \delta: 11.08(\mathrm{~d}, J=2.8 \mathrm{~Hz}, 1 \mathrm{H}$, NH- $1^{i}$ Trp $), 8.40\left(\mathrm{~s}, 3 \mathrm{H}, \mathrm{NH}_{3}{ }^{+}\right), 8.10(\mathrm{~d}, J=8.3 \mathrm{~Hz}, 2 \mathrm{H}, \mathrm{Ar}), 7.78$ (d, $J=8.3 \mathrm{~Hz}, 2 \mathrm{H}, \mathrm{Ar}), 7.57(\mathrm{~d}, J=7.6 \mathrm{~Hz}, 1 \mathrm{H}, \mathrm{Ar}), 7.20(\mathrm{~m}, 3 \mathrm{H}, \mathrm{Ar})$, $4.34\left(\mathrm{~m}, 1 \mathrm{H}, \alpha\right.$-CHTrp), $3.90\left(\mathrm{~s}, 3 \mathrm{H}, \mathrm{OCH}_{3}\right), 3.72\left(\mathrm{~s}, 3 \mathrm{H}, \mathrm{OCH}_{3}\right)$, $3.31\left(\mathrm{~d}, J=6.2 \mathrm{~Hz}, 2 \mathrm{H}, \beta-\mathrm{CH}_{2} \mathrm{Trp}\right)$. HPLC [gradient: $\mathrm{H}_{2} \mathrm{O} / \mathrm{MeCN}$, $10-100 \%$ of $\mathrm{MeCN}$ in $10 \mathrm{~min}]: 6.601 \mathrm{~min}$.

(S)-Methyl 2-Amino-3-(7-(3,5-dimethoxycarbonyl-1-phenyl)-1Hindol-3-yl)propanoate (9). A cold solution $\left(0{ }^{\circ} \mathrm{C}\right)$ of compound 6 $(170 \mathrm{mg}, 0.33 \mathrm{mmol})$ in dichloromethane $(15 \mathrm{~mL})$ was treated with TFA $(1 \mathrm{~mL})$ as described for 7 to afford $9(172.3 \mathrm{mg}$, quant.) in the salt form. ${ }^{1} \mathrm{H}$ NMR (300 MHz, DMSO- $\left.d_{6}\right) \delta: 11.19(\mathrm{~d}, J=2.9 \mathrm{~Hz}$, $\left.1 \mathrm{H}, \mathrm{NH}-1^{i} \mathrm{Trp}\right), 8.51(\mathrm{t}, J=1.6 \mathrm{~Hz}, 1 \mathrm{H}, \mathrm{Ar}), 8.39\left(\mathrm{~s}, 3 \mathrm{H}, \mathrm{NH}_{3}{ }^{+}\right), 8.37$ $(\mathrm{d}, J=1.6 \mathrm{~Hz}, 2 \mathrm{H}, \mathrm{Ar}), 7.59$ (dd, $J=6.9,2.2 \mathrm{~Hz}, 1 \mathrm{H}, \mathrm{Ar}), 7.29$ (d, $J=$ $2.5 \mathrm{~Hz}, 1 \mathrm{H}, \mathrm{Ar}$ ), 7.24-7.16 (m, 2H, Ar), 4.35 (m, $\alpha$-CHTrp), 3.92 (s, $\left.6 \mathrm{H}, \mathrm{OCH}_{3}\right), 3.73\left(\mathrm{~s}, 3 \mathrm{H}, \mathrm{OCH}_{3}\right), 3.32\left(\mathrm{~m}, 2 \mathrm{H}, \beta-\mathrm{CH}_{2} \mathrm{Trp}\right)$. HPLC [gradient: $\mathrm{H}_{2} \mathrm{O} / \mathrm{MeCN}, 10-100 \%$ of $\mathrm{MeCN}$ in $10 \mathrm{~min}$ ]: $6.798 \mathrm{~min}$.

Tripodal 11. Following the general coupling procedure, a solution of the tripodal polyacid $10^{45}$ (16 mg, $0.59 \mu \mathrm{mol}, 1.00$ equiv), HATU ( $81 \mathrm{mg}, 0.21 \mathrm{mmol}, 3.60$ equiv), and intermediate 7 (100 mg, 0.21 mmol, 3.60 equiv) in dry DMF $(20 \mathrm{~mL})$ was treated with DIPEA ( 74 $\mu \mathrm{L}, 0.49 \mathrm{mmol}, 7.20$ equiv) to afford compound $11(37 \mathrm{mg}, 48 \%)$ as an amorphous white solid. ${ }^{1} \mathrm{H}$ NMR $\left(400 \mathrm{MHz}, \mathrm{CDCl}_{3}\right) \delta: 8.69$ (d, J $\left.=2.6 \mathrm{~Hz}, 3 \mathrm{H}, \mathrm{NH}-1^{i} \operatorname{Trp}\right), 8.25(\mathrm{t}, J=1.8 \mathrm{~Hz}, 3 \mathrm{H}, \mathrm{Ar}), 8.00(\mathrm{dt}, J=$ 7.8, 1.4 Hz, 3H, Ar), 7.75 (dt, $J=7.8,1.4 \mathrm{~Hz}, 3 \mathrm{H}, \mathrm{Ar}), 7.57-7.39(\mathrm{~m}$, $6 \mathrm{H}, \mathrm{Ar}), 7.22-7.11(\mathrm{~m}, 5 \mathrm{H}, \mathrm{Ar}), 6.94(\mathrm{~d}, J=2.4 \mathrm{~Hz}, 3 \mathrm{H}, \mathrm{NHCO})$, $4.74(\mathrm{~m}, 3 \mathrm{H}, \alpha-\mathrm{CHTrp}), 3.87\left(\mathrm{~s}, 9 \mathrm{H}, \mathrm{OCH}_{3}\right), 3.62\left(\mathrm{~s}, 9 \mathrm{H}, \mathrm{OCH}_{3}\right)$, $3.23\left(\mathrm{~m}, 6 \mathrm{H}, \beta-\mathrm{CH}_{2} \mathrm{Trp}\right), 2.06-1.91\left(\mathrm{~m}, 12 \mathrm{H}, \mathrm{OCH}_{2}\right)$. HPLC [gradient: $\mathrm{H}_{2} \mathrm{O} / \mathrm{MeCN}, 40-100 \%$ of $\mathrm{MeCN}$ in $10 \mathrm{~min}$ ]: $9.110 \mathrm{~min}$.
Tripodal 12. Following the general coupling procedure, a solution of the tripodal polyacid $10^{45}$ ( $7 \mathrm{mg}, 0.24 \mu \mathrm{mol}, 1.00$ equiv), HATU (33 mg, $0.09 \mathrm{mmol}, 3.60$ equiv), and intermediate 8 (40 mg, 0.09 mmol, 3.60 equiv) in dry DMF $(20 \mathrm{~mL})$ was treated with DIPEA (30 $\mu \mathrm{L}, 0.17 \mathrm{mmol}, 7.20$ equiv) to afford compound $12(14 \mathrm{mg}, 48 \%)$ as an amorphous white solid. ${ }^{1} \mathrm{H}$ NMR $\left(400 \mathrm{MHz}, \mathrm{CDCl}_{3}\right) \delta: 8.68$ (s, $\left.3 \mathrm{H}, \mathrm{NH}-1^{i} \operatorname{Trp}\right), 8.11(\mathrm{~d}, J=8.0 \mathrm{~Hz}, 6 \mathrm{H}, \mathrm{Ar}), 7.64(\mathrm{~d}, J=8.0 \mathrm{~Hz}, 6 \mathrm{H}$, Ar), 7.48 (dd, $J=7.3,1.7 \mathrm{~Hz}, 3 \mathrm{H}, \mathrm{Ar}), 7.18(\mathrm{~m}, 6 \mathrm{H}, \mathrm{Ar}), 6.95$ (d, $J=$ $2.4 \mathrm{~Hz}, 3 \mathrm{H}, \mathrm{Ar}$ ), 6.29 (d, J = 7.9 Hz, 3H, NHCO), $4.83(\mathrm{~m}, 3 \mathrm{H}, \alpha-$ CHTrp), $3.93\left(\mathrm{~s}, 9 \mathrm{H}, \mathrm{OCH}_{3}\right), 3.65\left(\mathrm{~s}, 9 \mathrm{H}, \mathrm{OCH}_{3}\right), 3.24(\mathrm{~m}, 6 \mathrm{H}, \beta-$ $\mathrm{CH}_{2}$ Trp), 2.11-2.02 (m, $\left.12 \mathrm{H}, \mathrm{OCH}_{2}\right)$. HPLC [gradient: $\mathrm{H}_{2} \mathrm{O}$ / $\mathrm{MeCN}, 40-100 \%$ of $\mathrm{MeCN}$ in $10 \mathrm{~min}$ ]: $9.210 \mathrm{~min}$.

Tripodal 13. Following the general coupling procedure, a solution of the tripodal polyacid $\mathbf{1 0}^{45}(15 \mathrm{mg}, 0.05 \mathrm{mmol}, 1.00$ equiv), HATU (76 mg, $0.20 \mathrm{mmol}, 3.60$ equiv), and intermediate 9 (105 mg, 0.21 mmol, 3.60 equiv) in dry DMF $(20 \mathrm{~mL})$ was treated with DIPEA (69 $\mu \mathrm{L}, 0.40 \mathrm{mmol}, 7.20$ equiv) to afford compound $13(57 \mathrm{mg}, 69 \%)$ as an amorphous white solid. ${ }^{1} \mathrm{H}$ NMR $\left(400 \mathrm{MHz}, \mathrm{CDCl}_{3}\right) \delta: 8.86(\mathrm{~d}, J$ $\left.=2.5 \mathrm{~Hz}, 3 \mathrm{H}, \mathrm{NH}-1^{i} \operatorname{Trp}\right), 8.61(\mathrm{t}, J=1.6 \mathrm{~Hz}, 3 \mathrm{H}, \mathrm{Ar}), 8.41(\mathrm{~d}, J=1.7$ $\mathrm{Hz}, 6 \mathrm{H}, \mathrm{Ar}$ ), 7.49 (dd, $J=5.2,3.8 \mathrm{~Hz}, 3 \mathrm{H}, \mathrm{Ar}), 7.15$ (q, $J=2.6,1.7$ $\mathrm{Hz}, 6 \mathrm{H}, \mathrm{Ar}), 6.97(\mathrm{~d}, J=2.4 \mathrm{~Hz}, 3 \mathrm{H}, \mathrm{Ar}), 6.41(\mathrm{~d}, J=7.9 \mathrm{~Hz}, 3 \mathrm{H}$, $\mathrm{NHCO}), 4.83\left(\mathrm{~m}, 3 \mathrm{H}, \alpha\right.$-CHTrp), $3.90\left(\mathrm{~s}, 18 \mathrm{H}, \mathrm{OCH}_{3}\right), 3.63(\mathrm{~s}, 9 \mathrm{H}$, $\left.\mathrm{OCH}_{3}\right), 3.23\left(\mathrm{~m}, 6 \mathrm{H}, \beta-\mathrm{CH}_{2} \mathrm{Trp}\right), 2.10\left(\mathrm{~m}, 12 \mathrm{H}, \mathrm{CH}_{2}\right)$. HPLC [gradient: $\mathrm{H}_{2} \mathrm{O} / \mathrm{MeCN}, 40-100 \%$ of $\mathrm{MeCN}$ in $10 \mathrm{~min}$ ]: $9.300 \mathrm{~min}$.

Tripodal 14. Following the general procedure for methyl ester deprotection, intermediate 11 (37 mg, $0.03 \mathrm{mmol}, 1.00$ equiv) and $\mathrm{LiOH} \cdot \mathrm{H}_{2} \mathrm{O}$ (16 mg, $0.37 \mathrm{mmol}, 12.00$ equiv) gave 14 (38 mg, quant.) as an amorphous white solid. ${ }^{1} \mathrm{H}$ NMR $\left(500 \mathrm{MHz}, \mathrm{DMSO}-d_{6}\right) \delta$ : 10.82 (s, 3H, NH-1 ${ }^{i} \operatorname{Trp}$ ), 8.28 (d, J = 7.7 Hz, 3H, NHCO), 8.13 (s, $3 \mathrm{H}, \mathrm{Ar}), 7.95(\mathrm{~d}, J=7.6 \mathrm{~Hz}, 3 \mathrm{H}, \mathrm{Ar}), 7.82(\mathrm{~d}, J=7.6 \mathrm{~Hz}, 3 \mathrm{H}, \mathrm{Ar})$, $7.61(\mathrm{t}, J=7.7 \mathrm{~Hz}, 3 \mathrm{H}, \mathrm{Ar}), 7.55(\mathrm{~m}, 3 \mathrm{H}, \mathrm{Ar}), 7.14(\mathrm{~d}, J=2.5 \mathrm{~Hz}, 3 \mathrm{H}$, Ar), 7.10 (d, $J=4.6 \mathrm{~Hz}, 4 \mathrm{H}, \mathrm{Ar}), 4.46$ (m, 3H $\alpha$-CHTrp), 3.18 (m, $\left.3 \mathrm{H}, \mathrm{OCH}_{3}\right), 3.03\left(\mathrm{~m}, 6 \mathrm{H}, \beta-\mathrm{CH}_{2} \mathrm{Trp}\right), 2.04\left(\mathrm{~m}, 12 \mathrm{H}, \mathrm{OCH}_{2}\right) .{ }^{13} \mathrm{C}$ NMR $\left(126 \mathrm{MHz}\right.$, DMSO-d $\left.d_{6}\right) \delta: 173.4,170.7,167.4,139.1,133.2$, $132.6,131.5,129.3,129.0,128.3,128.0,124.6,124.3,121.3,119.2$, 118.1, 110.5, 93.3, 65.0, 53.2, 45.9, 30.7, 29.3, 27.1. HPLC [gradient: $\mathrm{H}_{2} \mathrm{O} / \mathrm{MeCN}, 10-100 \%$ of $\mathrm{MeCN}$ in $10 \mathrm{~min}$ ]: $7.510 \mathrm{~min}$. HRMS $\left(\mathrm{ESI}^{-}\right) \mathrm{m} / z$ : calcd for $\mathrm{C}_{64} \mathrm{H}_{57} \mathrm{~N}_{7} \mathrm{O}_{17} 1195.38109$; found 1195.38089 .

Tripodal 15. Following the general procedure for methyl ester deprotection, intermediate $12(15 \mathrm{mg}, 0.01 \mathrm{mmol}, 1.00$ equiv) and $\mathrm{LiOH} \cdot \mathrm{H}_{2} \mathrm{O}$ ( $8 \mathrm{mg}, 0.18 \mathrm{mmol}, 18.00$ equiv) gave $15(7 \mathrm{mg}, 54 \%)$ as an amorphous white solid. ${ }^{1} \mathrm{H}$ NMR (500 MHz, DMSO- $\left.d_{6}\right) \delta: 10.83$ (d, $J=2.5 \mathrm{~Hz}, 3 \mathrm{H}, \mathrm{NH}-1^{i} \mathrm{Trp}$ ), 8.26 (d, $J=7.7 \mathrm{~Hz}, 3 \mathrm{H}, \mathrm{NHCO}$ ), 8.05 (d, $J=7.8 \mathrm{~Hz}, 6 \mathrm{H}, \mathrm{Ar}), 7.72(\mathrm{~d}, J=7.8 \mathrm{~Hz}, 4 \mathrm{H}, \mathrm{Ar}), 7.57$ (d, $J=7.8$ $\mathrm{Hz}, 4 \mathrm{H}, \mathrm{Ar}), 7.15(\mathrm{~m}, 5 \mathrm{H}, \mathrm{Ar}), 7.10(\mathrm{t}, J=7.5 \mathrm{~Hz}, 4 \mathrm{H}), 4.48(\mathrm{~m}, 3 \mathrm{H}$, $\alpha$-CHTrp), 3.18 (dd, $\left.J=14.3,7.3 \mathrm{~Hz}, 3 \mathrm{H}, \beta-\mathrm{CH}_{2} \mathrm{Trp}\right), 3.03$ (dd, $J=$ $14.7,8.4 \mathrm{~Hz}, 3 \mathrm{H}, \beta-\mathrm{CH}_{2}$ Trp $), 2.12-1.92\left(\mathrm{~m}, 12 \mathrm{H}, \mathrm{OCH}_{2}\right), 1.24(\mathrm{~m}$, $\left.4 \mathrm{H}, \mathrm{OCH}_{2}\right) .{ }^{13} \mathrm{C}$ NMR $\left(126 \mathrm{MHz}\right.$, DMSO-d $\left.d_{6}\right) \delta: 173.3,170.6,167.2$, $143.2,133.1,129.9,129.3,128.4,128.3,124.6,124.1,121.4,119.1$, $118.5,110.6,53.2,30.4,29.3,29.0,27.1$. HPLC [gradient: $\mathrm{H}_{2} \mathrm{O} /$ $\mathrm{MeCN}, 10-100 \%$ of $\mathrm{MeCN}$ in $10 \mathrm{~min}$ ]: $6.924 \mathrm{~min}$. HRMS $\left(\mathrm{ESI}^{-}\right)$ $m / z$ : calcd for $\mathrm{C}_{64} \mathrm{H}_{57} \mathrm{~N}_{7} \mathrm{O}_{17} 1195.38109$; found 1195.38042 .

Tripodal 16. Following the general procedure for methyl ester deprotection, intermediate 13 (12 mg, $8.25 \mu \mathrm{mol}, 1.00$ equiv) and $\mathrm{LiOH} \cdot \mathrm{H}_{2} \mathrm{O}(6 \mathrm{mg}, 0.14 \mathrm{mmol}, 18.00$ equiv) gave $16(6.6 \mathrm{mg}, 60 \%)$ as an amorphous white solid. ${ }^{1} \mathrm{H}$ NMR $\left(300 \mathrm{MHz}, \mathrm{DMSO}-d_{6}\right) \delta: 10.92$ (s, 3H, NH-1 $\left.{ }^{i} \mathrm{Trp}\right), 8.48$ (s, 3H, Ar), 8.31 (m, 6, Ar), 8.27 (m, 3H, NHCO), 7.59 (m, 3H, Ar), 7.17 (m, 3H, Ar), 7.13 (s, 6H, Ar), 4.49 $\left(\mathrm{m}, 3 \mathrm{H}, \alpha\right.$-CHTrp), 3.16 (m, 3H, $\beta$ - $\mathrm{CH}_{2}$ Trp), 3.05 (dd, $J=14.3,7.6$ $\left.\mathrm{Hz}, 3 \mathrm{H}, \beta-\mathrm{CH}_{2} \mathrm{Trp}\right), 2.07\left(\mathrm{~m}, 12 \mathrm{H}, \mathrm{OCH}_{2}\right) .{ }^{13} \mathrm{C}$ NMR $(126 \mathrm{MHz}$, DMSO-d $\left.{ }_{6}\right) \delta: 173.4,170.7,167.0,139.4,133.2,132.7,128.6,128.4$, $124.7,123.7,121.4,119.2,118.4,110.7,93.3,64.9,53.2,30.6,29.3$, 27.8 , 27.1. HPLC [gradient: $\mathrm{H}_{2} \mathrm{O} / \mathrm{MeCN}, 10-100 \%$ of $\mathrm{MeCN}$ in 10 min]: $6.020 \mathrm{~min}$. HRMS (ESI $\left.{ }^{-}\right) \mathrm{m} / z$ : calcd for $\mathrm{C}_{67} \mathrm{H}_{57} \mathrm{~N}_{7} \mathrm{O}_{23}$ 1327.35058; found 1327.35014.

Tetrapodal 18. Following the general coupling procedure, compound $17^{46,47}$ ( $25 \mathrm{mg}, 0.05 \mathrm{mmol}, 1.00$ equiv), HATU (105 $\mathrm{mg}, 0.27 \mathrm{mmol}, 4.80$ equiv), intermediate $7(130 \mathrm{mg}, 0.31 \mathrm{mmol}, 4.80$ equiv) and DIPEA ( $87 \mu \mathrm{L}, 0.58 \mathrm{mmol}, 10.00$ equiv) afforded 18 (33.2 $\mathrm{mg}, 33 \%)$ as an amorphous white solid. ${ }^{1} \mathrm{H}$ NMR $\left(400 \mathrm{MHz}, \mathrm{CDCl}_{3}\right)$ 
$\delta: 9.10\left(\mathrm{~d}, J=2.4 \mathrm{~Hz}, 4 \mathrm{H}, \mathrm{NH}-1^{i} \operatorname{Trp}\right), 8.25(\mathrm{t}, J=1.7 \mathrm{~Hz}, 4 \mathrm{H}, \mathrm{Ar})$, $7.98(\mathrm{dt}, J=7.8,1.4 \mathrm{~Hz}, 4 \mathrm{H}, \mathrm{Ar}), 7.77(\mathrm{dt}, J=7.8,1.4 \mathrm{~Hz}, 4 \mathrm{H}, \mathrm{Ar})$, $7.48(\mathrm{~m}, 8 \mathrm{H}, \mathrm{Ar}), 7.14(\mathrm{~m}, 8 \mathrm{H}, \mathrm{Ar}), 6.93(\mathrm{~d}, J=2.3 \mathrm{~Hz}, 4 \mathrm{H}, \mathrm{Ar}), 6.67$ (d, $J=7.8 \mathrm{~Hz}, 4 \mathrm{H}, \mathrm{NHCO}), 4.84(\mathrm{~m}, 4 \mathrm{H}, \alpha$-CHTrp), $3.86(\mathrm{~s}, 12 \mathrm{H}$, $\left.\mathrm{OCH}_{3}\right), 3.60\left(\mathrm{~s}, 12 \mathrm{H}, \mathrm{OCH}_{3}\right), 3.24\left(\mathrm{~m}, 16 \mathrm{H}, \mathrm{OCH}_{2}\right), 3.03(\mathrm{~d}, J=9.3$ $\left.\mathrm{Hz}, 4 \mathrm{H}, \beta-\mathrm{CH}_{2} \operatorname{Trp}\right), 2.86\left(\mathrm{~d}, J=9.3 \mathrm{~Hz}, 4 \mathrm{H}, \beta-\mathrm{CH}_{2} \mathrm{Trp}\right), 2.20$ (ddd, $J$ $\left.=15.5,7.0,4.4 \mathrm{~Hz}, 4 \mathrm{H}, \mathrm{OCH}_{2}\right), 2.12(\mathrm{ddd}, J=15.5,7.0,4.4 \mathrm{~Hz}, 4 \mathrm{H}$, $\mathrm{OCH}_{2}$ ). HPLC [gradient: $\mathrm{H}_{2} \mathrm{O} / \mathrm{MeCN}, 40-100 \%$ of $\mathrm{MeCN}$ in 10 $\min ]: 7.800 \mathrm{~min}$.

Tetrapodal 19. Following the general coupling procedure, compound $17^{46,47}$ ( $23 \mathrm{mg}, 0.05 \mathrm{mmol}, 1.00$ equiv), HATU ( $99 \mathrm{mg}$, $0.26 \mathrm{mmol}, 4.80$ equiv), intermediate $8(122 \mathrm{mg}, 0.26 \mathrm{mmol}, 4.80$ equiv), and DIPEA ( $89 \mu \mathrm{L}, 0.54 \mathrm{mmol}, 10.00$ equiv) afforded 19 (56 $\mathrm{mg}, 59 \%)$ as an amorphous white solid. ${ }^{1} \mathrm{H}$ NMR $\left(300 \mathrm{MHz}, \mathrm{CDCl}_{3}\right)$ $\delta: 9.39\left(\mathrm{~m}, \mathrm{NH}^{1}-\mathrm{Trp}\right), 8.19(\mathrm{~m}, 8 \mathrm{H}, \mathrm{Ar}), 7.76(\mathrm{~d}, J=7.2 \mathrm{~Hz}, 8 \mathrm{H}, \mathrm{Ar})$, $7.57(\mathrm{dt}, J=7.3,1.7 \mathrm{~Hz}, 4 \mathrm{H}, \mathrm{Ar}), 7.22(\mathrm{~m}, 4 \mathrm{H}, \mathrm{Ar}), 7.06(\mathrm{~d}, J=2.2$ $\mathrm{Hz}, 4 \mathrm{H}, \mathrm{Ar}), 6.84$ (m, 4H, Ar), 4.93 (m, 4H, $\alpha$-CHTrp), $4.00(\mathrm{~s}, 12 \mathrm{H}$, $\left.\mathrm{OCH}_{3}\right), 3.71\left(\mathrm{~s}, 12 \mathrm{H}, \mathrm{OCH}_{3}\right), 3.34\left(\mathrm{~m}, 16 \mathrm{H}, \mathrm{OCH}_{2}\right.$ and $\left.\beta-\mathrm{CH}_{2} \mathrm{Trp}\right)$, $3.14\left(\mathrm{~d}, J=9.2 \mathrm{~Hz}, 4 \mathrm{H}, \mathrm{OCH}_{2}\right), 2.94\left(\mathrm{~d}, J=9.3 \mathrm{~Hz}, 4 \mathrm{H}, \mathrm{OCH}_{2}\right), 2.24$ (m, $8 \mathrm{H}, \mathrm{CH}_{2}$ ). HPLC [gradient: $\mathrm{H}_{2} \mathrm{O} / \mathrm{MeCN}, 70-100 \%$ of $\mathrm{MeCN}$ in $10 \mathrm{~min}$ ]: $7.208 \mathrm{~min}$.

Tetrapodal 20. Following the general coupling procedure, compound $17^{46,47}$ (26 mg, $0.06 \mathrm{mmol}, 1.00$ equiv), HATU (116 $\mathrm{mg}, 0.31 \mathrm{mmol}, 4.80$ equiv), intermediate $9(160 \mathrm{mg}, 0.31 \mathrm{mmol}, 4.80$ equiv), and DIPEA ( $130 \mu \mathrm{L}, 0.76 \mathrm{mmol}, 12.00$ equiv) afforded 20 (68 $\mathrm{mg}, 54 \%)$ as an amorphous white solid. ${ }^{1} \mathrm{H}$ NMR $\left(300 \mathrm{MHz}, \mathrm{CDCl}_{3}\right)$ $\delta: 9.26\left(\mathrm{~d}, J=2.5 \mathrm{~Hz}, 4 \mathrm{H}, \mathrm{NH}^{1}-\mathrm{Trp}\right), 8.60(\mathrm{t}, J=1.6 \mathrm{~Hz}, 4 \mathrm{H}, \mathrm{Ar})$, 8.42 (d, $J=1.6 \mathrm{~Hz}, 8 \mathrm{H}, \mathrm{Ar}$ ), 7.49 (dd, $J=6.3,2.8 \mathrm{~Hz}, 4 \mathrm{H}, \mathrm{Ar}$ ), 7.177.09 (m, 8H, Ar), 6.95 (d, $J=2.4 \mathrm{~Hz}, 4 \mathrm{H}, \mathrm{NHCO}), 6.79$ (d, $J=7.9$ $\mathrm{Hz}, 4 \mathrm{H}, \mathrm{Ar}), 4.81(\mathrm{~m}, 4 \mathrm{H}, \alpha-\mathrm{CHTrp}), 3.90\left(\mathrm{~s}, 24 \mathrm{H}, \mathrm{OCH}_{3}\right), 3.60(\mathrm{~s}$, $\left.12 \mathrm{H}, \mathrm{OCH}_{3}\right), 3.28\left(\mathrm{~m}, 16 \mathrm{H}, \mathrm{OCH}_{2}\right.$ and $\left.\beta-\mathrm{CH}_{2} \mathrm{Trp}\right), 3.08(\mathrm{~d}, J=9.3$ $\left.\mathrm{Hz}, 4 \mathrm{H}, \mathrm{OCH}_{2}\right), 2.93\left(\mathrm{~d}, J=9.3 \mathrm{~Hz}, 4 \mathrm{H}, \mathrm{OCH}_{2}\right), 2.33-2.13(\mathrm{~m}, 8 \mathrm{H}$, $\mathrm{CH}_{2}$ ). HPLC [gradient: $\mathrm{H}_{2} \mathrm{O} / \mathrm{MeCN}, 10-100 \%$ of $\mathrm{MeCN}$ in 10 $\min$ ]: $8.658 \mathrm{~min}$.

Tetrapodal 21. Following the general procedure for methyl ester deprotection, intermediate $18(33 \mathrm{mg}, 0.02 \mathrm{mmol})$ and $\mathrm{LiOH} \cdot \mathrm{H}_{2} \mathrm{O}$ (13 mg, $0.3 \mathrm{mmol}, 16.00$ equiv) afforded $21(21 \mathrm{mg}$, quant) as an amorphous white solid. ${ }^{1} \mathrm{H}$ NMR $\left(500 \mathrm{MHz}, \mathrm{DMSO}-d_{6}\right) \delta: 10.83(\mathrm{~d}$, $\left.J=2.6 \mathrm{~Hz}, 4 \mathrm{H}, \mathrm{NH}-1^{i} \operatorname{Trp}\right), 8.18$ (d, $\left.J=7.7 \mathrm{~Hz}, 4 \mathrm{H}, \mathrm{NHCO}\right) 8.14$ (m, $4 \mathrm{H}, \mathrm{Ar}), 7.96(\mathrm{dt}, J=7.7,1.5 \mathrm{~Hz}, 4 \mathrm{H}, \mathrm{Ar}), 7.83(\mathrm{dt}, J=7.7,1.5 \mathrm{~Hz}$, $4 \mathrm{H}, \mathrm{NHCO}), 7.61(\mathrm{t}, J=7.7 \mathrm{~Hz}, 4 \mathrm{H}, \mathrm{Ar}), 7.56(\mathrm{dd}, J=6.3,2.7 \mathrm{~Hz}$, $4 \mathrm{H}, \mathrm{Ar}), 7.15(\mathrm{~d}, J=2.6 \mathrm{~Hz}, 4 \mathrm{H}, \mathrm{Ar}), 7.10(\mathrm{~m}, 7 \mathrm{H}, \mathrm{Ar}), 4.54(\mathrm{~m}, 4 \mathrm{H}$, $\alpha$-CHTrp), $3.38\left(\mathrm{~m}, 12 \mathrm{H}, \mathrm{CH}_{2}\right.$ ), $3.16\left(\mathrm{~m}, 4 \mathrm{H}, \beta-\mathrm{CH}_{2}\right.$ Trp), 3.05 (m, $\left.4 \mathrm{H}, \beta-\mathrm{CH}_{2} \mathrm{Trp}\right), 2.29\left(\mathrm{~m}, 12 \mathrm{H}, \mathrm{CH}_{2}\right) .{ }^{13} \mathrm{C}$ NMR $(126 \mathrm{MHz}$, DMSO$\left.d_{6}\right) \delta: 173.4,170.3,167.4,139.1,133.2,132.6,131.4,129.2,129.1$, $128.3,128.0,124.6,124.3,121.3,119.2,118.1,110.5,68.8,67.1,53.0$, 44.9, 35.8, 27.3. HPLC [gradient: $\mathrm{H}_{2} \mathrm{O} / \mathrm{MeCN}, 10-100 \%$ of $\mathrm{MeCN}$ in $10 \mathrm{~min}$ ]: $7.435 \mathrm{~min}$. HRMS $\left(\mathrm{ESI}^{-}\right) \mathrm{m} / z$ : calcd for $\mathrm{C}_{89} \mathrm{H}_{84} \mathrm{~N}_{8} \mathrm{O}_{24}$ 1648.55985; found 1648.55573 .

Tetrapodal 22. Following the general procedure for methyl ester deprotection, intermediate 19 (56 mg, $0.03 \mathrm{mmol}, 1.00$ equiv) and $\mathrm{LiOH} \cdot \mathrm{H}_{2} \mathrm{O}(21 \mathrm{mg}, 0.050 \mathrm{mmol}, 16.00$ equiv) afforded $22(36 \mathrm{mg}$, $70 \%)$ as an amorphous white solid. ${ }^{1} \mathrm{H}$ NMR $\left(400 \mathrm{MHz}\right.$, DMSO- $\left.d_{6}\right)$ $\delta: 10.82$ (bs, $\left.4 \mathrm{H}, \mathrm{NH}-1^{i} \operatorname{Trp}\right), 8.16(\mathrm{~d}, J=7.7 \mathrm{~Hz}, 4 \mathrm{H}), 8.06$ (d, $J=8.0$ $\mathrm{Hz}, 8 \mathrm{H}, \mathrm{Ar}), 7.73(\mathrm{~d}, J=8.0 \mathrm{~Hz}, 8 \mathrm{H}, \mathrm{Ar}), 7.58(\mathrm{~d}, J=7.7 \mathrm{~Hz}, 4 \mathrm{H}$, $\mathrm{NHCO}), 7.18-7.13(\mathrm{~m}, 8 \mathrm{H}, \mathrm{Ar}), 7.10(\mathrm{t}, J=7.5 \mathrm{~Hz}, 3 \mathrm{H}, \mathrm{Ar}), 4.54$ (m, 4H, $\alpha$-CHTrp), 3.47-3.35 (m, $12 \mathrm{H}, \mathrm{OCH}_{2}$ and $\beta$ - $\mathrm{CH}_{2} \mathrm{Trp}$ ), 3.12 $\left(\mathrm{m}, 6 \mathrm{H}, \mathrm{OCH}_{2}\right), 3.05\left(\mathrm{~m}, 4 \mathrm{H}, \beta-\mathrm{CH}_{2} \mathrm{Trp}\right), 2.30$ (tq, $J=14.5,7.5,7.0$ $\left.\mathrm{Hz}, 8 \mathrm{H}, \mathrm{CH}_{2}\right) .{ }^{13} \mathrm{C}$ NMR (101 MHz, DMSO-d 6 ) $\delta: 173.3,170.2$, 167.2 , 143.2, 133.1, 129.9, 129.3, 128.3, 124.6, 124.1, 121.4, 119.1, $118.5,110.5,68.8,67.7,67.1,64.9,52.9,44.9,35.7,30.5,27.2,19.1$. HPLC [gradient: $\mathrm{H}_{2} \mathrm{O} / \mathrm{MeCN}, 10-100 \%$ of $\mathrm{MeCN}$ in $10 \mathrm{~min}$ ]: 7.110 min. HRMS $\left(\right.$ ESI $\left.^{-}\right) \mathrm{m} / z$ : calcd for $\mathrm{C}_{89} \mathrm{H}_{84} \mathrm{~N}_{8} \mathrm{O}_{24}$ 1648.55985; found 1648.56095 .

Tetrapodal 23. Following the general procedure for methyl ester deprotection, intermediate 20 (46 mg, $0.03 \mathrm{mmol}, 1.00$ equiv) and $\mathrm{LiOH} \cdot \mathrm{H}_{2} \mathrm{O}(30 \mathrm{mg}, 0.72 \mathrm{mmol}, 24.00$ equiv) afforded $23(42 \mathrm{mg}$, quant.) as an amorphous white solid. ${ }^{1} \mathrm{H}$ NMR (400 MHz, DMSO$\left.d_{6}\right) \delta: 10.92\left(\mathrm{bs}, 4 \mathrm{H}, \mathrm{NH}-1^{i} \mathrm{Trp}\right), 8.48(\mathrm{t}, J=1.6 \mathrm{~Hz}, 4 \mathrm{H}, \mathrm{Ar}), 8.32$ (d, $J=1.6 \mathrm{~Hz}, 8 \mathrm{H}, \mathrm{Ar}), 8.19$ (d, $J=7.7 \mathrm{~Hz}, 4 \mathrm{H}, \mathrm{NHCO}), 7.60$ (dd, $J=$
7.0, $2.0 \mathrm{~Hz}, 4 \mathrm{H}, \mathrm{Ar}$ ), 7.17 (d, J = 2.4 Hz, 4H, Ar), 7.16-7.09 (m, 8H, $\mathrm{Ar}$ ), 4.54 (m, $4 \mathrm{H}, \alpha$-CHTrp), $3.45\left(\mathrm{~m}, 8 \mathrm{H}, \mathrm{OCH}_{2}\right), 3.23-3.15$ (m, $12 \mathrm{H}, \mathrm{OCH}_{2}$ and $\beta-\mathrm{CH}_{2} \mathrm{Trp}$ ), 3.11-3.03 (m, $\left.4 \mathrm{H}, \beta-\mathrm{CH}_{2} \mathrm{Trp}\right), 2.40-$ $2.24\left(\mathrm{~m}, 8 \mathrm{H}, \mathrm{CH}_{2}\right) .{ }^{13} \mathrm{C}$ NMR $\left(100 \mathrm{MHz}, \mathrm{DMSO}-d_{6}\right) \delta: 173.3,170.3$, $166.6,139.6,133.2,132.9,132.0,128.5,128.4,124.7,123.5,121.4$, $119.2,118.5,110.6,68.8,67.1,52.9,44.9,35.7,27.3$. HPLC [gradient: $\mathrm{H}_{2} \mathrm{O} / \mathrm{MeCN}, 10-100 \%$ of $\mathrm{MeCN}$ in $10 \mathrm{~min}$ ]: $6.198 \mathrm{~min}$. HRMS $\left(\mathrm{ESI}^{-}\right) \mathrm{m} / z$ : calcd for $\mathrm{C}_{93} \mathrm{H}_{84} \mathrm{~N}_{8} \mathrm{O}_{32}$ 1824.51916; found 1824.52142 .

Dimethyl 4,4'-(3-(2-((tert-Butoxycarbonyl)amino)-3-methoxy-3oxopropyl)-1H-indole-2,7-diyl)dibenzoate (24). Commercially available $N$-Boc-L-tryptophan methyl ester $1(100 \mathrm{mg}, 0.31 \mathrm{mmol}, 1.00$ equiv) was treated with bis(pinacolato)diboron (199 mg, $0.8 \mathrm{mmol}$, 1.25 equiv), (1,5-cyclooctadiene) (methoxy)iridium(I) dimer ([Ir$\left.(\operatorname{cod}) \mathrm{OMe}_{2}\right)(5 \mathrm{mg}, 0.008 \mathrm{mmol}, 2.5 \mathrm{~mol} \%)$, and 4,4'-di-tert-butyl2,2'-bipyridine (dtbpy) ( $4 \mathrm{mg}, 0.016 \mathrm{mmol}, 5 \mathrm{~mol} \%)$ as mentioned above for 3 . The resulting brown residue (intermediate 2) was treated with tris(dibenzylideneacetone)dipalladium $\left(\mathrm{Pd}_{2}(\mathrm{dba})_{3}\right)(14 \mathrm{mg}$, $0.014 \mathrm{mmol}, 5 \mathrm{~mol} \%)$, SPhos (12 $\mathrm{mg}, 0.030 \mathrm{mmol}, 10 \mathrm{~mol} \%$ ), tribasic potassium phosphate $(253 \mathrm{mg}, 1.20 \mathrm{mmol}, 4.00$ equiv $)$, and methyl 4-bromobenzoate ( $141 \mathrm{mg}, 0.66 \mathrm{mmol}, 2.20$ equiv). The tube was sealed and placed under an argon atmosphere. Then, anhydrous toluene $(3 \mathrm{~mL})$ was added via a syringe. The reaction mixture was stirred at $80{ }^{\circ} \mathrm{C}$ for $12 \mathrm{~h}$ and worked up as described in the general $\mathrm{C} 7$ arylation procedure. The resulting brown residue was purified by CCTLC using dichloromethane/methanol $(20: 1)$ as the eluent to afford compound $24(50 \mathrm{mg}, 30 \%)$ as a brown amorphous solid. ${ }^{1} \mathrm{H}$ NMR $\left(400 \mathrm{MHz}\right.$, methanol- $\left.d_{4}\right) \delta: 7.94(\mathrm{~m}, 4 \mathrm{H}, \mathrm{Ar}), 7.54(\mathrm{~m}, 5 \mathrm{H}$, $\mathrm{Ar}), 7.04(\mathrm{~d}, J=3.9 \mathrm{~Hz}, 2 \mathrm{H}, \mathrm{Ar}), 4.69\left(\mathrm{~s}, 3 \mathrm{H}, \mathrm{OCH}_{3}\right), 4.30(\mathrm{~m}, 1 \mathrm{H}$, $\alpha$-CHTrp), $3.77\left(\mathrm{~s}, 6 \mathrm{H}, \mathrm{OCH}_{3}\right), 3.22\left(\mathrm{~m}, 1 \mathrm{H}, \beta-\mathrm{CH}_{2}\right.$ Trp), $3.18(\mathrm{~m}$, $\left.1 \mathrm{H}, \beta-\mathrm{CH}_{2} \mathrm{Trp}\right), 1.17\left(\mathrm{~s}, 9 \mathrm{H}, \mathrm{CH}_{3}\right)$. HPLC [gradient: $\mathrm{H}_{2} \mathrm{O} / \mathrm{MeCN}$, $10-100 \%$ of $\mathrm{MeCN}$ in $10 \mathrm{~min}$ ]: $10.514 \mathrm{~min}$.

Tetramethyl 5,5'-(3-(2-((tert-Butoxycarbonyl)amino)-3-methoxy-3-oxopropyl)-1H-indole-2,7-diyl)diisophthalate (25). Commercially available $\mathrm{N}$-Boc-L-tryptophan methyl ester 1 (200 mg, $0.63 \mathrm{mmol}, 1.00$ equiv) was treated with bis(pinacolato)diboron (399 $\mathrm{mg}, 1.60 \mathrm{mmol}, 2.50$ equiv), (1,5-cyclooctadiene) (methoxy)iridium(I) dimer $\left([\operatorname{Ir}(\operatorname{cod}) \mathrm{OMe}]_{2}\right)(10 \mathrm{mg}, 0.016 \mathrm{mmol}, 2.5 \mathrm{~mol} \%)$, and 4,4'-di-tert-butyl-2,2'-bipyridine (d'bpy) ( $5 \mathrm{mg}, 0.031 \mathrm{mmol}, 5 \mathrm{~mol}$ $\%$ ) as mentioned above for 3 . The brown residue (intermediate 2 ) was treated with tris(dibenzylideneacetone)dipalladium $\left(\mathrm{Pd}_{2}(\mathrm{dba})_{3}\right)$ (48 mg, $52.60 \mu \mathrm{mol}, 5 \mathrm{~mol} \%$ ), SPhos (43 mg, $105.20 \mu \mathrm{mol}, 10 \mathrm{~mol}$ $\%)$, tribasic potassium phosphate ( $893 \mathrm{mg}, 4.20 \mathrm{mmol}$, 4.00 equiv), and dimethyl 5-bromoisophthalate $(632 \mathrm{mg}, 2.31 \mathrm{mmol}, 2.20$ equiv) as described above for $\mathbf{2 4}$ to give $\mathbf{2 5}$ (190 $\mathrm{mg}, \mathbf{4 3 \%}$ ) as a brown amorphous solid. ${ }^{1} \mathrm{H}$ NMR (400 MHz, DMSO- $\left.d_{6}\right) \delta: 11.32$ (bs, $1 \mathrm{H}$, $\left.\mathrm{NH}-1^{i} \operatorname{Trp}\right), 8.50(\mathrm{dt}, J=11.5,1.7 \mathrm{~Hz}, 2 \mathrm{H}, \mathrm{Ar}), 8.40(\mathrm{~d}, J=1.7 \mathrm{~Hz}$, $2 \mathrm{H}, \mathrm{Ar}), 8.33$ (d, $J=1.7 \mathrm{~Hz}, 2 \mathrm{H}, \mathrm{Ar}), 7.72(\mathrm{~m}, 1 \mathrm{H}, \mathrm{Ar}), 7.22(\mathrm{~m}, 2 \mathrm{H}$, $\mathrm{Ar}), 7.14(\mathrm{~d}, J=8.1 \mathrm{~Hz}, 1 \mathrm{H}, \mathrm{NHCO}), 4.22(\mathrm{~m}, 1 \mathrm{H}, \alpha$-CHTrp), 3.93 $\left(\mathrm{m}, 12 \mathrm{H}, \mathrm{OCH}_{3}\right), 3.43\left(\mathrm{~s}, 3 \mathrm{H} \mathrm{OCH}{ }_{3}\right), 3.35\left(\mathrm{~m}, 1 \mathrm{H}, \beta-\mathrm{CH}_{2}\right.$ Trp $), 3.21$ $\left(\mathrm{m}, 1 \mathrm{H}, \beta-\mathrm{CH}_{2} \mathrm{Trp}\right), 1.24\left(\mathrm{~s}, 9 \mathrm{H}, \mathrm{CH}_{3}\right)$. HPLC [gradient: $\mathrm{H}_{2} \mathrm{O} /$ $\mathrm{MeCN}, 20-100 \%$ of $\mathrm{MeCN}$ in $10 \mathrm{~min}$ ]: $11.380 \mathrm{~min}$.

3-(2,7-Bis(4-(methoxycarbonyl)phenyl)-1H-indol-3-yl)-1-methoxy-1-oxopropan-2-aminium 2,2,2-Trifluoro-acetate (26). A cold $\left(0{ }^{\circ} \mathrm{C}\right)$ solution of compound $24(50 \mathrm{mg}, 0.09 \mathrm{mmol})$ in dichloromethane $(5 \mathrm{~mL})$ was treated with TFA $(0.25 \mathrm{~mL})$ as described for 7 to afford 26 (47 mg, 91\%) in the salt form. ${ }^{1} \mathrm{H}$ NMR $\left(300 \mathrm{MHz}, \mathrm{CDCl}_{3}\right) \delta: 8.61\left(\mathrm{~m}, 1 \mathrm{H}, \mathrm{NH}-1^{i} \mathrm{Trp}\right), 8.13(\mathrm{~d}, J=7.9 \mathrm{~Hz}$, $2 \mathrm{H}, \mathrm{Ar}), 8.02(\mathrm{~d}, J=7.7 \mathrm{~Hz}, 2 \mathrm{H}, \mathrm{Ar}), 7.68(\mathrm{~d}, J=7.9 \mathrm{~Hz}, 3 \mathrm{H}, \mathrm{Ar})$, $7.54(\mathrm{~d}, J=7.7 \mathrm{~Hz}, 2 \mathrm{H}, \mathrm{Ar}), 7.19(\mathrm{~m}, 2 \mathrm{H}, \mathrm{Ar}), 4.19(\mathrm{~m}, 1 \mathrm{H}, \alpha-$ CHTrp), $3.92\left(\mathrm{~s}, 3 \mathrm{H}, \mathrm{OCH}_{3}\right), 3.85\left(\mathrm{~s}, 3 \mathrm{H}, \mathrm{OCH}_{3}\right), 3.64(\mathrm{~s}, 2 \mathrm{H}, \beta$ $\mathrm{CH}_{2} \mathrm{Trp}$ ), 3.35 (s, $3 \mathrm{H}, \mathrm{OCH}_{3}$ ). HPLC [gradient: $\mathrm{H}_{2} \mathrm{O} / \mathrm{MeCN}, 10-$ $100 \%$ of $\mathrm{MeCN}$ in $10 \mathrm{~min}$ ]: $7.452 \mathrm{~min}$.

3-(2,7-Bis(3,5-bis(methoxycarbonyl)phenyl)-1H-indol-3-yl)-1methoxy-1-oxopropan-2-aminium 2,2,2-Trifluoroacetate (27). A cold $\left(0{ }^{\circ} \mathrm{C}\right)$ solution of compound $25(170 \mathrm{mg}, 0.24 \mathrm{mmol})$ in dichloromethane $(15 \mathrm{~mL})$ was treated with TFA $(0.7 \mathrm{~mL})$ as described for 7 to afford 27 (173 mg, quant.) in the salt form. ${ }^{1} \mathrm{H}$ NMR $\left(400 \mathrm{MHz}\right.$, DMSO- $\left.d_{6}\right) \delta: 11.32\left(\mathrm{~s}, 1 \mathrm{H}, \mathrm{NH}-1^{i} \mathrm{Trp}\right), 8.50(\mathrm{dt}, J$ $=11.5,1.7 \mathrm{~Hz}, 2 \mathrm{H}, \mathrm{Ar}), 8.40(\mathrm{~d}, J=1.7 \mathrm{~Hz}, 2 \mathrm{H}, \mathrm{Ar}), 8.33(\mathrm{~d}, J=1.7$ $\mathrm{Hz}, 2 \mathrm{H}, \mathrm{Ar}$ ), 7.72 (m, 1H, Ar), 7.22 (d, J = 4.6 Hz, 2H, Ar), 7.14 (d, J 
$=8.1 \mathrm{~Hz}, 1 \mathrm{H}, \mathrm{NHCO}), 4.22(\mathrm{~m}, 1 \mathrm{H}, \alpha$-CHTrp $), 3.93(\mathrm{~s}, 12 \mathrm{H}$, $\left.\mathrm{OCH}_{3}\right), 3.44\left(\mathrm{~s}, 3 \mathrm{H}, \mathrm{OCH}_{3}\right), 3.31\left(\mathrm{~m}, 1 \mathrm{H}, \beta-\mathrm{CH}_{2} \mathrm{Trp}\right), 3.22(\mathrm{~m}, 1 \mathrm{H}$, $\beta-\mathrm{CH}_{2}$ Trp). HPLC [gradient: $\mathrm{H}_{2} \mathrm{O} / \mathrm{MeCN}, 20-100 \%$ of $\mathrm{MeCN}$ in $10 \mathrm{~min}$ ]: $7.698 \mathrm{~min}$.

Tripodal 28. Following the general coupling procedure, a solution of the tripodal polyacid $10^{45}$ ( $5 \mathrm{mg}, 0.02 \mathrm{mmol}, 1.00$ equiv), HATU (27 mg, $0.07 \mathrm{mmol}, 3.60$ equiv), and intermediate 27 (50 mg, 0.07 mmol, 3.60 equiv) in dry DMF $(20 \mathrm{~mL})$ was treated with DIPEA ( $0.025 \mathrm{~mL}, 0.15 \mathrm{mmol}, 8.00$ equiv) to afford compound $28(36 \mathrm{mg}$, $88 \%)$ as an amorphous white solid. ${ }^{1} \mathrm{H}$ NMR $\left(400 \mathrm{MHz} \mathrm{CDCl}_{3}\right) \delta$ : 8.57 (s, 6H, Ar), 8.52-8.49 (m, 8H, Ar), 8.47 (s, 3H, Ar), 7.62 (d, J = $7.8 \mathrm{~Hz}, 3 \mathrm{H}, \mathrm{Ar}), 7.26(\mathrm{~m}, 7 \mathrm{H}, \mathrm{Ar}), 6.25(\mathrm{~m}, 3 \mathrm{H}, \mathrm{NHCO}), 4.86(\mathrm{~m}$, $3 \mathrm{H}, \alpha$-CHTrp), $3.67-3.56\left(\mathrm{~m}, 45 \mathrm{H}, \mathrm{OCH}_{3}\right), 3.52\left(\mathrm{~m}, 6, \beta-\mathrm{CH}_{2} \operatorname{Trp}\right)$, $1.44\left(\mathrm{~m}, 12 \mathrm{H}, \mathrm{OCH}_{2}\right)$. HPLC [gradient: $\mathrm{H}_{2} \mathrm{O} / \mathrm{MeCN}, 20-100 \%$ of $\mathrm{MeCN}$ in $10 \mathrm{~min}$ ]: $6.393 \mathrm{~min}$.

Tetrapodal 29. Following the general coupling procedure, compound $17^{46,47}(7 \mathrm{mg}, 0.02 \mathrm{mmol}, 1.00$ equiv), HATU (30 mg, $0.08 \mathrm{mmol}, 4.80$ equiv), intermediate 26 ( $47 \mathrm{mg}, 0.08 \mathrm{mmol}, 4.80$ equiv), and DIPEA (0.026 mL, $0.16 \mathrm{mmol}, 10.00$ equiv) afforded compound $29(15 \mathrm{mg}, 40 \%)$ as an amorphous white solid. ${ }^{1} \mathrm{H}$ NMR $\left(400 \mathrm{MHz}, \mathrm{CDCl}_{3}\right) \delta: 8.72\left(\mathrm{~s}, 4 \mathrm{H}, \mathrm{NH}^{1}-\mathrm{Trp}\right), 8.11(\mathrm{~d}, J=8.0 \mathrm{~Hz}$, $8 \mathrm{H}, \mathrm{Ar}$ ), 8.03 (d, $J=8.0 \mathrm{~Hz}, 8 \mathrm{H}, \mathrm{Ar}), 7.68(\mathrm{~d}, J=8.0 \mathrm{~Hz}, 8 \mathrm{H}, \mathrm{Ar})$, $7.60(\mathrm{~d}, J=8.0 \mathrm{~Hz}, 12 \mathrm{H}, \mathrm{Ar}), 7.22-7.11(\mathrm{~m}, 8 \mathrm{H}, \mathrm{Ar}), 6.61(\mathrm{~d}, J=7.9$ $\mathrm{Hz}, 4 \mathrm{H}, \mathrm{NHCO}), 4.82\left(\mathrm{~m}, 4 \mathrm{H}, \alpha\right.$-CHTrp), $3.91\left(\mathrm{~s}, 12 \mathrm{H}, \mathrm{OCH}_{3}\right)$, $3.87\left(\mathrm{~s}, 12 \mathrm{H}, \mathrm{OCH}_{3}\right), 3.46\left(\mathrm{~m}, 8 \mathrm{H}, \beta-\mathrm{CH}_{2} \mathrm{Trp}\right), 3.28(\mathrm{~s}, 12 \mathrm{H}$, $\left.\mathrm{OCH}_{3}\right), 3.21\left(\mathrm{dd}, J=10.1,5.4 \mathrm{~Hz}, 6 \mathrm{H}, \mathrm{OCH}_{2}\right), 3.11-2.97(\mathrm{~m}, 8 \mathrm{H}$, $\left.\mathrm{OCH}_{2}\right), 2.06\left(\mathrm{~m}, 10 \mathrm{H}, \mathrm{OCH}_{2}\right)$. HPLC [gradient: $\mathrm{H}_{2} \mathrm{O} / \mathrm{MeCN}, 50-$ $100 \%$ of $\mathrm{MeCN}$ in $10 \mathrm{~min}$ ]: $7.208 \mathrm{~min}$.

Tetrapodal 30. Following the general coupling procedure, compound $17^{46,47}$ (6 mg, $0.01 \mathrm{mmol}, 1.00$ equiv), HATU $(27 \mathrm{mg}$, $0.07 \mathrm{mmol}, 4.80$ equiv), intermediate $27(50 \mathrm{mg}, 0.07 \mathrm{mmol}, 4.80$ equiv), and DIPEA (0.024 mL, $0.14 \mathrm{mmol}, 10.00$ equiv) afforded compound 30 (22 mg, 54\%) as an amorphous solid. ${ }^{1} \mathrm{H}$ NMR (400 $\mathrm{MHz}, \mathrm{CDCl}_{3}$ ) $\delta: 9.35$ (s, 4H, NH ${ }^{1}-\mathrm{Trp}$ ), 8.53 (s, 4H, Ar), 8.48 (s, $4 \mathrm{H}, \mathrm{Ar}), 8.40$ (s, 8H, Ar), 8.30 (s, 8H, Ar), 7.64 (m, 4H, Ar), 7.14 (m, $8 \mathrm{H}, \mathrm{Ar}), 6.74(\mathrm{~d}, J=8.0 \mathrm{~Hz}, 4 \mathrm{H}, \mathrm{NHCO}), 4.82(\mathrm{~m}, 4 \mathrm{H}, \alpha$-CHTrp), $3.83\left(\mathrm{~s}, 48 \mathrm{H}, \mathrm{OCH}_{3}\right), 3.38\left(\mathrm{~m}, 16 \mathrm{H}, \beta-\mathrm{CH}_{2} \mathrm{Trp}\right.$ and $\left.\mathrm{OCH}_{2}\right), 3.26(\mathrm{~s}$, $\left.12 \mathrm{H}, \mathrm{OCH}_{3}\right), 3.09\left(\mathrm{~m}, 8 \mathrm{H}, \mathrm{OCH}_{2}\right), 2.16\left(\mathrm{~m}, 8 \mathrm{H}, \mathrm{CH}_{2}\right) . \mathrm{HPLC}$ [gradient: $\mathrm{H}_{2} \mathrm{O} / \mathrm{MeCN}, 50-100 \%$ of $\mathrm{MeCN}$ in $10 \mathrm{~min}$ ]: $11.996 \mathrm{~min}$.

Tripodal 31. Following the general procedure for methyl ester deprotection, intermediate $28(30 \mathrm{mg}, 0.01 \mathrm{mmol}, 1.00$ equiv) and $\mathrm{LiOH} \cdot \mathrm{H}_{2} \mathrm{O}$ (19 mg, $0.44 \mathrm{mmol}, 30$ equiv) afforded 31 (24 mg, 89\%) as an amorphous white solid. ${ }^{1} \mathrm{H}$ NMR $\left(400 \mathrm{MHz}\right.$, DMSO- $\left.d_{6}\right) \delta$ : 11.24 (s, 3H, NH-1 ${ }^{i} \mathrm{Trp}$ ), 8.47 (dt, $\left.J=6.9,1.6 \mathrm{~Hz}, 4 \mathrm{H}, \mathrm{Ar}\right), 8.36$ (d, $J$ $=7.9 \mathrm{~Hz}, 3 \mathrm{H}, \mathrm{NHCO}), 8.31(\mathrm{dd}, J=8.3,1.6 \mathrm{~Hz}, 12 \mathrm{H}, \mathrm{Ar}), 7.74(\mathrm{dd}, J$ $=7.2,1.9 \mathrm{~Hz}, 3 \mathrm{H}, \mathrm{Ar}), 7.17$ (d, $J=7.5 \mathrm{~Hz}, 6 \mathrm{H}, \mathrm{Ar}), 4.50(\mathrm{~m}, 3 \mathrm{H}, \alpha-$ CHTrp), 3.29 (m, 3H, $\beta-\mathrm{CH}_{2}$ Trp), 3.18 (m, 3H, $\beta-\mathrm{CH}_{2} \operatorname{Trp}$ ), 1.97 (s, $\left.12 \mathrm{H}, \mathrm{CH}_{2}\right) .{ }^{13} \mathrm{C}$ NMR $\left(126 \mathrm{MHz}\right.$, DMSO-d $\left.d_{6}\right) \delta: 172.8,170.4,166.7$, $166.5,139.6,135.4,133.9,133.5,133.4,133.4,131.7,131.4,129.4$, $128.9,128.6,123.9,122.7,119.8,119.2,109.3,93.0,52.9,30.5,29.3$, 29.2, 26.9. HPLC [gradient: $\mathrm{H}_{2} \mathrm{O} / \mathrm{MeCN}, 10-100 \%$ of $\mathrm{MeCN}$ in 10 min]: $5.972 \mathrm{~min}$. HRMS $\left(\mathrm{ESI}^{-}\right) \mathrm{m} / z$ : calcd for $\mathrm{C}_{91} \mathrm{H}_{69} \mathrm{~N}_{7} \mathrm{O}_{35}$ 1817.36781; found 1817.36886.

Tetrapodal 32. Following the general procedure for methyl ester deprotection, intermediate $29(15 \mathrm{mg}, 0.01 \mathrm{mmol}, 1.00$ equiv) and $\mathrm{LiOH} \cdot \mathrm{H}_{2} \mathrm{O}(7 \mathrm{mg}, 0.16 \mathrm{mmol}, 24.00$ equiv) afforded compound 32 (11 mg, 76\%) as an amorphous white solid. ${ }^{1} \mathrm{H}$ NMR (500 MHz, DMSO-d D $\delta: 11.02$ (bs, $4 \mathrm{H}, \mathrm{NH}-1^{i} \operatorname{Trp}$ ), 8.27 (d, $J=8.2 \mathrm{~Hz}, 4 \mathrm{H}$, NHCO), 8.04 (d, $J=8.1 \mathrm{~Hz}, 8 \mathrm{H}, \mathrm{Ar}), 7.98(\mathrm{~d}, J=8.1 \mathrm{~Hz}, 8 \mathrm{H}, \mathrm{Ar})$, 7.74 (m, 20H, Ar), 7.13 (m, 8H, Ar), 4.61 (m, 4H, $\alpha$-CHTrp), 3.33 $\left(\mathrm{m}, 20 \mathrm{H}, \mathrm{OCH}_{2}\right.$ and $\left.\beta-\mathrm{CH}_{2} \mathrm{Trp}\right), 3.14\left(\mathrm{~m}, 4 \mathrm{H}, \beta-\mathrm{CH}_{2} \mathrm{Trp}\right), 2.21(\mathrm{~m}$, $\left.8 \mathrm{H}, \mathrm{CH}_{2}\right) .{ }^{13} \mathrm{C}$ NMR (400 MHz, DMSO- $\left.d_{6}\right) \delta: 173.2,170.1,167.2$, 143.1, 136.6, 135.9, 133.5, 129.7, 129.4, 129.2, 129.1, 129.0, 128.7, $124.4,122.7,119.7,119.3,109.7,68.8,67.4,66.9,53.0,44.9,35.7$, 27.4. HPLC [gradient: $\mathrm{H}_{2} \mathrm{O} / \mathrm{MeCN}, 10-100 \%$ of $\mathrm{MeCN}$ in $10 \mathrm{~min}$ ]: 7.295 min. HRMS $\left(\mathrm{ESI}^{-}\right) \mathrm{m} / z$ : calcd for $\mathrm{C}_{117} \mathrm{H}_{98} \mathrm{~N}_{8} \mathrm{O}_{32} 2126.62871$; found 2126.62712 .

Tetrapodal 33. Following the general procedure for methyl ester deprotection, intermediate $30(20.0 \mathrm{mg}, 0.01 \mathrm{mmol}, 1.00$ equiv $)$ and $\mathrm{LiOH} \cdot \mathrm{H}_{2} \mathrm{O}$ (12 mg, $0.29 \mathrm{mmol}, 40.00$ equiv) afforded $33(17.0 \mathrm{mg}$,
95\%) as an amorphous white solid. ${ }^{1} \mathrm{H}$ NMR $\left(400 \mathrm{MHz}\right.$, DMSO- $\left.d_{6}\right)$ $\delta: 11.23$ (s, 4H, NH-1 $\left.{ }^{i} \mathrm{Trp}\right), 8.47$ (dt, $\left.J=6.3,1.6 \mathrm{~Hz}, 8 \mathrm{H}, \mathrm{Ar}\right), 8.30$ (dd, $J=13.5,1.6 \mathrm{~Hz}, 16 \mathrm{H}, \mathrm{Ar}), 8.18(\mathrm{~d}, J=7.9 \mathrm{~Hz}, 4 \mathrm{H}, \mathrm{NHCO}), 7.74$ (m, 4H, Ar), 7.15 (d, $J=6.2 \mathrm{~Hz}, 8 \mathrm{H}, \mathrm{Ar}), 4.51$ (m, $4 \mathrm{H}, \alpha$-CHTrp), $3.35\left(\mathrm{~m}, 20 \mathrm{H}, \mathrm{OCH}_{2}\right.$ and $\left.\beta-\mathrm{CH}_{2} \operatorname{Trp}\right), 3.15\left(\mathrm{~m}, 4 \mathrm{H}, \beta-\mathrm{CH}_{2} \operatorname{Trp}\right), 2.19$ $\left(\mathrm{m}, 8 \mathrm{H}, \mathrm{CH}_{2}\right) .{ }^{13} \mathrm{C}$ NMR $\left(126 \mathrm{MHz}, \mathrm{DMSO}-d_{6}\right) \delta: 172.9,170.0$, $166.7,166.7,139.5,135.6,133.8,133.4,131.8,129.4,128.9,128.6$, 123.9, 122.6, 119.7, 119.2, 109.2, 68.9, 67.1, 52.8, 44.8, 35.6, 27.0. HPLC [gradient: $\mathrm{H}_{2} \mathrm{O} / \mathrm{MeCN}, 10-100 \%$ of $\mathrm{MeCN}$ in $10 \mathrm{~min}$ ]: 5.827 min. HRMS $\left(\mathrm{ESI}^{-}\right) \mathrm{m} / z$ : calcd for $\mathrm{C}_{125} \mathrm{H}_{96} \mathrm{~N}_{8} \mathrm{O}_{48}$ 2476.5317; found 2476.5306

Hexamethyl 5,5',5"-(3-(2-((tert-Butoxycarbonyl)amino)-3-methoxy-3-oxopropyl)-1H-indole-2,5,7-triyl)triisophthalate (35). Commercially available $N$-Boc-L-tryptophan methyl ester 1 (200 mg, 0.63 mmol, 1.00 equiv), (1,5-cyclooctadiene) (methoxy)iridium(I) dimer $\left([\mathrm{Ir}(\mathrm{cod}) \mathrm{OMe}]_{2}\right)(37.5 \mathrm{mg}, 0.056 \mathrm{mmol}, 9 \mathrm{~mol} \%)$, bis(pinacolato)diboron ( $1.12 \mathrm{~g}, 4.40 \mathrm{mmol}, 7.00$ equiv), and 3,4,7,8-tetramethyl1,10-phenantroline ( $\left.\mathrm{Me}_{4} \mathrm{Phen}\right)(26.7 \mathrm{mg}, 0.11 \mathrm{mmol}, 18 \mathrm{~mol} \%)$ were sealed in a dry reaction vial (microwave reactor vessel can also be used) equipped with a magnetic stirring bar under an argon atmosphere, and anhydrous tetrahydrofuran $(5 \mathrm{~mL})$ was added. The resulting red solution was stirred at $85^{\circ} \mathrm{C}$ for $12 \mathrm{~h}$. After cooling to room temperature and removal of volatiles under reduced pressure, the subsequent brown residue (compound 34) was treated with tris(dibenzylideneacetone) dipalladium $\left(\mathrm{Pd}_{2}(\mathrm{dba})_{3}\right) \quad(30 \mathrm{mg}, 3.20$ mmol, $5 \mathrm{~mol} \%)$, SPhos $(27 \mathrm{mg}, 0.07 \mathrm{mmol}, 10 \mathrm{~mol} \%)$, tribasic potassium phosphate $(686 \mathrm{mg}, 3.20 \mathrm{mmol}, 5.00$ equiv), and methyl dimethyl 5-bromoisophthalate $(635 \mathrm{mg}, 2.36 \mathrm{mmol}, 3.60$ equiv). The tube was sealed and placed under an argon atmosphere. Then, anhydrous toluene $(4 \mathrm{~mL})$ was added via a syringe. The reaction mixture was stirred at $80{ }^{\circ} \mathrm{C}$ for $12 \mathrm{~h}$ and worked up as described in the general $\mathrm{C} 7$ arylation procedure. The resulting brown residue was purified by CCTLC using dichloromethane/methanol (20:1) as the eluent to afford compound $35(91.2,20 \%)$ as a brown amorphous solid. ${ }^{1} \mathrm{H}$ NMR (400 MHz, $\mathrm{CDCl}_{3}$ ) $\delta: 8.75$ (bs, $\left.1 \mathrm{H}, \mathrm{NH}-1^{i} \mathrm{Trp}\right), 8.67$ $(\mathrm{m}, 2 \mathrm{H}, \mathrm{Ar}), 8.60(\mathrm{bs}, 1 \mathrm{H}), 8.56(\mathrm{~d}, J=1.6 \mathrm{~Hz}, 2 \mathrm{H}, \mathrm{Ar}), 8.51$ (d, $J=$ $1.4 \mathrm{~Hz}, 2 \mathrm{H}, \mathrm{Ar}$ ), 8.39 (d, J = $1.5 \mathrm{~Hz}, 2 \mathrm{H}, \mathrm{Ar}), 7.93$ (s, $1 \mathrm{H}, \mathrm{Ar}), 7.52$ (m, 1H, Ar), $4.96(\mathrm{~m}, 1 \mathrm{H}, \mathrm{NHCO}), 4.64(\mathrm{~m}, 1 \mathrm{H}, \alpha$-CHTrp), 4.00 (s, $\left.6 \mathrm{H}, \mathrm{OCH}_{3}\right), 3.94\left(\mathrm{~m}, 12 \mathrm{H}, \mathrm{OCH}_{3}\right), 3.53\left(\mathrm{~m}, 2 \mathrm{H}, \beta-\mathrm{CH}_{2} \mathrm{Trp}\right), 3.43$ $\left(\mathrm{s}, 3 \mathrm{H}, \mathrm{OCH}_{3}\right), 1.19\left(\mathrm{~s}, 9 \mathrm{H}, \mathrm{CH}_{3}\right) .{ }^{13} \mathrm{C} \mathrm{NMR}\left(101 \mathrm{MHz}, \mathrm{CDCl}_{3}\right) \delta$ : $172.5,166.5,166.1,165.8,154.9,142.9,139.4,135.8,133.8,133.7$, $133.6,132.6,132.5,131.8,131.5,131.3,130.2,130.1,129.0,124.3$, $122.9,118.5,110.1,79.8,54.2,52.7,52.3,28.0,24.7$. HPLC [gradient: $\mathrm{MeCN} / \mathrm{H}_{2} \mathrm{O}, 50-100 \%$ of $\mathrm{MeCN}$ in $10 \mathrm{~min}$ ]: $8.250 \mathrm{~min}$. HRMS $\left(\mathrm{ESI}^{+}\right) \mathrm{m} / z$ : calcd for $\mathrm{C}_{47} \mathrm{H}_{46} \mathrm{~N}_{2} \mathrm{O}_{16}$ 894.2847; found 894.2837.

5, 5', $5^{\prime \prime}$-(3-(2-Amino-2-carboxyethyl)- $1 \mathrm{H}$-indole-2,5,7-triyl)triisophthalic Acid (37). A cold $\left(0{ }^{\circ} \mathrm{C}\right)$ solution of compound 35 (30 $\mathrm{mg}, 0.03 \mathrm{mmol})$ in dichloromethane $(10 \mathrm{~mL})$ was treated with TFA $(0.5 \mathrm{~mL})$ as described for 7 to afford intermediate 36 in the salt form that was used in the next step without purification. Compound 36 was treated with $\mathrm{LiOH} \cdot \mathrm{H}_{2} \mathrm{O}(19.7 \mathrm{mg}, 0.47 \mathrm{mmol}, 14$ equiv $)$ following the general procedure for methyl ester deprotection to afford compound $37(18.7 \mathrm{mg}, 76 \%)$ as an amorphous white solid. ${ }^{1} \mathrm{H}$ NMR $(500 \mathrm{MHz}$, DMSO- $\left.d_{6}\right) \delta: 11.51\left(\mathrm{~s}, 1 \mathrm{H}, \mathrm{NH}-1^{i} \operatorname{Trp}\right), 8.52(\mathrm{t}, J=1.7 \mathrm{~Hz}, 1 \mathrm{H}, \mathrm{Ar})$, $8.49(\mathrm{~d}, J=1.6 \mathrm{~Hz}, 2 \mathrm{H}, \mathrm{Ar}), 8.48(\mathrm{q}, J=1.9 \mathrm{~Hz}, 1 \mathrm{H}, \mathrm{Ar}), 8.42(\mathrm{~d}, J=$ $1.6 \mathrm{~Hz}, 1 \mathrm{H}, \mathrm{Ar}), 8.40$ (d, $J=1.7 \mathrm{~Hz}, 2 \mathrm{H}, \mathrm{Ar}), 8.31(\mathrm{~d}, J=1.7 \mathrm{~Hz}, 2 \mathrm{H}$, Ar), 8.14-8.09 (m, $1 \mathrm{H}, \mathrm{Ar}), 7.49$ (d, $J=1.5 \mathrm{~Hz}, 1 \mathrm{H}, \mathrm{Ar}), 3.81-3.71$ (m, $1 \mathrm{H}, \alpha$-CHTrp), 3.57-3.47 (m, $1 \mathrm{H}, \beta-\mathrm{CH}_{2} \mathrm{Trp}$ ), $3.30-3.20(\mathrm{~m}$, $\left.1 \mathrm{H}, \beta-\mathrm{CH}_{2} \mathrm{Trp}\right) .{ }^{13} \mathrm{C}$ NMR (126 MHz, DMSO- $\left.d_{6}\right) \delta: 170.4,166.8$, $166.7,142.2$, 139.0, 137.4, 134.2, 133.7, 133.5, 132.7, 132.1, 132.0, $131.8,131.5,130.8,129.8,129.3,128.9,128.0,124.8,121.8,117.3$, 108.6, 54.2, 26.2. HRMS $\left(\mathrm{ESI}^{+}\right) \mathrm{m} / z$ : calcd for $\mathrm{C}_{35} \mathrm{H}_{25} \mathrm{~N}_{2} \mathrm{O}_{14} \mathrm{Cl}$ 732.09943; found 732.09918.

Biological Methods. Antiviral Activity against HIV. The MT-4 cells used for the anti-HIV assays were a kind gift from Dr. L. Montagnier (formerly at the Pasteur Institute, Paris, France) and cultured in Roswell Park Memorial Institute (RPMI)-1640 medium (Invitrogen, Merelbeke, Belgium) supplemented with $10 \%$ fetal calf serum (FCS) (Hyclone, Perbio Science, Aalst, Belgium) and 1\% Lglutamine (Invitrogen). The HIV-1 strain NL4-3 was obtained from 
the AIDS Research and Reference Reagent Program (Division of AIDS, NIAID, NIH) and cultured in MT-4 cells. The virus stock was stored at $-80{ }^{\circ} \mathrm{C}$.

The compounds were evaluated for their inhibitory activity against HIV-1 (NL4.3) and HIV-2 (ROD) infection in MT-4 cell cultures, as have been described in detail earlier. ${ }^{64}$ Briefly, MT-4 cells $(50 \mu \mathrm{L}, 1 \times$ $10^{6}$ cells $/ \mathrm{mL}$ ) were preincubated for $30 \mathrm{~min}$ at $37^{\circ} \mathrm{C}$ with the test compounds $(100 \mu \mathrm{L})$ in a 96-well plate. Next, the cell-line adapted HIV strains (NL4.3 and ROD) were added according to the 50\% tissue culture infectious dose (TCID50) of the viral stock. After 5 days, the cytopathic effect (CPE) was scored microscopically and the anti-HIV-1 activity ( $50 \%$ effective concentration, $\mathrm{EC}_{50}$ ) of each compound was calculated using a colorimetric method based on the in situ reduction of 3-(4,5-dimethylthiazol-2-yl)-5-(3-carboxymethoxyphenyl)-2-(4-sulfophenyl)- $2 \mathrm{H}$-tetrazolium (MTS) ${ }^{65}$ according to the manufacturer's instructions (Promega, Leiden, The Netherlands). Assays are performed by adding a small amount of a solution that contains tetrazolium compound MTS and an electron-coupling reagent (phenazine ethosulfate; PES), directly to culture wells, incubating for 1-4 h and then recording the absorbance at $490 \mathrm{~nm}$ (A490) with a 96-well plate reader. The quantity of the formazan product, as measured by the amount of $490 \mathrm{~nm}$ absorbance, is directly proportional to the number of living cells in culture. Cytotoxicity in MT-4 cells was measured after 5 days using the MTS/PES method. ${ }^{64,65}$ Data are the mean \pm SD of at least three independent experiments.

PBMCs from healthy donors (obtained from the Red Cross Blood Transfusion Center, Leuven, Belgium) were resuspended in Roswell Park Memorial Institute (RPMI) 1640 medium supplemented with $10 \% \mathrm{FBS}$ and $2 \mathrm{mM}$ L-glutamine. The next day, cells were stimulated with phytohemagglutinin (PHA) at $2 \mu \mathrm{g} / \mathrm{mL}$ (Sigma, Bornem, Belgium) for 3 days at $37{ }^{\circ} \mathrm{C}$. The PHA-stimulated blasts were then seeded at $0.5 \times 10^{6}$ cells per well into a 48 -well plate containing various concentrations of the compound in cell culture medium containing 10\% FCS and IL-2 (25 U/mL; R\&D Systems Europe, Abingdon, U.K.). The virus stocks were added at a final dose of 250 pg p24 HIV-1 Ag. The cell supernatant was collected on day 10 and HIV-1 core Ag in the culture supernatant was analyzed by a specific p24 Ag enzyme-linked immunosorbent assay (ELISA) kit (PerkinElmer, Zaventem, Belgium). Mock-infected cell cultures exposed to the different drug concentrations were examined for cell viability by the MTS/PES method.

Surface Plasmon Resonance (SPR) Analysis (HIV). The SPR technique was used to determine the binding of 33 (AL-518) and AL471 (as positive control) to gp120, which was immobilized on a CM5 chip in a Biacore T200 instrument (GE Healthcare, Uppsala, Sweden). gp120 immobilization was performed using a standard amine coupling procedure. Briefly, the surface was activated using a 7 min injection of 1-ethyl-3-(3-dimethylaminopropyl)carbodiimide (EDC)/N-hydroxysuccinimide (NHS) 1:1. Following this, recombinant HIV-1 IIIB glycoprotein gp120 (ImmunoDx, Woburn, Massachusetts), diluted in $\mathrm{pH} 4$ acetate immobilization buffer to 10 $\mu \mathrm{g} / \mathrm{mL}$, was injected on the surface for $420 \mathrm{~s}$, resulting in a response of \pm 1400 RU. Afterward, the surface was deactivated by injecting 1.0 $\mathrm{M}$ ethanolamine- $\mathrm{HCl} \mathrm{pH} 8.5$ for $7 \mathrm{~min}$. Finally, the surface was regenerated with $12 \mathrm{~s}$ injections of $50 \mathrm{mM} \mathrm{NaOH}$ and $\mathrm{HCl} \mathrm{pH} 1.5$ at $30 \mu \mathrm{L} / \mathrm{min}$ to remove any unbound ligand. All injections were performed with an injection speed of $5 \mu \mathrm{L} / \mathrm{min}$ excluding the surface regeneration step $(30 \mu \mathrm{L} / \mathrm{min})$. Interaction studies were performed at $25{ }^{\circ} \mathrm{C}$ in HBS-P+ (10 mM N-(2-hydroxyethyl)piperazine- $N^{\prime}$ ethanesulfonic acid (HEPES), $150 \mathrm{mM} \mathrm{NaCl}, 0.05 \%$ surfactant P20; pH 7.4) supplemented with 5\% DMSO. AL-471 and 33 (AL518) were diluted in twofold dilution steps with concentrations ranging from 0.1 to $12.5 \mu \mathrm{M}$. The analytes were injected using multiple cycle kinetics for $2 \mathrm{~min}$ at a flow rate of $30 \mu \mathrm{L} / \mathrm{min}$, and the dissociation was measured for $4 \mathrm{~min}$. A $12 \mathrm{~s}$ injection of $50 \mathrm{mM}$ $\mathrm{NaOH}$ was used to regenerate the surface. Several buffer blanks were included for double referencing. Apparent binding kinetics $\left(K_{\mathrm{D}}, k_{\mathrm{a}}, k_{\mathrm{d}}\right)$ were derived after fitting the experimental data to the 1:1 Langmuir binding model in Biacore T200 Evaluation Software 3.1. Solvent correction was applied to compensate for the DMSO bulk effects. The experiments were performed in quadruplicates.

Additional SPR experiments were now performed to analyze inhibition of viral gp120 binding to the host cell's CD4 receptor by 33 (AL-518) and the prototype AL-471. For this experiment, human histidine-tagged CD4 (Life Technologies Europe, Merelbeke, Belgium) was immobilized on a nitrilotriacetic acid (NTA) chip. Immobilization was performed using a standard nickel chelation procedure. First, two channels of the chip (reference and analysis channel) were activated with 1 min injection of $0.5 \mathrm{mM} \mathrm{NiCl}_{2}$ at a flow rate of $10 \mu \mathrm{L} / \mathrm{min}$. Afterward, $2 \mu \mathrm{g} / \mathrm{mL}$ His-CD4 was immobilized onto the second channel (analysis channel) by a $60 \mathrm{~s}$ injection at a flow rate of $10 \mu \mathrm{L} / \mathrm{min}$. Next, a mixture of $25 \mathrm{nM}$ gp 120 with either 33 (AL-518) or AL-471 at varying concentrations was injected for 2 min over both channels. The compounds mixed with gp120 were used in a concentration range between 10000 and $10 \mathrm{nM}$ using fourfold dilution steps. Finally, the chip surface was regenerated using three $1 \mathrm{~min}$ injections of $350 \mathrm{mM}$ ethylenediaminetetracetic acid (EDTA) at a flow rate of $30 \mu \mathrm{L} / \mathrm{min}$. Binding percentages were calculated using the maximum response at the end of each injection and comparing it to the pure $25 \mathrm{nM}$ gp 120 injection. The experiments were performed in triplicate.

Antiviral Activity against EV-A71. The EV-A71 BrCr laboratoryadapted strain and clinical isolates representative of $B$ genogroup (B2 sub-genogroup, 11316; B5 sub-genogroup, TW/70902/08) and C genogroup (C2 sub-genogroup, H08300 461\#812; C4 sub-genogroup, TW/1956/05) were used at a low multiplicity of infection (MOI) in a standardized cell-based antiviral assay. Briefly, rhabdomyosarcoma $(\mathrm{RD})$ cells were seeded in a 96-well plate. The day after, a serial dilution of the compounds and the virus inoculum was added to the cells. The assay plates were incubated at $37^{\circ} \mathrm{C}, 5 \%$ $\mathrm{CO}_{2}$ with virus inoculum and compounds until full virus-induced cell death was observed in the untreated, infected controls (3 days postinfection). Subsequently, the antiviral effect was quantified using a colorimetric readout with 3-(4,5-dimethylthiazol-2-yl)-5-(3-carboxymethoxyphenyl)-2-(4-sulfophenyl)-2H-tetrazolium/phenazine methosulfate (MTS/PMS method), and the concentration of the compound at which $50 \%$ inhibition of virus-induced cell death was observed $\left(\mathrm{EC}_{50}\right)$ was calculated from the antiviral dose-response curves. A similar assay setup was used to determine the adverse effect of the compound on uninfected, treated cells for calculation of $\mathrm{CC}_{50}$ (concentration of the compound that reduces the overall cell health by $50 \%$ as determined by the MTS/PMS method). The selectivity index (SI) was calculated as the ratio of $\mathrm{CC}_{50}$ to $\mathrm{EC}_{50}$.

Computational Methods. In Silico Model Building of Ligands and HIV-1 Env Glycoproteins. The molecular graphics program $\mathrm{PyMOL}^{66}$ was employed for molecular editing, visualization, and figure preparation. The structure of the HIV-1 envelope protein (Env, UniProt code Q2N0S6), consisting of a trimer of fully cleaved gp120 and gp41 subunits, was taken from the PG16-Env complex deposited in the Protein Data Bank with accession code 6ULC. ${ }^{25}$ Each protein fragment was conveniently "capped" by acetyl (ACE) and N-methyl amide (NME) groups at N- and C-termini, respectively. Disulfide bonds were explicitly defined for the following cysteine pairs: 54-74, 119-205, 126-196, 131-157, 218-247, 228-239, 296-331, 378445 , and $385-418$ in gp120 and 598-604 in gp41. Replacing the standard ASN name for asparagine by the N-linked NLN residue in AMBER allowed attachment of a conserved glycan profile compatible with a "consensus glycosylation target", 67 namely, (i) Man GlcNAc $_{2}$ at glycosylation positions 156 and 332; $\mathrm{Man}_{3} \mathrm{GlcNAc}_{2}$ at glycosylation positions 88, 134, 138, 160, 197, and 276; $\mathrm{Man}_{1} \mathrm{GlcNAc}_{2}$ at 295, 301, $339,363,386$, and 411 in gp120; and (ii) GlcNAc 2 at 262 and 448 in gp120 and 611, 625, and 637 in gp41 (residue numbers are standardized using the reference HIV-1 strain, HXB2). The Carbohydrate and Glycoprotein Builders publicly available at the GLYCAM-Web server (https://dev.glycam.org/) were used for the generation of free $\mathrm{Man}_{9} \mathrm{GlCNAc}_{2}-\mathrm{OMe}$ and for interactive protein glycosylation, respectively. The AMBER-compatible GLYCAM06 force field ${ }^{68}$ was used for the carbohydrates. 
For completion, the membrane-proximal external region and the transmembrane (TM) segments of gp41 (residues 664-683) were taken from $\mathrm{PDB}$ entry $6 \mathrm{E} 8 \mathrm{~W}^{69}$ and embedded in a cholesterol-rich lipid bilayer using the CHARMM-GUI Membrane Builder pipeline. ${ }^{70}$ The outer layer consisted of 54 sphingomyelin (PSM, 18:1/16:0), 26 dipalmitoylphosphatidylcholine (DPPC, 16:0/16:0), and 90 cholesterol molecules; the inner layer was composed of 25 dipalmitoylphosphoserine (DPPS, 16:0/16:0) and 112 cholesterol molecules, interspersed with 44 units of the plasmalogen or ether lipid DPPE-E (16:0/16:0), in accordance with data from the HIV lipidome. ${ }^{71}$ The AMBER lipid17 and lipid17_ext force fields ${ }^{72,73}$ were used for lipids already in the database; consistent parameters and point charges were derived for PSM and DPPE-E fragments using antechamber in AMBER18. The central positioning of the TM segment with respect to the membrane normal was unbiasedly performed by the PPM utility implemented in the Orientations of Proteins in Membranes (OPM) database (http://opm.phar.umich.edu). ${ }^{74}$ About 100000 TIP3P water molecules were then placed along the $Z$-axis on both sides of the lipid bilayer to solvate the protein as well as the lipid head groups. Finally, electroneutrality was achieved and the bulk ion concentration was set at $0.15 \mathrm{M}$ by adding 462 potassium and 272 chloride ions.

Molecular Dynamics Simulations. For more efficient conformational sampling of 33 (AL-518) and identification of possible modes of interaction with the glycan shield of the HIV Env protein, the molecule was immersed in a truncated octahedral box of TIP3P water molecules, which also contained counterions and two molecules of $\mathrm{Man}_{9} \mathrm{GlcNAc}_{2}$-OMe. System coordinates were first relaxed by performing 25000 steps of steepest descent followed by 100000 steps of conjugate gradient energy minimization. The resulting configurations were then used as input for molecular dynamics (MD) simulations at $300 \mathrm{~K}$ and $1 \mathrm{~atm}$ using the AMBER18 implementation of the pmemd.cuda engine, ${ }^{75}$ essentially as described earlier for AL385. ${ }^{38} \mathrm{~A}$ weak harmonic restraint of $1 \mathrm{kcal} \cdot \mathrm{mol}^{-1} \cdot \AA^{-2}$ was initially imposed on the $\operatorname{Trp} \mathrm{C} \alpha$ atoms to promote water and counterion equilibration. Thereafter, trajectory snapshots over 300 ns of unrestrained MD simulations were saved every $0.5 \mathrm{~ns}$ for further analysis and movie preparation.

The MD simulations of the membrane-embedded glycosylated gp 120:gp41 trimer and the complex of the external region with 33 (AL-518) were run for $400 \mathrm{~ns}$ essentially as described before for other membrane receptors ${ }^{76,77}$ and $\mathrm{EV71} \mathrm{VP} 1{ }^{38}$ respectively.

\section{ASSOCIATED CONTENT}

\section{(s) Supporting Information}

The Supporting Information is available free of charge at https://pubs.acs.org/doi/10.1021/acs.jmedchem.1c00315.

${ }^{1} \mathrm{H} \mathrm{NMR},{ }^{13} \mathrm{C}$ NMR, and MS spectra of the synthesized compounds together with HPLC of representative compounds and two-dimensional spectra of tripodal 14 and tetrapodal 21 and 32 (PDF)

Interactions between the isophthaloyl moieties attached to $\mathrm{C} 2$ and $\mathrm{C} 7$ positions of Trp in 33 (AL-518) and four molecules of a model Man $\alpha_{1-2}$ Man disaccharide used as a simplified version of the oligomannose-type $N$-glycans present in gp120 and gp41 (Movie S1) (MPG)

Protein surface coverage provided by the highly mobile glycan "cloud" around gp120 and gp41 in a membraneembedded HIV-1 Env protein (Movie S2) (MPG) Clustering of solutions and alternative accommodations of 33 (AL-518) interacting with the glycans surrounding the V3 loop of gp120 throughout the unrestrained molecular dynamics simulations (200-400 ns postequilibration period) in the presence of explicit water molecules and counterions (Movie S3) (MPG)

Cartoon representation of an HIV-1 glycosylated gp120:gp41 dimer in complex with a two-domain fragment of the human CD4 receptor (Movie S4) (MPG)

Molecular formula strings of the novel synthesized compounds (CSV)

\section{AUTHOR INFORMATION}

\section{Corresponding Authors}

Federico Gago - Área de Farmacología, Departamento de Ciencias Biomédicas y Unidad Asociada IQM-UAH, Universidad de Alcalá, E-28805 Alcalá de Henares, Madrid, Spain; ○ orcid.org/0000-0002-3071-4878; Phone: (+34) 918854 514; Email: federico.gago@uah.es

Ana San-Félix - Instituto de Química Médica (IQM-CSIC), E-28006 Madrid, Spain; 10 orcid.org/0000-0003-42717598; Phone: (+34) 912587 689; Email: anarosa@ iqm.csic.es

\section{Authors}

Olaia Martí-Marí - Instituto de Química Médica (IQMCSIC), E-28006 Madrid, Spain

Belén Martínez-Gualda - Instituto de Química Médica (IQM-CSIC), E-28006 Madrid, Spain; Present Address: Medicinal Chemistry, Rega Institute for Medical Research, KU Leuven, B-3000 Leuven, Belgium.

Sofía de la Puente-Secades - Instituto de Química Médica (IQM-CSIC), E-28006 Madrid, Spain; Present Address: Institute for Molecular Cardiovascular Research (IMCAR), RWTH Aachen University, University Hospital Aachen, 52074 Aachen, Germany

Alberto Mills - Área de Farmacología, Departamento de Ciencias Biomédicas y Unidad Asociada IQM-UAH, Universidad de Alcalá, E-28805 Alcalá de Henares, Madrid, Spain

Ernesto Quesada - Instituto de Química Médica (IQMCSIC), E-28006 Madrid, Spain

Rana Abdelnabi - Laboratory of Virology and Chemotherapy, Department of Microbiology and Immunology, Rega Institute for Medical Research, University of Leuven, B-3000 Leuven, Belgium

Liang Sun - Laboratory of Virology and Chemotherapy, Department of Microbiology and Immunology, Rega Institute for Medical Research, University of Leuven, B-3000 Leuven, Belgium

Arnaud Boonen - Laboratory of Virology and Chemotherapy, Department of Microbiology and Immunology, Rega Institute for Medical Research, University of Leuven, B-3000 Leuven, Belgium

Sam Noppen - Laboratory of Virology and Chemotherapy, Department of Microbiology and Immunology, Rega Institute for Medical Research, University of Leuven, B-3000 Leuven, Belgium

Johan Neyts - Laboratory of Virology and Chemotherapy, Department of Microbiology and Immunology, Rega Institute for Medical Research, University of Leuven, B-3000 Leuven, Belgium

Dominique Schols - Laboratory of Virology and Chemotherapy, Department of Microbiology and Immunology, Rega Institute for Medical Research, University of Leuven, B-3000 Leuven, Belgium

María-José Camarasa - Instituto de Química Médica (IQMCSIC), E-28006 Madrid, Spain; 다이.org/0000-00024978-6468 
Complete contact information is available at:

https://pubs.acs.org/10.1021/acs.jmedchem.1c00315

\section{Author Contributions}

Research design: M.-J.C., E.Q., and A.S.-F. Synthetic chemistry: O.M.-M., B.M.-G., and S.d.1.P.-S. Biological evaluations: R.A., L.S., A.B., and S.N. Computational studies: A.M. and F.G. Performed data analysis and supervised experiments: D.S., J.N., and S.N. Wrote or contributed to the writing of the manuscript: O.M.-M., F.G., and A.S.-F. All authors have given approval to the final version of the manuscript.

\section{Notes}

The authors declare no competing financial interest.

\section{ACKNOWLEDGMENTS}

This work was supported by the Spanish MICINN (Projects PID2019-104070RB-C21 and PID2019-104070RB-C22), the Spanish Agencia Estatal Consejo Superior de Investigaciones Científicas (CSIC, Projects CSIC-PIE-201980E100 and CSICPIE-201980E028), "The Centers of Excellence" of the KU Leuven (EF-05/15 and PF-10/18), EU FP7 (FP7/2007-2013) Project EUVIRNA (Grant 408 Agreement 264286), EU FP7 SILVER (Contract HEALTH-F3-2010-260644), a grant from the Belgian Interuniversity Attraction Poles (IAP) Phase VIIP7/45 (BELVIR), and the EU FP7 Industry-Academia Partnerships and Pathways Project AIROPICO. Spanish MEC/MINECO is also acknowledged for grants to B.M.-G. and O.M.-M. and the China Scholarship Council (CSC) (Grant 201403250056) for a grant to L.S. The authors also thank Charlotte Vanderheydt, Evelyne Van Kerckhove, Caroline Collard, Kim Donchers, and Sandra Claes for help with the processing of the antiviral data. This work has been awarded the Janssen (XVIII call) and Esteve (XIX call) prizes within the "Prizes for Young Researchers of the Spanish Society of Medicinal Chemistry (SEQT)."

\section{DEDICATION}

${ }^{\dagger}$ This work is dedicated to Prof. Jan Balzarini (KU Leuven, Belgium), on the occasion of his retirement, in recognition of his constant encouragement and exemplary dedication to virology.

\section{ABBREVIATIONS}

AIDS, acquired immune deficiency syndrome; bnAbs, broadly neutralizing antibodies; CCR5, chemokine receptor type 5; CXCR4, C-X-C $\alpha$-chemokine receptor type 4; DIPEA, $N, N$ diisopropylethylamine; DMF, dimethylformamide; DS-5000, dextran sulfate-5000; EV71, enterovirus 71; EV-A71, enterovirus 71 genogroup A; FCS, fetal calf serum; HHA, Hippeastrum hybrid agglutinin; HATU, hexafluorophosphate azabenzotriazole tetramethyl uronium; HIV, human immunodeficiency virus; mAb, monoclonal antibody; MTS, 3-(4,5dimethylthiazol-2-yl)-5-(3-carboxymethoxy-phenyl)-2-(4-sulfophenyl)-2H-tetrazolium; NTA, nitrilotriacetic acid; PBMCs, peripheral blood mononuclear cells; PES, phenazine ethosulfate; PHA, phytohemagglutinin; PRM-A, pradimicin A; SMR, Suzuki-Miyaura reaction; SPR, surface plasmon resonance; TFA, trifluoroacetic acid; Trp, tryptophan

\section{REFERENCES}

(1) Roux, K.; Taylor, K. AIDS virus envelope spike structure. Curr. Opin. Struct. Biol. 2007, 17, 244-252.

(2) Harrison, S. C. Viral membrane fusion. Nat. Struct. Mol. Biol. 2008, 15, 690-698.

(3) Adamson, C. S.; Freed, E. O. Human immunodeficiency virus type 1 assembly, release, and maturation. Adv. Pharmacol. 2007, 55, 347-387.

(4) Kwong, P. D.; Wyatt, R.; Robinson, J.; Sweet, R. W.; Sodroski, J.; Hendrickson, W. A. Structure of an HIV gp120 envelope glycoprotein in complex with the CD4 receptor and a neutralizing antibody. Nature 1998, 393, 648-659.

(5) Esté, J. A. Inhibition of HIV Entry. In Antiviral Drug Strategies, Methods and Principles in Medicinal Chemistry; De Clercq, E., Ed.; Wiley-VCH Verlag GmbH \& Co KGaA: Weinheim, Germany, 2011; Vol. 50, pp 29-50.

(6) Kang, Y.; Guo, J.; Chen, Z. Closing the door to human immunodeficiency virus. Protein Cell 2013, 4, 86-102.

(7) Klasse, P. J. The molecular basis of HIV entry. Cell. Microbiol. 2012, 14, 1183-1192.

(8) Lu, L.; Fei, Y.; Lifeng, C.; Asim, K. D.; Shibo, J. Development of small-molecule HIV entry inhibitors specifically targeting gp120 or gp41. Curr. Top. Med. Chem. 2016, 16, 1074-1090.

(9) Micewicz, E. D.; Ruchala, P. Inhibitors of HIV-1 entry. Curr. Pharm. Des. 2013, 19, 1784-1799.

(10) Wilen, C. B.; Tilton, J. C.; Doms, R. W. Molecular mechanisms of HIV entry. Adv. Exp. Med. Biol. 2012, 726, 223-242.

(11) Ding, X.; Zhu, Y.; Chong, H.; Cui, S.; Zhang, X.; He, J.; Wang, $\mathrm{X}$.; He, Y. Structural and functional characterization of HIV-1 cell fusion inhibitor T20. AIDS 2018, 33, 1-11.

(12) Woollard, S. M.; Kanmogne, G. D. Maraviroc: a review of its use in HIV infection and beyond. Drug Des., Dev. Ther. 2015, 9, $5447-5468$.

(13) Markham, A. Ibalizumab: First global approval. Drugs 2018, 78, $781-785$.

(14) Sheikh, V.; Murray, J. S.; Sherwat, A. Ibalizumab in multidrugresistant HIV: accepting uncertainty. N. Engl. J. Med. 2018, 379, 605607.

(15) Markham, A. Fostemsavir: First Approval. Drugs 2020, 80, 1485-1490.

(16) Meanwell, N. A.; Krystal, M. R.; Nowicka-Sans, B.; Langley, D. R.; Conlon, D. A.; Eastgate, M. D.; Grasela, D. M.; Timmins, P.; Wang, T.; Kadow, J. F. Inhibitors of HIV-1 attachment: the discovery and development of Temsavir and its prodrug Fostemsavir. J. Med. Chem. 2018, 61, 62-80.

(17) Caffrey, M. HIV envelope: challenges and opportunities for development of entry inhibitors. Trends Microbiol. 2011, 19, 191-197.

(18) Wyatt, R; Sodroski, J. The HIV-1 envelope glycoproteins: fusogens, antigens and immunogens. Science 1998, 280, 1884-1888.

(19) Zolla-Pazner, S.; Cohen, S. S.; Boyd, D.; Kong, X. P.; Seaman, M.; Nussenzweig, M.; Klein, F.; Overbaugh, J.; Totrov, M. Structure/ function studies involving the V3 region of the HIV-1 envelope delineate multiple factors that affect neutralization sensitivity. J. Virol. 2016, 90, 636-649.

(20) de Jong, J. J.; Goudsmit, J.; Keulen, W.; Klaver, B.; Krone, W.; Tersmette, M.; de Ronde, A. Human immunodeficiency virus type 1 clones chimeric for the envelope V3 domain differ in syncytium formation and replication capacity. J. Virol. 1992, 66, 757-765.

(21) Bhattacharyya, D.; Brooks, B. R.; Callahan, L. Positioning of positively charged residues in the V3 loop correlates with HIV type 1 syncytium-inducing phenotype. AIDS Res. Hum. Retroviruses 1996, 12, 83-90.

(22) Javaherian, K.; Langlois, A. J.; McDanal, C.; Ross, K. L.; Eckler, L. I.; Jellis, C. L.; Profy, A. T.; Rushche, J. R.; Bolognesi, D. P.; Putney, S. D. Principal neutralizing domain of the human immunodeficiency virus type 1 envelope protein. Proc. Natl. Acad. Sci. U.S.A. 1989, 86, 6768-6772.

(23) Fera, D.; Lee, M. S.; Wiehe, K.; Meyerhoff, R. R.; Piai, A.; Bonsignori, M.; Aussedat, B.; Walkowicz, W. E.; Ton, T.; Zhou, J. O.; 
Danishefsky, S.; Haynes, B. F.; Harrison, S. C. HIV envelope V3 region mimic embodies key features of a broadly neutralizing antibody lineage epitope. Nat. Commun. 2018, 9, No. 1111.

(24) Kong, L.; Lee, J. H.; Doores, K. J.; Murin, C. D.; Julien, J.-P.; McBride, R.; Liu, Y.; Marozsan, A.; Cupo, A.; Klasse, P-J.; Hoffenberg, S.; Caulfield, M.; King, C. R.; Hua, Y.; Le, K. M.; Khayat, R.; Deller, M. C.; Clayton, T.; Tien, H.; Feizi, T.; Sanders, R. W.; Paulson, J. C.; Moore, J. P.; Stanfield, R. L.; Burton, D. R.; Ward1, A. B.; Wilson, I. A. Supersite of immune vulnerability on the glycosylated face of HIV1 envelope glycoprotein gp120. Nat. Struct. Mol. Biol. 2013, 20, 796805.

(25) Pan, J.; Peng, H.; Chen, B.; Harrison, S. C. Cryo-EM structure of full-length HIV-1 Env bound with the Fab of antibody PG16. J. Mol. Biol. 2020, 432, 1158-1168.

(26) Rivero-Buceta, E.; Doyagüez, E. G.; Colomer, I.; Quesada, E.; Mathys, L.; Noppen, S.; Liekens, S.; Camarasa, M.-J.; Pérez-Pérez, M.J.; Balzarini, J.; San-Félix, A. Tryptophan dendrimers that inhibit HIV replication, prevent virus entry and bind to the HIV envelope glycoproteins gp 120 and gp41. Eur. J. Med. Chem. 2015, 106, 34-43.

(27) Rivero-Buceta, E.; Sun, L.; Martínez-Gualda, B.; Doyagüez, E. G.; Donkers, K.; Quesada, E.; Camarasa, M.-J.; Delang, L.; San-Félix, A.; Neyts, J.; Leyssen, P. Optimization of a class of tryptophan dendrimers that inhibit HIV replication leads to a selective, specific and low-nanomolar inhibitor of clinical isolates of enterovirus A71. Antimicrob. Agents Chemother. 2016, 60, 5064-5067.

(28) Nadel, S. Hand, foot, mouth, brainstem and heart disease resulting from enterovirus 71. Crit. Care Med. 2013, 41, 1821-1822.

(29) Solomon, T.; Lewthwaite, P.; Perera, D.; Cardosa, M. J.; McMinn, P.; Ooi, M. H. Virology, epidemiology, pathogenesis and control of enterovirus 71. Lancet Infect. Dis. 2010, 10, 778-790.

(30) McMinn, P. C. An overview of the evolution of enterovirus 71 and its clinical and public health significance. FEMS Microbiol. Rev. 2002, 26, 91-107.

(31) Chang, L.-Y.; Huang, L.-M.; Gau, S. S.-F.; Wu, Y.-Y.; Hsia, S.H.; Fan, T.-Y.; Lin, K.-L.; Huang, Y.-C.; Lu, C.-Y.; Lin, T.-Y. Neurodevelopment and cognition in children after enterovirus 71 infection. N. Engl. J. Med. 2007, 356, 1226-1234.

(32) Chen, C. Y.; Chang, Y. C.; Huang, C. C.; Lui, C. C.; Lee, K. W.; Huang, S. C. Acute flaccid paralysis in infants and young children with enterovirus 71 infection: MR imaging findings and clinical correlates. AJNR Am. J. Neuroradiol. 2001, 22, 200-205.

(33) Chan, Y.-F.; Sam, I.-C.; Wee, K.-L.; Abubakar, S. Enterovirus 71 in Malaysia: A decade later. Neurol. Asia 2011, 16, 1-15.

(34) ProMED-mail post Human enterovirus 2016 Spain: (CT) http://promedmail.org/post/20160524.4242904 for earlier report on this enterovirus outbreak in Catalonia, Spain.

(35) European Centre for Disease Prevention and Control [ECDC]. Week 31, 29 July-4 August, 2018. https://ecdc.europa.eu/en/ search?s=enterovirus + A71.

(36) Lin, J.-Y.; Kung, Y.-A.; Shih, S.-R. Antivirals and vaccines for enterovirus A71. J. Biomed. Sci. 2019, 26, No. 65.

(37) Baggen, J.; Thibaut, H. J.; Strating, J. R. P. M.; van Kuppeveld, F. J. M. The life cycle of non-polio enteroviruses and how to target it. Nat. Rev. Microbiol. 2018, 16, 368-381.

(38) Martínez-Gualda, B.; Sun, L.; Martí-Marí, O.; Noppen, S.; Abdelnabi, R.; Bator, C. M.; Quesada, E.; Delang, L.; Mirabelli, C.; Lee, H.; Schols, D.; Neyts, J.; Hafenstein, S.; Camarasa, M. J.; Gago, F.; San-Félix, A. Scaffold simplification strategy leads to a novel generation of dual Human Immunodeficiency virus and enterovirusA71 entry inhibitors. J. Med. Chem. 2020, 63, 349-358.

(39) Fikatas, A.; Vervaeke, P.; Martínez-Gualda, B.; Martí-Marí, O.; Noppen, S.; Meyen, E.; Camarasa, M. J.; San-Félix, A.; Pannecouque, C.; Schols, D. Tryptophan trimers and tetramers inhibit dengue and Zika virus replication by interfering with viral attachment processes. Antimicrob. Agents Chemother. 2020, 64, No. e02130-19.

(40) Noisier, A. F. M.; Brimble, M. A. C-H Functionalization in the Synthesis of Amino Acids and Peptides. Chem. Rev. 2014, 114, 87758806.
(41) Loach, R. P.; Fenton, O. S.; Amaike, K.; Siegel, D. S.; Ozkal, E.; Movassaghi, M. C7-derivatization of C3-alkylindoles including tryptophans and tryptamines. J. Org. Chem. 2014, 79, 11254-11263.

(42) Shen, F.; Tyagarajan, S.; Perera, D.; Krska, S. W.; Maligres, P. E.; Smith, M. R., III; Maleczka, R. E., Jr. Bismuth acetate as a catalyst for the sequential protodeboronation of di- and triborylated indoles. Org. Lett. 2016, 18, 1554-1557.

(43) Paul, S.; Chotana, G. A.; Hlmes, D.; Reichle, R.; Maleczka, R.; Smith, M. Ir-catalyzed functionalization of 2-substituted indoles at the 7-position: nitrogen-directed aromatic borylation. J. Am. Chem. Soc. 2006, 128, 15552-15553.

(44) Miyaura, N.; Suzuki, A. Palladium-Catalyzed Cross-Coupling Reactions of Organoboron Compounds. Chem. Rev. 1995, 95, 24572483.

(45) Ornelas, C.; Broichhagen, J.; Weck, M. Strain-promoted alkyne azide cycloaddition for the functionalization of poly(amide)-based dendrons and dendrimers. J. Am. Chem. Soc. 2010, 132, 3923-3931.

(46) Flores, A.; Camarasa, M. J.; Pérez-Pérez, M. J.; San-Félix, A.; Balzarini, J.; Quesada, E. Multivalent agents containing 1-substituted 2,3,4-trihydroxyphenyl moieties as novel synthetic polyphenols directed against HIV-1. Org. Biomol. Chem. 2014, 12, 5278-5294.

(47) Newkome, G. R.; Weis, C. D. 6,6-bis(carboxy-2-oxabutyl)-4,8dioxaundecane-1,11-dicarboxylic acid. Org. Prep. Proced. Int. 1996, 28, $242-244$.

(48) Eastabrook, A. S.; Sperry, J. Iridium-catalyzed triborylation of 3subsituted indoles. Aust. J. Med. 2015, 1810-1814.

(49) Tijsma, A.; Franco, D.; Tucker, S.; Hilgenfeld, R.; Froeyen, M.; Leyssen, P.; Neyts, J. The capsid binder vapendavir and the novel protease inhibitor SG85 inhibit enterovirus 71 replication. Antimicrob. Agents Chemother. 2014, 58, 6990-6992.

(50) Andries, K.; Dewindt, B.; Snoeks, J.; Willebrords, R.; Van Eemeren, K.; Stokbroekx, R.; Janssen, P. A. J. In vitro activity of pirodavir ( $\mathrm{R}$ 77975), a substituted phenoxy pyridazinamine with broad-spectrum antipicornaviral activity. Antimicrob. Agents Chemother. 1992, 36, 100-107.

(51) Yamayoshi, S.; Yamashita, Y.; Li, J.; Hanagata, N.; Minowa, T.; Takemura, T.; Koike, S. Scavenger receptor B2 is a celular receptor for enterovirus. Nat. Med. 2009, 15, 798-801.

(52) Sun, L.; Lee, H.; Thibaut, H. J.; Lanko, K.; Rivero-Buceta, E.; Bator, C.; Martinez-Gualda, B.; Dallmeiera, K.; Delang, L.; Leyssen, P.; Gago, F.; San-Félix, A.; Hafenstein, S.; Mirabelli, C.; Neyts, J. Viral engagement with host (co-)receptors blocked by a novel class of tryptophan dendrimers that targets the 5-fold-axis of the enterovirusA71 capsid. PLoS Pathog. 2019, 15, No. e1007760.

(53) Baba, M.; Pauwels, R.; Balzarini, J.; Arnout, J.; Desmyter, J.; De Clercq, E. Mechanism of inhibitory effect of dextran sulfate and heparin on replication of human immunodeficiency virus in vitro. Proc. Natl. Acad. Sci. U.S.A. 1988, 85, 6132-6136.

(54) Balzarini, J.; Laethem, K. V.; Daelemans, D.; Hatse, S.; Bugatti, A.; Rusnati, M.; Igarashi, Y.; Oki, T.; Schols, D. Pradimicin A, a carbohydrate-binding nonpeptidic lead compound for treatment of infections with viruses with highly glycosylated envelopes, such as human Immunodeficiency virus. J. Virol. 2007, 81, 362-373.

(55) Donzella, G. A.; Schols, D.; Lin, S. W.; Esté, J. A.; Nagashima, K. A.; Maddon, P. J.; Allaway, G. P.; Sakmar, T. P.; Henson, G.; De Clerq, E.; Moore, J. P. AMD3100, a small molecule inhibitor of HIV-1 entry via the CXCR4 co-receptor. Nat. Med. 1998, 4, 72-77.

(56) Murin, C. D.; Julien, J.-P.; Sok, D.; Stanfield, R. L.; Khayat, R.; Cupo, A.; Moore, J. P.; Burton, D. R.; Wilson, I. A.; Ward, A. B. Structure of 2G12Fab2 in complex with soluble and fully glycosylated HIV-1 Env by negative-stain single-particle electron microscopy. J. Virol. 2014, 88, 10177-10188.

(57) Stanfield, R. L.; Gorny, M. K.; Williams, C.; Zolla-Pazner, S.; Wilson, I. A. Structural rationale for the broad neutralization of HIV-1 by human monoclonal antibody 447-52D. Structure 2004, 12, 193204.

(58) Zolla-Pazner, S.; Zhong, P.; Revesz, K.; Volsky, B.; Williams, C.; Nyambi, P.; Gorny, K. M. The cross-clade neutralizing activity of a 
human monoclonal antibody is determined by the GPGR V3 motif of HIV type 1. AIDS Res. Hum. Retroviruses 2004, 20, 1254-1258.

(59) Wyatt, R.; Thali, M.; Tilley, S.; Pinter, A.; Posner, M.; Ho, D.; Robinson, J.; Sodroski, J. Relationship of the human immunodeficiency virus type 1 gp120 third variable loop to a component of the CD4 binding site in the fourth conserved region. J. Virol. 1992, 69977004.

(60) Balzarini, J.; Hatse, S.; Vermeire, K.; Princen, K.; Aquaro, S.; Perno, C.-F.; De Clercq, E.; Egberink, H.; Vanden Mooter, G.; Peumans, W.; Van Damme, E.; Schols, D. Mannose-specific plant lectins from the Amaryllidaceae family qualify as efficient microbicides for prevention of human immunodeficiency virus infection. Antimicrob. Agents Chemother. 2004, 3858-3870.

(61) Jiang, X.; Burke, V.; Totrov, M.; Williams, C.; Cardozo, T.; Gorny, M. K.; Zolla-Pazner, S.; Kong, X.-P. Conserved structural elements in the V3 crown of HIV-1 gp120. Nat. Struct. Mol. Biol. 2010, 17, 955-961.

(62) Behrens, A.-J.; Vasiljevic, S.; Pritchard, L. K.; Harvey, D. J.; Andev, R. S.; Krumm, S. A.; Struwe, W. B.; Cupo, A.; Kumar, A.; Zitzmann, N.; Seabright, G. E.; Kramer, H. B.; Spencer, D. I. R.; Royle, L.; Lee, J. H.; Klasse, P. J.; Burton, D. R.; Wilson, I. A.; Ward, A. B.; Sanders, R. W.; Moore, J. P.; Doores, K. J.; Crispin, M. Composition and antigenic effects of individual glycan sites of a trimeric HIV-1 envelope glycoprotein. Cell Rep. 2016, 14, 26952706.

(63) Kumari, M.; Balaji, P. V.; Sunoj, R. B. Quantification of binding affinities of essential sugars with a tryptophan analogue and the ubiquitous role of $\mathrm{C}-\mathrm{H} \cdots \pi$ interactions. Phys. Chem. Chem. Phys. 2011, 13, 6517-6530.

(64) Vermeire, K.; Princen, K.; Hatse, S.; De Clercq, E.; Dey, K.; Bell, T. W.; Schols, D. CADA, a novel CD4-targeted HIV inhibitor, is synergistic with various anti-HIV drugs in vitro. AIDS 2004, 18, 2115-2125.

(65) Pauwels, R.; Balzarini, J.; Baba, M.; Snoeck, R.; Schols, D.; Herdewijn, P.; Desmyter, J.; De Clercq, E. Rapid and automated tetrazolium-based colorimetric assay for the detection of anti-HIV compounds. J. Virol. Methods 1988, 20, 309-321.

(66) DeLano, W. L. The PyMOL Molecular Graphics System, version 1.8; Schrödinger, LLC: New York, 2013.

(67) Go, E. P.; Ding, H.; Zhang, S.; Ringe, R. P.; Nicely, N.; Hua, D.; Steinbock, R. T.; Golabek, M.; Alin, J.; Alam, S. M.; Cupo, A.; Haynes, B. F.; Kappes, J. C.; Moore, J. P.; Sodroski, J. G.; Desaire, H. Glycosylation benchmark profile for HIV-1 envelope glycoprotein production based on eleven Env trimers. J. Virol. 2017, 91, No. e02428-16.

(68) Kirschner, K. N.; Yongye, A. B.; Tschampel, S. M.; GonzalezOuteirino, J.; Daniels, C. R.; Foley, B. L.; Woods, R. J. GLYCAM06: a generalizable biomolecular force field. Carbohydrates. J. Comput. Chem. 2008, 29, 622-655.

(69) Fu, Q.; Shaik, M. M.; Cai, Y.; Ghantous, F.; Piai, A.; Peng, H.; Rits-Volloch, S.; Liu, Z.; Harrison, S. C.; Seaman, M. S.; Chen, B.; Chou, J. J. Structure of the membrane proximal external region of HIV-1 envelope glycoprotein. Proc. Natl. Acad. Sci. U.S.A. 2018, 115, E8892-E8899.

(70) Lee, J.; Patel, D. S.; Stahle, J.; Park, S. J.; Kern, N. R.; Kim, S.; Lee, J.; Cheng, X.; Valvano, M. A.; Holst, O.; Knirel, Y. A.; Qi, Y.; Jo, S.; Klauda, J. B.; Widmalm, G.; Im, W. CHARMM-GUI Membrane Builder for complex biological membrane simulations with glycolipids and lipoglycans. J. Chem. Theory Comput. 2019, 15, 775-786.

(71) Brugger, B.; Glass, B.; Haberkant, P.; Leibrecht, I.; Wieland, F. T.; Krausslich, H. G. The HIV lipidome: a raft with an unusual composition. Proc. Natl. Acad. Sci. U.S.A. 2006, 103, 2641-2646.

(72) Dickson, C. J.; Madej, B. D.; Skjevik, A. A.; Betz, R. M.; Teigen, K.; Gould, I. R.; Walker, R. C. Lipid14: The AMBER lipid force field. J. Chem. Theory Comput. 2014, 10, 865-879.

(73) Madej, B. D.; Gould, I. R.; Walker, R. C. A parameterization of cholesterol for mixed lipid bilayer simulation within the AMBER Lipid14 force field. J. Phys. Chem. B 2015, 119, 12424-12435.
(74) Lomize, M. A.; Pogozheva, I. D.; Joo, H.; Mosberg, H. I.; Lomize, A. L. OPM database and PPM web server: resources for positioning of proteins in membranes. Nucleic Acids Res. 2012, 40, D370-D376.

(75) Salomon-Ferrer, R.; Götz, A. W.; Poole, D.; Le Grand, S.; Walker, R. C. Routine microsecond molecular dynamics simulations with AMBER on GPUs. 2. Explicit solvent Particle Mesh Ewald. J. Chem. Theory Comput. 2013, 9, 3878-3888.

(76) Herrera-Arozamena, C.; Estrada-Valencia, M.; Pérez, C.; Lagartera, L.; Morales-García, J. A.; Pérez-Castillo, A.; FrancoGonzález, J. F.; Michalska, P.; Duarte, P.; León, R.; López, M. G.; Mills, A.; Gago, F.; García-Yagüe, A. J.; Fernández-Ginés, R.; Cuadrado, A.; Rodríguez-Franco, M. I. Tuning melatonin receptor subtype selectivity in oxadiazolone-based analogues: Discovery of QR2 ligands and NRF2 activators with neurogenic properties. Eur. J. Med. Chem. 2020, 190, No. 112090.

(77) Perona, A.; Ros, M. P.; Mills, A.; Morreale, A.; Gago, F. Distinct binding of cetirizine enantiomers to human serum albumin and the human histamine receptor $\mathrm{H}_{1}$. J. Comput.-Aided Mol. Des. 2020, 34, 1045-1062.

\section{NOTE ADDED AFTER ASAP PUBLICATION}

This article originally published with an error in the TOC graphic. The TOC was replaced and the article reposted on July 7, 2021. 